UNIVERSIDADE DE SÃO PAULO

FACULDADE DE FILOSOFIA, LETRAS E CIÊNCIAS HUMANAS

DEPARTAMENTO DE LETRAS ORIENTAIS

PROGRAMA DE PÓS-GRADUAÇÃO EM LITERATURA E CULTURA RUSSA

MÁRCIA MARIA OLIVEIRA FREITAS

A Mulher do Subsolo em Niétotchka Niezvânova de F. M. Dostoiévski

Versão Corrigida

São Paulo

2018 
UNIVERSIDADE DE SÃO PAULO

FACULDADE DE FILOSOFIA, LETRAS E CIÊNCIAS HUMANAS

DEPARTAMENTO DE LETRAS ORIENTAIS

PROGRAMA DE PÓS-GRADUAÇÃO EM LITERATURA E CULTURA RUSSA

\title{
A Mulher do Subsolo em Niétotchka Niezvânova de F. M. Dostoiévski
}

\author{
Versão Corrigida
}

Márcia Maria Oliveira Freitas

Dissertação apresentada ao Programa de Pós-Graduação em Literatura e Cultura Russa do Departamento de Letras Orientais da Faculdade de Filosofia, Letras e Ciências Humanas da Universidade de São Paulo como requisito para obtenção do título de Mestre em Literatura e Cultura Russa. Pesquisa desenvolvida com apoio da CAPES.

De acordo,

Orientador: Professor Dr. Mário Ramos Francisco Júnior

São Paulo 
Autorizo a reprodução e divulgação total ou parcial deste trabalho, por qualquer meio convencional ou eletrôtico, para fins de estudo e pesquisa, desde que citada a fonte.

Faculdade de Flosofia, Letras e Ciências Humanas da Universidade de São Panlo

\author{
(2) \\ Freitas, Márcia Maria Oliveira \\ F862m A Duiher do Subaolo on M16totehka N1arvinova da $\nabla$. \\ orientador Nário Ranos Branciaco Jinior. - Sto \\ Daulo, 2018. \\ $103 \mathrm{f}$. \\ D1asertaç\$o (Mentrado) - Faculdada de F11oeofia, \\ Latran a C1ancias Hunanas da tulvera1dade de Sao \\ Daulo. Dapartananto de Letrag Or1enta1s. Area de \\ concantraçalo: Literatura a Cultura Pusaa. \\ 1. Reprenentaçao da Mulner. 2. Subeolo. 3. S6culo \\ XIX. 4. Litaratura Ruana. 5. Doato16vak1. I. \\ Branc1aco Júnior, Nário Ramon, orfant. Ir. Título.
}




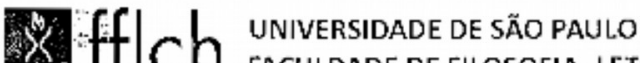

FACULDADE DE FILOSOFIA, LETRAS E CIÊNCIAS HUMANAS

\section{ENTREGA DO EXEMPLAR CORRIGIDO DA DISSERTACุÃO/TESE \\ Termo de Ciência e Concordância do (a) orientador (a)}

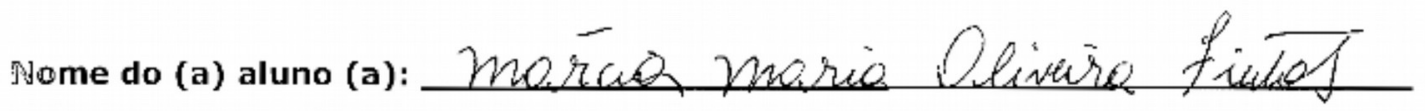
ata da defesa: 30101,2019

Nome do Prof. (a) orientador (a): Morot Ramos froncise femes

Nos termos da legislação vigente, declaro ESTAR CIENTE do conteúdo deste EXEMPLAR CORRIGIDO elaborado em atenção às sugestões dos membros da comissão Julgadora na sessão de defesa do trabalho, manifestando-me plenamente favorável ao seu encaminhamento e publicação no Portal Digital de Teses da USP.

São Paulo, $01 / 04 / 2010$

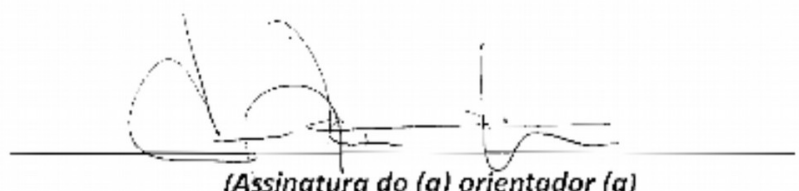




\section{FOLHA DE APROVAÇÃO}

Márcia Maria Oliveira Freitas

A mulher do Subsolo em Niétotchka Niezvânova de F. M. Dostoiévski

Dissertação de Mestrado apresentada ao Programa de PósGraduação em Literatura e Cultura Russa do Departamento de Letras Orientais da Faculdade de Filosofia, Letras e Ciências Humanas da Universidade de São Paulo.

Aprovado em:

Banca examinadora:

Professor Dr. Mário Ramos Francisco Júnior

Faculdade de Filosofia, Letras e Ciências Humanas

Universidade de São Paulo

Orientador

Prof. Dr.

Instituição:

Assinatura

Prof. Dr.

Instituição: Assinatura

Prof. Dr.

Instituição: Assinatura 


\section{AGRADECIMENTOS}

Ao meu orientador Mário Francisco Ramos, pela orientação.

À CAPES, pelo fomento à presente pesquisa.

À querida professora Elena Vássina, pelo aprendizado da língua russa, pelo carinho e respeito durante todo esse percurso e, principalmente, pelos elogios diários que contribuíram na minha formação em Literatura e Cultura Russa.

À querida Mariana Frank, pela ajuda com o texto em inglês.

Ao querido Leandro Hollanda, pela ajuda com a revisão e com o texto em inglês.

Aos funcionários do Departamento de Letras Orientais.

Aos queridos colegas da Universidade que ao longo do percurso apoiaram este trabalho, em especial Cássia Marconi, Mônica Alves Baptista, Giuliana Almeida, Wellington, Henrique Canary, Patrícia Lewis, Márcia Mura, Alexandre Rdash, Ingrid Lidyane da Silva, Renata Nakane e Guara. Aos funcionários dos Restaurantes Universitários.

Às queridas e amigas Léia de Almeida e Luciana Ramos Pereira, pela confiança no meu trabalho, pelo apoio diário e, principalmente, pela atenção dada nos momentos mais difíceis desta pesquisa. Aos queridos amigos Agnelo Bento Lino, Marcela, Daniela da Silva, Verônica e Lilian Sendretti, por tudo.

Às pessoas queridas não citadas aqui.

À minha família: Sheila Adriana da Cruz e Priscila Barreto da Cruz.

Esta dissertação é em memória de meus pais, Josias Oliveira Freitas e Aparecida Soares Oliveira Freitas, que tinham para si a arte de escrever como uma de suas práticas. 


\section{RESUMO}

Em 1849, Dostoiévski publica Niétotchka Niezvânova. No centro da narrativa temos uma mulher cujos fatos de sua vida (na infância) são trazidos à tona pelo seu próprio ponto de vista. Suas memórias, dadas as ambiguidades presentes, vão ao encontro de Memórias do Subsolo, publicada em 1864. Memórias, apesar de ser uma obra posterior de Dostoiévski em relação à Niétotchka Niezvânova, faz-nos pensar em muitos procedimentos literários e temas desenvolvidos que já fermentavam antes, de algum modo e com certas particularidades, nesta obra que será analisada aqui. Haverá um esforço em demonstrar como Niétotchka (uma mulher) fala do seu subsolo e como aquilo que é narrado em primeira pessoa, da maneira como é exposto a nós leitores, diz-nos muito sobre o verdadeiro caráter desta personagem feminina. O que nos leva, inevitavelmente, a uma questão fundamental na elaboração da personagem: a marginalização do ser humano, em seus diversos aspectos, que pretendemos discorrer ao longo da pesquisa apresentada aqui.

Palavras-chave: Subsolo, Representação da Mulher, Marginalização 


\begin{abstract}
In 1849, Dostoevsky publishes Netochka Nezvanova, which has the plot focused ona woman that has thefacts of her life (in childhood) brought outthrough her own point of view. Her memories, given the held ambiguities, go against Notes from Underground, which was published in 1864. Although it came out later than Netochka Nezvanova, Notes makes us recall many literary methods and handled themes which, in some extent, were latent in the book analysed here. It will be sought to demonstrate how Netochka (a woman) speaks out from her underground and howher first-person narrative, as it is exposed to us readers, says a lot about the true nature of this female character. It leads us, inevitably, to a fundamental pointin the creation of such a character: the many facets of human marginalisation, which we intend to discourse along this research.
\end{abstract}

Keywords: Underground, Women's representation, Marginalisation. 


\section{SUMÁRIO}

CONSIDERAÇÕES INICIAIS. 10

1 - A PERSONAGEM FEMININA NA DÉCADA DE 1840 NA OBRA DE DOSTOIÉVSKI.

2 - DAS AMBIGUIDADES AFETIVAS (E DISCURSIVAS) EM NIÉTOTCHKA

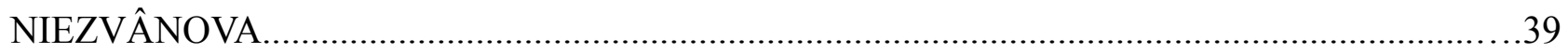

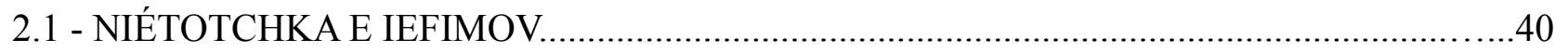

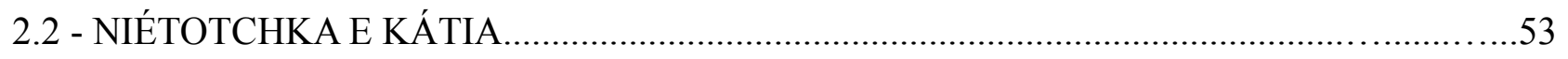

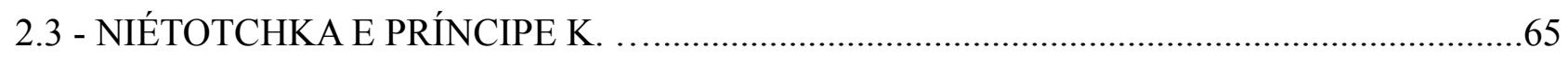

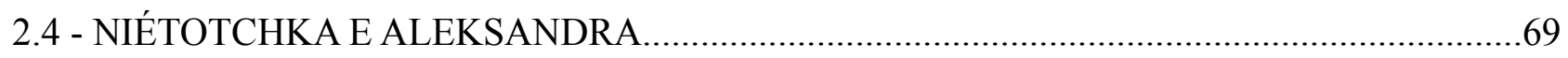

2.5 - NIÉTOTCHKA E LÁRIA (UM CAPÍTULO À PARTE) ..........................................................78

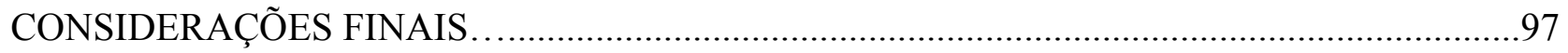

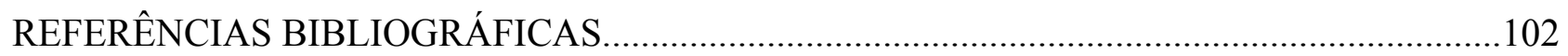




\section{Considerações Iniciais}

Niétotchka Niezvânova é uma obra da primeira fase literária de Dostoiévski e, também, a primeira ideia de um grande romance do autor russo ${ }^{1}$. Localizada em um momento crucial, de reviravolta espiritual em Dostoiévski, esta obra de transição entre dois períodos distintos da poética do grande prosador russo sentirá os prenúncios de certos procedimentos artísticos e, sobretudo, do processo de elaboração de certa personagem, que serão uma constante em sua prosa. Dostoiévski rompe com algumas velhas formas de representar o homem no início da sua carreira de escritor.

Pensemos em Gente Pobre, sua primeira obra, que lhe garantiu um lugar frente ao público leitor e aos críticos de sua época. Nela, ao colocar em cena os "homens comuns", o autor russo inova ao deslocar o acento dado a essas personagens. Assim, Dostoiévski, ao deslocar essas personagens marginalizadas da esfera do riso para a do trágico, rompe com o tratamento dado a essa classe de excluídos. Fazendo emergir, por meio de sua representação, a dignidade e humanidade dessas personagens sem importância, até então. Dostoiévski também inova na maneira como as mulheres surgirão em suas obras, mais humanizadas do que vemos em outras obras do período. Através de seus procedimentos artísticos, ele desloca o acento dado à representação da mulher, como verificaremos nesta análise.

No centro da obra temos uma mulher (Niétotchka) que fala de suas reminiscências da infância e do início de sua adolescência. Contudo, por meio de seu discurso e de suas relações ambíguas, a narradora deixa-nos entrever, em uma análise mais atenta, um caráter singular. Ou seja, com a maneira que a personagem feminina se nos apresenta, vislumbramos um esboço de uma personalidade que, mais a frente, Dostoiévski nomeará como a personagem do subsolo.

A presente análise procurará traçar um caminho, no qual poderemos demonstrar que Niétotchka é, por excelência, uma criatura do subsolo, ou melhor, um esboço da personalidade do subsolo. Primeiramente, faz-se necessário um estudo sobre a personagem feminina, ou seja, faz-se necessário um estudo sobre a representação da mulher na literatura. Pensando nessa representação do feminino, é importante dar atenção à maneira como outras personagens femininas serão elaboradas no primeiro momento da prosa de Dostoiévski, de maneira que possamos averiguar quais as semelhanças e dessemelhanças entre Niétotchka e suas outras personagens femininas.

E para demonstrar que Niétotchka é uma personagem do subsolo, procuraremos fazer uma comparação entre ela e outras personagens femininas do período, esclarecendo a questão da representação da mulher e a novidade na representação da narradora de Niétotchka Niezvânova. A novidade consiste no fato de que ela, Niétotchka, diferente das personagens femininas que também serão analisadas, mostrar-se-á singular em termos de elaboração, inevitavelmente se aproximando

1 Joseph Frank. Dostoiévski: As Sementes da Revolta, 1821-1849. São Paulo. Edusp, 2008. Ver p. 439. 
de personagens masculinas, no tocante ao grau de liberdade e, sobretudo, ao grau de legitimidade de fala em sua narrativa, seja na ordem da narração, ou da estruturação. Procedimento artístico este em Dostoiévski que dificilmente encontramos em outros escritores de sua época. Cabe salientar, ainda, que Niétotchka é a primeira e única personagem feminina dostoievskiana que narra a sua vida a partir do seu próprio ponto de vista.

No mesmo caminho, dada a singularidade da representação de Niétotchka, seguiremos em direção às ambiguidades discursivas e afetivas (que se notarão nas suas relações com o outro) para, finalmente, pôr luz sobre o seu caráter de subsolo. Em conjunto com essas questões que serão abordadas ao longo do percurso analítico, traremos algumas questões do momento histórico que se coadunam com o debate apresentado, como parte constitutiva. Para tais resultados, a depender do assunto tratado, traremos e discutiremos a fortuna crítica necessária. 


\section{A PERSONAGEM FEMININA NA DÉCADA DE 1840 NA OBRA DE DOSTOIÉVSKI}

Comparada a algumas personagens femininas do início das obras dostoievskianas, Niétotchka se apresenta com algumas particularidades que a diferem de outras personagens. Dentre as quais destaca-se o fato de ser a primeira mulher (ou menina, pensando aqui na sua infância que é narrada) a quem Dostoiévski permite direcionar a sua narrativa. Podemos ir até mais longe e afirmarmos que não somente será a narradora de sua própria história, ou melhor, aquela que narrará a partir do seu próprio ponto de vista entre as personagens femininas dessa primeira fase do autor russo, como também Niétotchka é a única personagem feminina nos romances de Dostoiévski que decididamente é a dona da palavra.

Em comparação a Varvara Dobrosiólova, personagem feminina da primeira obra de Dostoiévski Gente Pobre, que lhe rendeu grande acolhida pela crítica literária da época ${ }^{2}$, Niétotchka se afasta completamente da maneira como aquela foi elaborada pelo autor. Gente Pobre é um romance epistolar e foi publicado em 1846, dando início à carreira do escritor russo. Trata-se da história de amizade entre um pequeno funcionário, Makar Diévuchkin, e a órfã Varvara Dobrosiólova. A narrativa, que é estabelecida pela troca de cartas entre ambos, é marcada por uma forte relação de cumplicidade e amizade entre as personagens, que mesmo se encontrando em uma situação penosa diante das adversidades da vida miserável na qual viviam, vislumbra-se, ao mesmo tempo, a emergência de sentimentos elevados e de questionamentos sobre aquela realidade de então. A nobreza do caráter das personagens em situação tão miserável é colocada em cena neste primeiro romance de Dostoiévski.

Varienka, diferentemente de Niétotchka tem para si a infância como a melhor época de sua vida.

Minha infância foi a época mais feliz da minha vida.

(Dostoiévski: 2009, p. 33)

Um aspecto interessante surge quando Varienka passa a narrar fatos da sua infância, pelas cartas que troca com o personagem Makar Diévuchkin, é a sua relação com o campo.

E acho que teria sido muito feliz se me tivesse tocado morar no mesmo lugar, sem ter de sair do campo, ainda que por toda a minha vida... Tinha apenas doze anos ainda quando nos mudamos para Petersburgo. (Dostoiévski: 2009, p. 33)

2 Ver posfácio de Fátima Bianchi. In: Gente Pobre, 2009. P. 174. 
Nessas reminiscências de Varienka, podemos notar como a oposição entre campo e cidade já se faz presente nessa primeira obra de Dostoiévski. Se atentarmos pela maneira que surgem essas lembranças de Varienka, de maneira tão nostálgica, perceberemos como o seu estado de espírito é outro, de paz e harmonia, que se ajusta à natureza e aos seus semelhantes.

[...] Mas de manhã acordo fresca como uma florzinha. Olho pela janela: o campo estava todo crestado pela geada; a escarcha fina de outono pendia dos ramos nus; o lago estava coberto de gelo, fino como uma folha de papel; um vapor branco se levanta sobre o lago; os passarinhos gritam alegremente. O sol ilumina tudo em volta com seus raios brilhantes, e os raios partem o gelo fino como se fosse vidro. Há luz, claridade, alegria! No fogão, o fogo torna a crepitar; sentamo-nos todos junto do samovar, e o nosso cão preto, Polkan, tiritante do frio da noite, espreita-nos através da janela, abanando o rabo para nos saudar... Estamos todos tão satisfeitos e tão alegres!... Ah, que infância dourada foi a minha!... (Dostoiévski: 2009, p. 131-132)

Mas sua infância toma outra guinada quando a família de Varienka vai para Petersburgo. Nesse ponto, cria-se um contato entre ela e Niétotchka. As relações de Varienka com os pais, que até então eram harmoniosas, passam a se tornar hostis, criando um anticlímax familiar, ou seja, passam a se estranhar sob o mesmo teto, distanciando-se um do outro cada vez mais

[...] Às vezes venho do internato e só encontro rostos tão tristes; a mãezinha chorando em silêncio e o paizinho irritado. Começariam as reprimendas e recriminações. O paizinho se poria a dizer que não lhe proporciono nenhuma alegria, nenhum consolo; que por minha causa eles se privam dos últimos recursos e eu até agora não falo francês, em suma, descarregava todos os seus fracassos, todas as suas desditas, tudo, sempre em cima de mim e da mãezinha." (Dostoiévski: 2009) p.36

"As preocupações, os desgostos e a falta de sorte levaram o pobre paizinho ao limite do esgotamento: tornou-se desconfiado e bilioso; muitas vezes ficava à beira do desespero, começou a descuidar da saúde, apanhou um resfriado e, de repente, adoeceu, seu sofrimento não durou muito tempo e faleceu de maneira tão repentina, tão súbita, que todas nós, por alguns dias, ficamos aturdidas com o choque. A mãezinha estava como que entorpecida; cheguei a temer por seu juízo.(Dostoiévski: 2009, p. 37)

A cidade de São Petersburgo parece conotar algo de antinatural nas relações de seus habitantes, a sua própria fisionomia parece também pontuar esses desajustes sociais.

Como foi difícil habituar-me à nova vida! Chegamos a Petersburgo no outono. Quando deixamos o campo, o dia estava tão claro, quente, brilhante; a lida na roça estava chegando ao fim; as medas enormes de cereais já estavam amontoadas nas eiras cobertas e bandos estridentes de pássaros iam se glomerando; estava tudo tão claro e alegre, enquanto aqui, à nossa entrada na cidade, nos deparamos com chuva, lama, com a escarcha podre do outono, o mau tempo e uma multidão de rostos novos, desconhecidos, todos hostis, aborrecidos, zangados! (Dostoiévski: 2009, p.34) 
É esse mesmo estranhamento que se dá com Niétotchka no convívio com seus pais, claro que, aqui, com sentimentos outros em jogo, mas o efeito que a cidade causa no âmbito familiar é o mesmo.

Lembro-me de uma tarde, ao crepúsculo, tudo estava espalhado em desordem: as escovas, uns esfregões, nossos pratos de madeira, uma garrafa quebrada, e não sei mais o quê. Minha mãezinha, lembro-me, chorava, extremamente transtornada. Meu padrasto sentarase a um canto com o seu indefectível paletó esfarrapado. Respondeu-lhe algo em tom de escárnio, o que aumentou mais o furor de minha mãezinha. Escovas e pratos tornaram a voar pelos ares. Pus-me a gritar e, em prantos, corri para junto deles. (Dostoiévski: 2009, p. 36)

Natália Nunes acredita que a personagem "Varienhka é incaracterística, e quase só um pretexto para dar lugar à exibição do caráter do velho.”3 Parece ser um tanto forçoso acreditar que Varvara não tem um peso fundamental na primeira novela do jovem Dostoiévski. O próprio sobrenome da personagem (Dobrosiólova), que tem como raiz a palavra em russo "dobryi" que significa "bom", nos dá uma boa medida da sua importância na trama. Gente Pobre é uma narrativa das mazelas de uma parte da população que vive à margem da sociedade, porém, em meio àquela miséria que perpassa toda a narrativa, vemos na figura de Varienka e de Makar toda uma generosidade e bondade mútuas que ganham espaço na narrativa, devido ao bom caráter de ambas as personagens. E, sendo assim, Várvara foi parte substancial na intenção do autor russo.

A personagem Nástienka (Nastassia) de Noites Brancas, novela que despertou o interesse do público $^{4}$, parece ter um misto de senso de realidade e de sonho, comparada ao narrador desta novela. Noites Brancas é publicada em 1848. Traz como personagem principal um narrador sonhador que se encontra algumas noites com a personagem Nástienka e passa, a partir de então, a experimentar um misto de sonho e realidade, que pela primeira vez em sua vida se relaciona minimamente com o outro. Passando a ser, deste modo, esse breve período sob as noites brancas de São Petersburgo os momentos mais felizes e reais da existência desse solitário sonhador. Nástienka, porém, assoma mais realista.

\footnotetext{
- A que conclusão cheguei? Cheguei à conclusão de que é preciso começar tudo de novo, pois no final das contas concluí hoje que o senhor é ainda absolutamente desconhecido para mim, que ontem agi com criança, como uma menina, e, sem dúvida, o culpado de tudo foi o meu bom coração; ou seja, eu me exaltei, como sempre acaba acontecendo quando nos deixamos levar pelas emoções... (Dostoiévski: 2005, p. 27)
}

Sobre esse senso de realidade presente na personagem feminina de Noites Brancas, vale a observação de Nivaldo dos Santos, em seu posfácio de Noites Brancas, segundo a qual

3 Natália Nunes. "Novelas da Juventude" e "Prólogo Geral". In: Obras Completas, VI. Ed. Nova Aguilar, Rio de Janeiro, 1995. P. 126.

4 Pensemos, por exemplo, na adaptação cinematográfica de Noites Brancas de um dos maiores diretores do cinema italiano, Luchino Visconti. 
embora esteja igualmente coberta por um véu de romantismo, a moça parece ter um senso de vida prática mais aguçado do que o narrador, tanto que não hesita na hora de escolher entre seus dois pretendentes. Nástienka pode sem dúvida ser tomada como uma 'sonhadora', mas, talvez em razão de sua simplicidade, ela está mais próxima do mundo real, o que a torna capaz de ajustar-se minimamente ao ritmo da vida cotidiana. Seus sonhos não vão muito além do mundo à sua volta, ela não tem grandes pretensões; na verdade, deseja apenas casar-se com o homem que ama. ${ }^{5}$

Nástienka parece não ter desvios de seu caráter como notaremos em Niétotchka, ao contrário, durante toda a narrativa, quer dizer, do que temos acesso por meio da lembrança do narrador, aquela é sempre guiada pelos bons pensamentos por força de seu "bom coração". O que se sobressai de maneira mais contida é sua mente fantasiosa

\begin{abstract}
- Um sonhador? Perdão, mas como não saber? Eu mesma sou uma sonhadora! Às vezes, sentada ao lado da avó, que coisas não me passam pela cabeça! Bem, daí começo a sonhar e imagino até que...bem, que estou casando com um príncipe chinês... Mas às vezes é tão bom sonhar! ... (Dostoiévski: 2005, p. 29)
\end{abstract}

\title{
Para Nunes,
}

de todas as heroínas femininas apresentadas na obra da juventude, Nástienka é a mais humana, a mais veridicamente mulher. A sua falsa inconstância, exprimindo o seu ardente desejo de amar e ser amada, de ter um objeto sobre o qual extravase toda a sua ternura, é uma característica real da maior parte das almas femininas. ${ }^{6}$

Mais adiante em seu trabalho, Nunes argumenta a respeito de Nástienka que

não é propriamente um temperamento de mulher que Dostoiévski nos apresenta aqui, quer-nos antes parecer que o genial escritor nos quis antes apresentar o fenômeno de "transposição" que se operou na alma dessa mulher enamorada, pois o seu coração transbordante de um amor que esperava oferecer ao homem que aguardava e que entretanto não vinha, não se contém, tem necessidade de um objeto visível e sensível, de outro ser que lhe dê a ilusão de que o escutam, que seja como que um alvo concreto sobre o qual possa incidir a luz da sua ternura. ${ }^{7}$

Posto isso, que Nástienka representa a personagem feminina na obra da juventude de Dostoiévski como a "mais humana", não sabemos como confirmar, dado o fato de que o ser

5 Posfácio de Noites Brancas. Tradução e Posfácio de Nivaldo dos Santos, 2005. P. 86.

6 Natália Nunes. "Novelas da Juventude" e "Prólogo Geral". In: Obras Completas, VI. Ed. Nova Aguilar, Rio de Janeiro, 1995. p. 143.

7 Idem, p. 640. 
humano tem as suas múltiplas facetas, e, definir o que é "mais humano" nas obras dostoievskianas, torna-se, então, uma tarefa bem difícil. É certo que Nástienka tem um senso de realidade que lhe permite viver de algo que caiba na sua realidade, e não somente de sonhos.

Em A Senhoria, vemos uma característica da personagem feminina Katierina que muito se assemelha com Niétotchka, ou seja, Katierina também não tem uma boa relação com a mãe. $A$ Senhoria é uma obra de 1847 , que não foi bem recebida por parte da crítica ${ }^{8}$. No centro da ação temos um narrador sonhador, Ordínov, que vê sua vida transtornada ao encontrar a personagem Katierina, cujos segredos de seu passado atraem o narrador como também lhe causam certa repulsa. Passado este que na narrativa é simbolizado pela figura da personagem Múrin, que mantém com Katierina uma relação não menos misteriosa.

Acontece que, em $A$ Senhoria, essa relação de ódio entre mãe e filha se configura de maneira distinta: é a mãe de Katierina que nutre esse sentimento de ódio pela filha, diferentemente de Niétotchka que nutre esse sentimento pela própria mãe.

[...] Como ela, minha mãezinha, chorou nesse momento... "eu mesma lhe direi que comerciantes eram esses que estiveram aqui e atrás de que mercadoria vieram... E vou lhe dizer de quem você é filha, sua bastarda! De agora em diante você não é mais minha filha, é uma víbora! Você é minha maldita criação! ... (Dostoiévski: 2006, p.71)

Chama a atenção no excerto acima não somente a rudeza das palavras da mãe de Katierina, como também aquilo que fica sugestivo por meio de suas palavras, como, por exemplo, a palavra "bastarda". Bianchi, no posfácio de A Senhoria, quando analisa o personagem Múrin, com quem Katierina vive e mantém uma relação um tanto indefinida e sugestiva na novela, afirma que

a verdade sobre Múrin não se esgota aí. Há uma pontinha de mistério que permanece até o fim envolvendo sua figura. Quando Katierina conta a Ordínov sua triste história, como morreram seus pais e ela se amigou com o assassino deles, que a enfeitiçou e adquiriu sobre ela um misterioso poder, a jovem parece guardar um segredo terrível, que lhe oprime profundamente a alma: pelo que tudo leva a crer, Múrin é o seu verdadeiro pai. ${ }^{9}$

Tanto Niétotchka quanto Katierina competem com suas respectivas mães pelo amor do pai, ou melhor, por essa figura paternal, ainda que em circunstâncias particulares, envolvendo cada uma das personagens.

Joseph Frank, ao analisar a personagem Katierina, argumenta que

com a personagem de Ekaterina, Dostoiévski aborda pela primeira vez a psicologia do

8 Ver posfácio de Bianchi em A Senhoria. P. 124.

9 Posfácio de A Senhoria. Tradução e Posfácio de Fátima Bianchi, 2006. P. 135. 
masoquismo e começa a explorar a ideia do "prazer" sutil e patológico que se pode extrair da autodilaceração e da autopunição. Ekaterina é uma vítima de Múrin e de todas as forças obscuras que ele representa; mas é também vítima da sua incapacidade de dominar o "prazer" que extrai da sua própria escravidão e degradação. ${ }^{10}$

Ainda que toda a narrativa de $A$ senhoria esteja ligada à personagem Katierina ${ }^{11}$, vemos que, de todo modo, não é ela quem narra a sua própria história, diferentemente de Niétotchka, como foi observado acima, que narra a partir do seu próprio ponto de vista e não por intermédio de outro narrador.

Quem chama a atenção para algumas particularidades de Katierina é Natália Nunes, observando que "Ekatierina, a moça enfeitiçada pelos sortilégios mágicos do bruxo, é também uma figura quase fantástica." 12 A autora prossegue afirmando ainda que

no entanto,'A Dona da Casa' não é um escrito 'fantástico', mas antes formalmente simbólico. Se o leitor meditar, há de verificar que o maravilhoso foi introduzido somente na medida em que se tornava necessário para definir a personalidade fantasista de Ekatierina. No final, o leitor chegará à conclusão de que o velho Múrin não é um feiticeiro, mas é antes um homem inteligente e hábil no estudo da psicologia do próximo. ${ }^{13}$

Pensando ainda na dimensão simbólica da personagem na obra, Nunes afirma que Ekatierina é "o símbolo da fraca e ingênua humanidade." 14

Quanto à questão levantada por Nunes de ser Katierina um símbolo da fraqueza humana, são interessantes as observações de Bianchi em relação a esse aspecto na obra. A autora acredita que “ao mostrar Katierina como um 'coração fraco', Dostoiévski não faz senão apresentar uma situação corrente na sociedade, em que os fortes deste mundo tomam para si a 'responsabilidade' pelos fracos." ${ }^{15}$ Mais adiante Bianchi pontua que

\footnotetext{
Dostoiévski coloca Katierina como uma 'filha da natureza' para mostrar que o que parece natural, a 'responsabilidade', a subjugação dos fracos pelos fortes, não é uma coisa natural, mas cultural, que foi socialmente construída, à revelia. E com isso ele mostra, também, o quanto é moralmente abjeto o empreendimento de moldar a mente e a vida de um ser humano em direção a um determinado fim. Não é à toa que Múrin aparece na novela como sinônimo de cinismo, como a
}

10 Joseph Frank. Dostoiévski As Sementes da Revolta 1821-1849. Ed. Edusp, 2008. P. 432.

11 Idem, p. 433.

12 Natália Nunes. "Novelas da Juventude" e "Prólogo Geral". In: Obras Completas, VI. Ed. Nova Aguilar, Rio de Janeiro, 1995. P. 419.

13 Idem. Ibidem.

14 Idem, p. 420.

15 Fátima Bianchi. O Domínio do Homem pelo Homem na Novela A Senhoria, de Dostoiévski. Revista Rus, v. 2 , nº 2 , 2013. P. 49. 
própria face do disfarce, e seu segredo seja o segredo da hipocrisia. ${ }^{16}$

Bianchi traz uma informação sobre a personalidade de Katierina que nos faz pensar em quanto ela se afasta de Niétotchka. A autora argumenta que

com sua astúcia, Múrin fora eliminando em sua imaginação aquilo que ela [Katierina] sabe ser a verdade, fato após fato. E o conhecimento que ela consegue ter de si mesma consiste apenas em um acúmulo de fragmentos de informações arbitrariamente abstraídos, mas que jamais a levarão à verdadeira compreensão da sua real condição. Condicionada pela situação objetiva, a sua capacidade de percepção, de conceber alternativas possíveis para a sua vida, logo alcança seus limites naturais, pois a modelagem do homem pelo homem, do indivíduo pela sociedade, pelo meio, aparece nessa novela de uma forma simbólica contundente. ${ }^{17}$

Nesse sentido, pensando nas observações acima de Bianchi, Katierina se distingue de Niétotchka, uma vez que aquela não tem consciência de sua situação (alienada), ao contrário desta que tem plena consciência do mundo que a cerca e de suas próprias ambiguidades. Por exemplo, pensemos aqui na relação de Niétotchka com seu padrasto Iefimov. Vemos, em certo momento da narrativa, a consciência da narradora atentar para o fato de que seu pai se utilizava de mentiras e de cinismo para conseguir algo dela. Niétotchka tem consciência disto, vejamos

Ao mesmo tempo, era-me penoso ouvi-lo, via que suas palavras e carinhos eram insinceros, e tudo isso me deixou de certo modo abalada. (Dostoiévski: 2009, p. 64)

Niétotchka tem uma característica que a distancia dessas outras personagens femininas apresentadas acima: a sua relação com o leitor. Vale observar que esta característica é muito comum nos narradores masculinos de Dostoiévski, como, por exemplo, o narrador das Memórias do Subsolo. A narradora de Niétotchka Niezvânova possui uma característica muito peculiar na sua relação com o leitor, ou seja, há um cinismo por trás do seu discurso que visa ao mesmo tempo ganhar o leitor, com a sua história de abandono e de criatura humilhada e ofendida, e provocá-lo com as ambiguidades que constituem o seu caráter ambíguo. Segundo Bakhtin,

Aquela espécie de torturas morais a que Dostoiévski submete as suas personagens, visando a obter delas a palavra de sua autoconsciência, que chega aos seus últimos limites, permite dissolver todo o concreto e material, todo o estável e imutável, todo o externo e neutro na representação do indivíduo no campo da sua autoconsciência e da auto-enunciação. O herói do subsolo dá ouvido a cada palavra dos outros sobre si mesmo, olha-se aparentemente em todos os espelhos das consciências dos outros, conhece todas as possíveis refrações da sua

16 Idem, p. 50.

17 Idem, p. 49. 
imagem nessas consciências; conhece até sua definição objetiva, neutra tanto em relação à consciência alheia quanto à sua própria autoconsciência, leva em conta o ponto de vista de um terceiro. Sabe que lhe cabe a última palavra. A sua autoconsciência vive de sua inconclusibilidade. ${ }^{18}$

Niétotchka, em sua confissão (tomamos aqui de empréstimo uma expressão de Bakhtin), assim como o homem do subsolo, busca em alguns momentos nos contrariar, antecipando a palavra do outro, com a qual também entra em polêmica interior.

E quanto mais me ligava a meu pai, com tanta maior intensidade odiava a minha pobre mãe. Até hoje, a lembrança de tudo isso tortura-me profunda e amargamente.

Mas, como podia nascer em mim semelhante crueldade contra um ser eternamente sofredor, como era minha mãezinha? Somente agora compreendo a sua existência sofrida e não posso lembrar aquela mártir, sem sentir doer-me o coração.

Já naquele tempo sentia revoltar-se em mim a consciência, e notava muitas vezes com sofrimento a minha injustiça em relação a minha mãe. (Dostoiévski: 2009, pp. 39,42e 43)

O que chama a atenção, nestes excertos selecionados acima, é a capacidade de Niétotchka de se contradizer no mesmo ato em que afirma algo, ou seja, ela muda de tom repentinamente, como acontece com o narrador do subsolo. Nos dois primeiros trechos Niétotchka nos conta como no passado chegava a ter pensamentos e sentimentos negativos em relação a sua mãe, e que só agora, no presente, percebia toda aquela crueldade contra a mãe, mas logo em seguida, no último trecho, ela muda completamente o tom e afirma que "já naquele tempo" tinha a consciência da sua injustiça contra a mãe. Ou seja, ela joga o tempo todo com o leitor, antecipa a réplica do outro e responde a ela contrariando-o.

Nessa sequência de sua narrativa, é isto que a narradora nos mostra. Primeiro faz o leitor se apiedar com a história com a mãe, ainda mais com os adjetivos como "pobre mãe" e até "mártir", uma vez que para o leitor eram ações sem consciência, devido a pouca idade e etc. Mas quando percebe que já suscitou a piedade no leitor, ela nega aquilo que havia afirmado anteriormente, dizendo que sim, que tinha consciência. Contrariando, deste modo, a expectativa do leitor.

Essa questão temporal, que nas reminiscências pode ter um valor significativo, como é o caso aqui da confissão de Niétotchka, explica esta autoconsciência da narradora, que é inconclusa também, usando aqui as considerações de Bakhtin, uma vez que há uma espécie de gradação ao recordar fatos do passado que parecem fazer emergir também gradualmente a consciência de Niétotchka.

Por exemplo, estas expressões temporais ("Até hoje", "Somente agora" e "Já naquele tempo") nos dizem algo sobre o discurso que está sendo construído. Talvez possamos pensar que essa inconclusibilidade presente no discurso de Niétotchka explique em parte a maneira como 
Dostoiévski termina o romance. E analogamente ao discurso infinito do homem do subsolo, Bakhtin afirma:

\begin{abstract}
Mas é precisamente por isso que Dostoiévski termina a sua obra de maneira tão orgânica e tão adequada ao herói, e termina justamente inserindo a tendência à infinidade interna, colocada nas memórias do seu herói: "mas chega; não quero mais escrever "do Subsolo"... Sem dúvida, ainda não terminam aqui as "memórias" deste paradoxalista. Ele não se conteve e as continuou. Mas parece-nos que se pode fazer ponto final aqui mesmo. ${ }^{19}$
\end{abstract}

Podemos observar nas personagens femininas apontadas algum tipo de submissão, diferentemente de Niétotchka. É exemplar uma das cenas do romance, na qual vemos um confronto de Niétotchka com Piotr, marido de Aleksandra. Piotr vê a narradora com uma carta nas mãos e tira daí conclusões precipitadas, acreditando que Niétotchka possui um amante com o qual se corresponde por cartas. A partir desse instante a narrativa toma um rumo que fica mais difícil para o leitor saber qual será o desfecho final e as consequências desse fato. Mais adiante falaremos de maneira mais detida sobre a cena, mas vejamos a tensão gerada e, sobretudo, a atitude de Niétotchka ao enfrentar Piotr.

[...]Lembro-me daquele instante, pareço sofrê-lo novamente, tal a intensidade com que se gravou na minha memória.

Tinha nas mãos uma carta e um livro aberto; o meu rosto estava inundado de lágrimas. De repente, estremeci de susto: ressoara sobre mim uma voz conhecida. No mesmo instante, senti que alguém me arrancava a carta das mãos. Soltei um grito e olhei para trás: junto de mim estava Piotr Aleksândrovitch. Agarrou-me a mão e detinha-me à força no lugar; com a mão direita, aproximava a carta da luz e esforçava-se por decifrar as primeiras linhas... Pus-me a gritar $[\ldots]$ Eu perdia a cabeça...

Um instante depois, lancei-me na direção dele, quase não sabendo o que fazia, e arranqueilhe a carta das mãos. (Dostoiévski: 2009, p. 198)

O que se destaca nessa cena é essencialmente a postura de enfrentamento da narradora. Ela não se deixa intimidar e recupera novamente a carta, em uma clara atitude de insubmissão. Nota-se igualmente a questão da individualidade da personagem que se sobressai. Não verificamos essa postura de enfrentamento nas outras personagens femininas (referidas acima) desse primeiro período das obras dostoievskianas.

Um bom exemplo de submissão é Varvara. Na cena em que o seu violador aparece, repentinamente, em seu apartamento, no momento em que se encontrava sozinha e sem a sua protetora, a personagem é mostrada para nós leitores completamente enfraquecida e se submete ao seu algoz sem nenhuma relutância. A tal ponto que, o seu violador decide casar-se com ela e a mesma aceita por não ter forças para enfrentá-lo e, sobretudo, por não ter condições materiais para

19 Idem, p. 238. 
se manter, submetendo-se, então, a um casamento que não lhe trará nenhuma felicidade. O casamento de Varienka surge na narrativa como uma metáfora (por assim dizer) da prostituição. Bianchi chama a atenção para o fato da submissão feminina e afirma que

Dostoiévski, aliás, em seus artigos e romances, sempre denunciou a imoralidade que, em sua opinião, constitui esse tipo de casamento, uma "venda do corpo, que se realiza em nome da moral e da submissão, pelo menos tão imoral e vergonhoso como qualquer outro tipo de venda de corpo. ${ }^{20}$

Katierina, desde muito nova, une-se a um homem que se vale de muitos artifícios para seduzila. Embora seja por ela que Ordínov e Múrin competem, vemos uma mulher submissa a seus desejos por um homem com o qual não consegue romper, mesmo diante da possibilidade de um novo amor. Nastienka, por seu lado, com toda aquela simplicidade, também se submete aos homens. Por exemplo, ela espera durante um ano aquele a quem ama, a narrativa toda é trabalhada em cima dessa espera.

Podemos pensar que a diferença essencial entre Niétotchka e as personagens femininas discutidas, aqui, resida exatamente no fato de ela ser a primeira narradora da sua própria história. E, sendo assim, não passa pela visão de outro, ou seja, de um homem (na figura de um narrador em terceira pessoa), como acontece às demais personagens femininas. Nesse sentido, Niétotchka rompe com a construção da personalidade feminina até então submetida à visão idealizadora do homem.

Ainda que tenha sido construída a personagem por um escritor, ou seja, por um homem (depois falaremos mais sobre esse ponto), é sabido que Dostoiévski sempre procurou dar voz às suas personagens, dotá-las com suas próprias verdades. Quem atenta para esse método artístico do autor russo é Bianchi, em seu trabalho sobre a novela Uma Criatura Dócil, observando que

\footnotetext{
o que se destaca, então, como elemento extremamente significativo no sistema estrutural da novela é a posição do autor diante do objeto a ser representado, que deposita inteira confiança na capacidade do herói de exprimir sua verdade, mas apenas a sua própria, pois rejeita qualquer possibilidade de ele exprimir a verdade do outro, das outras personagens. ${ }^{21}$
}

Pensando, ainda, nesse ponto de vista da própria narradora que norteia a narrativa. Fugindo, deste modo, à velha forma de representar a mulher, parece-nos ser significativa a questão colocada por Mulvey, em seu trabalho sobre a construção do olhar masculino nas narrativas cinematográficas tradicionais, uma vez que a construção da perspectiva masculina nos parece presente na maioria das

20 Fátima Bianchi. O Tema da Submissão Feminina na Novela Uma Criatura Dócil. In: Caderno de Literatura e Cultura Russa, n. 2. Ateliê Editorial. São Paulo, 2008. Pp. 333-334.

21 Idem, p. 329. 
narrativas literárias tradicionais.

Segundo Mulvey, "ultrapassando o simples realce da qualidade de ser olhada, oferecida pela mulher, o cinema constrói o modo pelo qual ela deve ser olhada, dentro do próprio espetáculo." 22 Se atentarmos para como são construídas muitas personagens femininas na literatura, sobretudo no século XIX, veremos como é facilmente aplicável essa análise de Mulvey à narrativa literária. Por exemplo, pensemos no que está por trás dessa terceira pessoa, que ganha forma na figura do narrador. Ou melhor, qual é o ponto de vista que se esconde atrás dessa terceira pessoa?

Se voltarmos a algumas questões trabalhadas neste capítulo, sobre o papel fixo da mulher na sociedade, sobre o papel subserviente da mulher em relação ao homem e tantas outras questões, notaremos que não é difícil percebermos que a maioria das narrativas tradicionais são direcionadas por um ponto de vista masculino, na forma dos narradores em terceira pessoa. De tal maneira que, vislumbramos aquilo que, sem maiores avaliações, chamaríamos de um senso comum, isto é, de um ponto de vista cultural, no decorrer das narrativas, que têm como condutor um narrador em terceira pessoa

Porém, o que passa desapercebido é exatamente aquilo que fundamenta o ponto de vista cultural presente nas narrativas literárias e que não transparece, legitimando-se como algo fundamentalmente cultural. Entendido como a expressão de toda uma comunidade, quando, na verdade, oculta o que está por trás das expressões tidas como universais. Isto é, oculta o ponto de vista masculino que norteia muitas das narrativas literárias tradicionais e como aponta Mulvey, a respeito desse olhar dirigido a mulher, "o cinema [e podemos entender, aqui, a literatura tradicional] constrói o modo pelo qual ela deve ser olhada”. E, nesse sentido, Dostoiévski rompe, pondo em cena uma mulher que narra suas vivências a partir do seu próprio ponto de vista, o que explica o estranhamento que a obra causa (e, aparentemente, causou), sobretudo, por aquilo que na obra não se espera de uma atitude de mulher.

Em Niétotchka Niezvânova vislumbramos o modo pelo qual a narradora quer ser olhada. $\mathrm{Ou}$ seja, não há o olhar de outro na figura de um narrador que a submete a sua lei. Ao contrário, Niétotchka é quem submete o leitor a sua lei. Portanto, há uma subversão aqui no ponto de vista masculino arbitrário presente em boa parte das narrativas literárias tradicionais.

Mauro, em seu trabalho sobre a personagem feminina nas narrativas do escritor Alberto Moravia, mostra como ainda é presente o olhar tradicional (ponto de vista masculino) em relação às mulheres nas narrativas literárias. Segundo a autora, "a mulher moraviana surge, então, descrita com riqueza de detalhes em seus aspectos físicos, enquanto que, de seu lado interior, o autor não fala quase nunca." ${ }^{23}$ Mauro, ao analisar os tipos de narradores presentes na obra de Moravia, faz

22 Laura Mulvey. "Prazer Visual e Cinema Narrativo". In: A Experiência do Cinema, organizado por Ismail Xavier. Edições Graal. RJ, 1983. P. 452.

23 Cláudia F. C. Mauro. A Personagem Feminina na Narrativa de Alberto Moravia. Tese de Doutorado, 2001. P. 28. 
uma crítica em relação à falta de coerência e de credibilidade ao apresentar algumas personagens femininas na posição de narrador. ${ }^{24}$

Faccin, no seu trabalho a respeito da coexistência do papel masculino com o do feminino na obra $O$ Grande Gatsby de F. Scott Fitzgerald, corrobora, de alguma forma, o exposto por Mauro e, principalmente, por Mulvey, ao pensar em como a mulher deve ser olhada nas narrativas tradicionais. Faccin cita uma crítica, Parkinson, que argumenta que "Fitzgerald permite que Daisy [personagem feminina de $O$ Grande Gatsby] exista somente nas imagens que os homens criam dela." 25 Vemos na obra literária apresentada por Faccin o modo pelo qual a mulher deve ser olhada. Parkinson, citada por Faccin, afirma ainda que "na ficção desse autor [Fitzgerald] as personagens femininas são figuras decorativas de aparente beleza frágil, apesar de serem frequentemente, na realidade, fúteis, egoístas, destrutivas e impiedosas."26

Dado o exposto, é interessante um ponto colocado por Parkinson para nos fazer pensar em quanto a realidade das personagens femininas é frequentemente omitida, ou, intencionalmente não focalizada, deixando apenas aquilo que deve ser observado. Não raras vezes, é o ponto de vista de outro sobre o que aparentemente é a mulher. A aparência surge, então, como a essência da mulher.

Voltando um pouco às apreciações de Mauro em relação às personagens femininas na obra de Moravia, podemos pensar em como é significativo a personagem feminina ser apresentada por meio de seus traços físicos, na maioria das narrativas de Moravia. E, sendo assim, é a aparência da mulher (aparência física) que ganha espaço em termos de sua representação, e não a realidade da mulher enquanto tal.

Kruger também atenta para a questão da omissão da realidade da mulher nas narrativas, ou, melhor, da realidade da mulher, intencionalmente, não focalizada no seu excelente trabalho sobre o filme Anticristo de Lars von Trier. Para além da abordagem, por assim dizer, destoante da maioria da crítica dessa obra cinematográfica, Kruger analisa a obra cinematográfica usando parâmetros e termos próprios de análises literárias. Enxergando, deste modo, as cenas do filme como narrativas. Tal feitura de análise possibilita um diálogo com a problemática apresentada aqui. Não apenas no tocante ao modo pelo qual a personagem feminina é mostrada no filme, mas, sobretudo, à qual ponto de vista está por trás da figura do narrador.

Segundo Kruger, “especialmente determinante para nossa análise é considerar que, por se tratar de uma narrativa, há no cinema necessariamente uma (ou mais) narração, e que a identificação desta(s) não pode ater-se somente a processos como voz over ou a presença explícita de um narrador." ${ }^{27}$ Como no filme não está explícita a presença de um narrador, ela, por meio de sua

24 Idem. Podemos verificar essa crítica nas páginas 114,115 e 116.

25 Eni Izoleta Faccin. O Resgate da Coexistência Harmoniosa do Papel Masculino com o Feminino em "O Grande Gatsby" de F. Scott Fitzgerald. Disssertação de Mestrado. 2001. P. 36.

26 Idem. P. 28.

27 Patrícia de Almeida Kruger. Penetrando o Éden: Anticristo, de Lars von Trier, à luz de Brecht, Strindberg e outros 
análise detalhada, enxerga na figura do ator Dafoe (o protagonista) o narrador. Nas premissas da autora, "a subjetividade, o estado de espírito de Dafoe também dariam conta de toda a narração de Anticristo, o que nos impele a enxergá-lo antes como foco narrativo do filme do que como uma personagem apresentada pela técnica subjetiva indireta livre. ${ }^{28}$

Além disso, Kruger aponta para a falta de foco na personagem feminina, construída pelo ponto de vista masculino da personagem de Dafoe. Ela tece as seguintes observações: "uma investigação minuciosa de cada um dos planos do filme permitiu-nos concluir que a utilização da câmera subjetiva empregada na obra assume, via de regra, o ponto de vista dessa personagem, apresentando os eventos da narrativa a partir de sua posição e 'com os seus olhos'." ${ }^{29}$ Observando algumas cenas, Kruger afirma o seguinte:

é notável que, desde a primeira sequência do filme, há uma discrepância grande na forma como se comportam as duas personagens em relação a esse processo [direção dos olhares], sendo que o direcionamento do olhar de Dafoe contribuirá para a construção de sua personagem como referencial da narrativa. Gainsbourg [atriz que interpreta a personagem feminina] é plasmada como o objeto do olhar, da investigação dele, como diversos planos do filme mostram, seja pelo uso da câmera subjetiva/Dafoe, seja em planos de conjunto, quando observamos seu olhar claramente direcionado a ela. [...] Já a direção do olhar de Gainsbourg não é tão clara, e em grande parte das cenas seu olhar direciona-se para baixo, ou a vemos com os olhos fechados. ${ }^{30}$

Kruger também aponta para como são construídas, isto é, reproduzidas no filme (narração) as imagens falsas do que é a mulher, tidas como a natureza da mulher. Ela argumenta que

esses são os parâmetros que delimitam como o discurso hegemônico corporificado por Dafoe nos apresenta visões sobre a mulher, como ele retrata imaginários femininos: a mulher como frágil, emotiva, sensível e incapaz de tomar decisões por si própria; a mulher infantilizada e extremamente carente de atenção e da presença de figuras masculinas; a mulher supersticiosa, mística e inapta a articular argumentos com base na realidade e na razão; a mulher instável, incoerente, exagerada e imprevisível, portanto, perigosa; a mulher que é definida pela maternidade; a mulher que deve ser responsável pelo cuidado do filho e pelas tarefas domésticas, sacrificar-se pela família e restringir-se ao âmbito do privado. [...] a mulher ciente de sua desqualificação intelectual e emocional frente aos homens; a mulher misteriosa, indecifrável, cujas motivações são obscuras; a mulher ardilosa e fatal, cuja própria 'natureza' é maléfica. De maneira geral, as relações entre o feminino, a natureza, a irracionalidade e o inconsciente seriam o terreno que Anticristo nos oferece a ser explorado, o que, contudo deve ser feito tendo em mente todos os indícios de que

elementos inquietantes. Tese, 2016. P. 66.

28 Idem, p. 80.

29 Idem, p. 68.

30 Idem, p. 72. 
Dafoe projeta na figura feminina questões relativas a seus próprios processos conscientes e inconscientes o que ratifica, inclusive, que a 'racionalidade masculina' contraposta a esses imaginários revele-se também bastante mistificante. ${ }^{31}$

Ainda sobre o que fundamenta o ponto de vista cultural, tão presente nas narrativas literárias e que reforça, em grande medida, a distorção do que é o feminino, Kruger salienta que

\begin{abstract}
o horror está [em Anticristo], na verdade, nas implicações que o filme traz sobre a vigência do patriarcado na sociedade ocidental contemporânea, sobre os meios culturais e institucionais que o atestam e naturalizam, e sobre sua influência, muitas vezes bastante sutil, na psique dos indivíduos. Sutil o bastante para fazer com que não se perceba sua materialização no foco narrativo pelo filme. Sutil o bastante para que não notemos como estamos imbricados nesse estado de exceção e como esse foco narrativo é legitimado por muitos de nós. ${ }^{32}$
\end{abstract}

Além do exposto, Kruger chama a atenção para o fato de que "em suma, o universo feminino apresentado pelo filme é, sem dúvida, o universo da loucura e da contraposição à razão." ${ }^{33}$ Aqui, cabe uma consideração a respeito da elaboração de Niétotchka. A partir das afirmações de Kruger, podemos pensar que a construção do que é o universo feminino sempre está desassociado da razão. E nesse sentido, pensando em Niétotchka Niezvânova, é válido olharmos com mais cautela para a construção da própria narrativa, cuja narração dos fatos da vida da personagem feminina sugere uma lógica. Isto é, há uma reflexão de como os fatos devem ser colocados. A estruturação da narrativa é muito bem pensada, racionalizada pela própria narradora. Mais adiante falaremos mais dessa questão.

Por ora, pensemos que é simbólico o fato de Niétotchka estar encerrada na biblioteca, cujo espaço físico, até então, era reservado aos homens cultos de sua época. Esse privilégio dos homens surge de tal maneira na narrativa que, logo, vemos se tratar do mesmo espaço onde habitualmente se encontra o marido (personagem masculina) de Aleksandra. E, finalmente, as avaliações de Kruger corroboram a ideia que vimos desenvolvendo até aqui, no sentido de que enxerga também como esse olhar masculino vem imiscuído com a noção do que temos como algo cultural.

Já Ruth Brandão, em seu trabalho sobre a personagem feminina na literatura, toma de empréstimo uma afirmação feita por Shoshana Felman, que acredita na ideia de que "à personagem feminina cabem duas soluções: ou refletir a imagem masculina, metonímia e metáfora de uma

31 Idem, p. 188.

32 Idem, p p. 261-262.

33 Idem, p. 196. 
ideologia opressora ou perder-se no vazio da loucura e da marginalização." ${ }^{34}$ Quem corrobora a afirmação feita por Brandão é Fonseca, em sua tese sobre as personagens femininas no século XIX, na qual destaca o fato de que "essa mistura de elementos pejorativos confluía, geralmente, num quadro maniqueísta da perfeição ou de decadência, mas quase nunca com "realismo". A mulher, que deveria viver para o homem, tinha sua imagem construída também por este." ${ }^{35}$

Valéria Lamego, pensando na representação da mulher na pintura e na literatura do século XIX, argumenta que "no Brasil, a influência do positivismo define praticamente o papel de cada um. À mulher é designado o triplo destino de mãe, esposa e filha." ${ }^{36}$ É sabido que as ideias positivistas ganharam espaço na sociedade russa do século XIX. Além disso, sabemos o quanto Dostoiévski se mostrou contrário às ideias que proliferavam na Rússia. Pensando nas colocações de Lamego e voltando, de certa forma, às considerações de Fonseca, verificaremos que, ao representar a personagem feminina (Niétotchka), Dostoiévski procurou dotá-la de mais "realismo". Isto é, tornála mais humana, indo, deste modo, contra à ideia positivista do papel determinado da mulher na sociedade.

Pensando ainda no triplo destino da mulher a que se refere Lamego, vemos Niétotchka que se desajusta no seu papel de filha. Em outras palavras, a narradora mal se relaciona com a sua mãe, e com o padrasto parece haver na relação entre eles algo que foge da normalidade (que em um segundo momento do trabalho serão melhor analisadas as relações de Niétotchka no seu núcleo familiar). Portanto, não é exatamente um "papel de filha” o que verificamos na narrativa, mas relações ambíguas que se apresentam. E, ao que tudo indica, esse triplo destino da mulher parece não ter encontrado lugar no romance.

O trabalho de Marina Machado de Carvalho se torna de fundamental importância, cujo objetivo é mostrar como as visões sobre o papel da mulher no Positivismo, tidas como progressistas no século XIX, só reafirmavam um lugar de submissão da mulher na sociedade. Aqui, cabe ressaltar que a presente pesquisa visa a discutir de maneira mais ampla tais formulações positivistas, que certamente influenciaram muitos autores no Ocidente e também na Rússia no período do século XIX. É certo que alguns autores russos como Tchernichévski, por exemplo, sofreram influência do Positivismo, mas no sentido de fazer uma crítica contra aquela sociedade russa patriarcal de então. De questionar certos costumes antigos, colocando a Razão no centro de suas discussões. Mas não podemos tomar alguns desses autores russos como a regra. Tolstói, por exemplo, não queria

34 Ruth Silviano Brandão. Mulher ao Pé da Letra: A Personagem Feminina na Literatura. Ed. UFMG. B H, Minas Gerais, 2006. P. 125.

35 Odomiro Fonseca. Niilismo: Estrada para a emancipação. O Destino Literário das Personagens Femininas Russas na Época das Grandes Reformas (1855-1866), 2017. Tese de Doutorado. P. 38.

36 Valéria Lamego. "Retrato de Senhora: A imagem da mulher brasileira na Pintura e Literatura do Século XIX". In: IV Seminário Nacional: Mulher e Literatura. Abralic. Rio de Janeiro, 1992. P. 58. 
repensar o papel subserviente da mulher na sociedade.

Voltando a Carvalho, a autora mostra, a partir de sua análise, algumas raízes de formulações positivistas acerca da mulher, baseadas, essencialmente, nas ciências. Sobre a teoria cerebral de Gall, a autora aponta que

é essa teoria que deve fornecer as informações científicas para que se expliquem as peculiaridades sociais de cada sexo. Essas diferenças, por sua vez, constatadas através do exame anatômico e da observação fisiológica, assinalam a preponderância maior da força intelectual das faculdades especulativas e dos instintos pessoais nos homens adultos; em segundo lugar, elas revelam que nas mulheres e crianças há o predomínio das faculdades afetivas e dos instintos simpáticos ou sociais ao lado de um menor vigor intelectual. ${ }^{37}$

Carvalho cita Comte, quem afirma o seguinte (baseando-se nas teorias biológicas): "como o sexo feminino é superior ao masculino no que tange à simpatia e à sociabilidade, o seu ofício nessas ordens deverá ser limitado apenas à educação das crianças e ao aperfeiçoamento social da razão masculina." 38

Sobre a educação das mulheres na concepção comteana, Carvalho ressalta que "quanto ao aprimoramento do impulso cívico; a não inclusão das mulheres justifica-se, ainda, pela exigência de uma maturidade intelectual impossível a sua natureza afetiva e infantil." ${ }^{39}$ Segundo a autora, "Auguste Comte reserva à mulher, portanto a educação que ao seu ver, melhor caracteriza a sua condição natural e o seu lugar na ordem social: a submissão objetiva e subjetiva, a tutela e a minoridade eternas." ${ }^{40}$ Outra questão importante que ela traz acerca da filosofia comteana é a seguinte:

no pensamento de Auguste Comte, a superação das desigualdades sociais entre homens e mulheres são impossíveis de serem atingidas, tal transformação seria prejudicial às mulheres e a ordem social, uma vez que não são nem o meio, nem a educação que fazem as mulheres tais como elas são e, sim, é a originalidade de seu tipo físico e emocional. ${ }^{41}$

Dadas algumas formulações de Comte, esboçadas por Carvalho, verificamos que Dostoiévski rompe com o paradigma da mulher construído pelo Positivismo quando elabora Niétotchka. Sobre a

37 Marina Machado de Carvalho. A Imagem e a Educação da Mulher no Positivismo. São Paulo, 1991. Dissertação. P.65.

38 Idem, p. 68.

39 Idem, p. 105

40 Idem, p. 112.

41 Idem, p. 117. 
“originalidade de seu tipo físico e emocional” nas mulheres, a que se refere Comte, é notável como o tipo emocional de Niétotchka (que segue na contramão de tais formulações) origina-se de outros sentimentos que emergem na narrativa. Como exemplos, temos a total falta de sociabilidade de Niétotchka (que é evidente na narrativa) e o seu mal-estar perante a sua própria mãe. Fatos esses que, consequentemente, desmontam a tese positivista.

Pensando ainda sobre os "instintos simpáticos ou sociais ao lado de um menor vigor intelectual" presentes nas mulheres, segundo as teorias cientificistas do XIX, é importante salientarmos um aspecto fundamental na personalidade de Niétotchka: a exacerbação do pensamento. O que, aliás, inverte o paradigma positivista. Há, portanto, um vigor intelectual na narrativa, que, inclusive, causa estranhamento e desconforto. Mais adiante, será problematizada a questão da exacerbação do pensamento em Niétotchka Niezvânova. Quanto à "preponderância maior da força intelectual, das faculdades especulativas e dos instintos pessoais nos homens adultos", segundo as teorias do século XIX, é oportuno lembrar que, durante toda a narrativa, as faculdades especulativas de Niétotchka seguem em um crescente. Vejamos:

\begin{abstract}
Mesmo então, na época sombria de minha estranha infância, no período do desenvolvimento tão antinatural do começo da minha vida, meu coração apertava-se frequentemente de dor e compaixão, e a minha alma era penetrada por sobressaltos, pela confusão e pela dúvida. (Dostoiévski: 2009, p. 43)
\end{abstract}

Ainda sobre as ideias positivistas vigentes no século XIX, Carvalho ressalta que

\begin{abstract}
Estado e comunidade; tacitamente, consentem na criação de sistemas de ensino distintos para moças e rapazes e, reservando aos homens a profissionalização, a livre reflexão e a filosofia, contribuem para que a ordem social do século XIX mantenha-se sobre uma estrita repartição dos papéis e dos lugares masculinos e femininos. Quanto às mulheres, afastadas desse ensino reflexivo e profissional, ficam destinadas à dependência masculina, seja para a manutenção econômica de sua sobrevivência, seja para compor os quadros sociais mais importantes. ${ }^{42}$
\end{abstract}

Vemos, então, mais uma quebra com esse paradigma. Niétotchka, na casa de Aleksandra Mikhailóvna, vai-se "profissionalizando" (por assim dizer) quando começa a ter aulas de canto. Ao que tudo indica, a nossa narradora parece ter um talento que logo seria reconhecido. Joseph Frank, ao analisar Niétotchka Niezvânova, chama a atenção para esse aspecto, afirmando que "acredita-se 
geralmente que Niétotchka se tornaria uma grande cantora lírica." ${ }^{43}$

Sobre as ambiguidades de Niétotchka, que serão mais bem destacadas no próximo capítulo, são oportunas as considerações de Rita Terezinha Schmidt a respeito da representação da duplicidade feminina:

ao possibilitar a emergência da mulher como significante de si mesma, ao tornar visível o ser que o poder reprime, a duplicidade desponta como força disruptiva pois estabelece uma relação descontínua, de não-identidade com a imagem projetada como verossímil ideológico que enfatiza continuidade e unidimensionalidade. ${ }^{44}$

Podemos pensar que a ambiguidade presente na Niétotchka lança luz sobre a questão de "nãoidentidade com a imagem projetada como verossímil ideológico" a que a autora se refere. Niétotchka escapa do modelo de representação do que é o feminino. A começar por um ponto importantíssimo na narrativa: a sua vida e as suas expectativas não estão atreladas a um homem, como acontece com a maioria das personagens femininas.

E isso pode ser verificado nas personagens elencadas acima. A começar por Várvara de Gente Pobre que, no fim do romance parte para bem longe com o seu recente marido, cujo desfecho será servi-lo e dar continuidade a existência passiva e obediente ao homem. Katierina de $A$ Senhoria, por sua vez, vive em função da atração que o personagem Múrin lhe desperta, não rompendo dessa forma com a ideia da mulher viver em função do homem. E, finalmente, Nastienka de Noites Brancas vê seu futuro ao lado de um homem por quem espera há um ano. É a mesma lógica de ver a mulher submetida ao homem. Niétotchka, apesar de, num primeiro momento, ver-se ligada de maneira exacerbada por seu padrasto, isto é, por um homem (que, na verdade, aparece na narrativa ligado à primeira experiência) rompe com a ideia da vida da mulher ter que, necessariamente, estar voltada ao homem.

Há outra inversão apresentada em Niétotchka Niezvânova: observamos uma relação mais afetuosa e íntima da narradora com outra menina. Ou seja, não é a figura do homem amado, mas da mulher amada. A própria narrativa se encaminha de tal forma que nós leitores não conseguimos associar Niétotchka ao desfecho típico da maioria das personagens femininas. Além disso, não vemos a heroína buscar o amor na figura de um homem, e menos ainda como sendo o motivador da sua existência. É clara a distinção da narradora.

Lima, em seu trabalho sobre as personagens femininas nos contos de Tchékhov, chama a

43 Joseph Frank. Dostoiévski: As Sementes da Revolta, 1821-1849. São Paulo. Edusp, 2008. P. 440.

44 Rita Terezinha Schmidt. “Um Jogo de Máscaras: Nélida Piñon e Mary McCarthy”. In: A mulher na Literatura, v.1. Imprensa da Universidade Federal de Minas Gerais, 1990. P. 216. 
atenção para o aspecto dessa não-unidimensionalidade do caráter da mulher, retratada na literatura, visto aqui também na elaboração tchekhoviana no século XIX. Segundo o autor,

outra característica muito importante dos primeiros contos do escritor é a criação de uma imagem fragmentada da mulher: com isso, ele pretende retratar a mulher não apenas como uma acompanhante dos homens, e sim, como um indivíduo de psicologia diversa da masculina e que também quer percorrer o seu caminho. ${ }^{45}$

Kruger, pensando nesse objeto de investigação que é a mulher (também na literatura), afirma que

enquanto objeto da investigação de Dafoe [narrador de Anticristo] e preenchendo, em um nível alegórico, o papel do feminino, do Outro, Gainsburg [personagem feminina de Anticristo] parece ser definida, perscrutada e interpretada em relação ao padrão, à norma, que, não esqueçamos, é masculina por excelência em nossa cultura. ${ }^{46}$

Podemos pensar, com o exposto por Kruger, em como muitos dos narradores em primeira ou terceira pessoa cumprem com a tarefa de apenas representar o padrão do que é entendido como o feminino. E, sendo assim, é só uma forma masculina de enxergar o feminino. Corrobora essa observação de Kruger a afirmação de Schmidt de unidimensionalidade da mulher.

Um ponto importante a ser discutido é a questão da espacialidade em que surgem as personagens femininas. Bella Josef atenta para essa particularidade envolvendo as personagens femininas, afirmando que

há uma espécie de relações que funcionam como eixo de estruturação desses romances, a relação da mulher com a natureza, com a ordem social e a relação da mulher com o homem. Em primeiro lugar se observa que a existência das heroínas transcorre no espaço fechado da casa, lugar aconchegante, seguro. ${ }^{47}$

Dadas as considerações de Josef, verificaremos que as personagens tratadas aqui são apresentadas no espaço da casa, com algumas especificidades. Todavia, a ideia do lugar da casa, o

45 Rodrigo Ferreira Lima. Um estudo da personagem feminina nos contos de Tchékhov. São Paulo, 2012. Dissertação. Pp. 49-50.

46 Patrícia de Almeida Kruger. Penetrando o Éden: Anticristo, de Lars von Trier, à luz de Brecht, Strindberg e outros elementos inquietantes. Tese, 2016. P. 162.

47 Bella Josef. "A Mulher e o processo criador (a máscara e o enigma)”. In: Feminino Singular: a participação da mulher na literatura brasileira contemporânea. Edições GRD. São Paulo, Rio Claro, 1989. P. 51. 
espaço físico onde circulam as personagens é muito forte. Embora a personagem Nastienka se encontre no espaço da rua, sob as noites brancas de São Petersburgo, ou seja, fora da casa, não devemos perder de vista que tal fato se dá, de se encontrar fora do espaço da casa, porque ela escapa à noite dos cuidados da avó. A vida de Nastienka não se dá fora do espaço da casa, na medida em que a personagem, quando fora do espaço doméstico, só o faz com o intuito de reencontrar o homem amado. A fim de prosseguir a sua vida no lar ao lado dele. Portanto, não há uma quebra significativa.

As personagens Katierina e Várvara seguem o mesmo destino. A primeira personagem, literalmente, vive no espaço doméstico, alternado com o espaço da igreja. Aliás, espaços típicos e destinados às mulheres. No que tange à Várvara, a casa não apenas será o espaço no qual se dará a correspondência (por cartas) dela com o personagem Diévuchkin, como também será o lugar de trabalho que garantirá o seu sustento. Várvara ao se casar, com objetivo de ter filhos, de cuidar da casa e do marido, reforça, assim, esse lugar-comum.

Niétotchka, apesar de se encontrar no espaço da casa, tem outra relação com o espaço. O espaço da casa para a narradora se configura de outra forma. Sobre o espaço da casa, "aconchegante" e "seguro", a que se refere Bella Josef, é oportuno lembrar que, a insegurança e a hostilidade se fizeram presentes nas casas onde se encontrou a narradora. Como a água-furtada, local onde ela passou parte da sua infância com os pais, bem como a casa de Aleksandra Mikháilovna. Ao contrário da ideia de lugar fechado e seguro, Niétotchka não encontrou aconchego e menos ainda segurança nesses espaços. Basta-nos lembrarmos dos momentos da narrativa na casa de Aleksandra para enxergarmos toda a instabilidade do futuro da narradora.

O recolhimento de Niétotchka mais tem a ver com uma postura da época (ou melhor, simboliza uma postura de alguns intelectuais daquele período) do que com o recolhimento da mulher. $\mathrm{Na}$ narrativa, ela é identificada com algumas pessoas do seu tempo. Portanto, o recolhimento de Niétotchka pode ser entendido não no espaço da casa, do lar, mas, fundamentalmente, no espaço do subsolo.

Américo, em seu artigo sobre a construção da imagem feminina de Moscou na literatura russa, traz uma questão importante para pensarmos a elaboração de Niétotchka e, principalmente, a distância que a narradora toma em relação às personagens descritas acima, mesmo no conjunto geral de elaboração da personagem feminina da época. Segundo o autor,

além da metáfora de uma mulher jovem, muitos dos escritores russos do século XIX descrevem Moscou como uma velha ou viúva. Em comparação com a nova capital em desenvolvimento, Moscou 'começou a ser percebida como mais arcaica do que era' (Iussúpov, 2000, p. 10). Já São Petersburgo, desde o momento de sua criação, foi relacionada ao nome de Pedro, o Grande, e, por 
Dadas as considerações do autor, podemos pensar que Niétotchka se enquadra mais na ideia do que simboliza São Petersburgo. Isto é, a narradora de Petersburgo é símbolo do novo olhar sobre a imagem da mulher, em contraposição à imagem feminina de Moscou arcaica. A qual é estereotipada e ligada a valores antigos, ou seja, ligada ao velho papel feminino definido da mulher. Para elucidar melhor a questão, pensemos na característica fundamental de Niétotchka que a liga às personagens de São Petersburgo (como, por exemplo, ao homem do subsolo e ao próprio Raskólnikov, quem, para muitos, é por excelência uma criatura do subsolo): a exacerbação do pensamento. Nas palavras da nossa narradora:

Às vezes - e isso acontecia com frequência crescente - experimentava uma estranha necessidade de ficar sozinha e pensar, pensar sempre: eram momentos parecidos com os do tempo em que ainda morava em casa dos meus pais e em que, antes de me afeiçoar a meu pai, passara um ano inteiro pensando, considerando tudo, prestando atenção, do meu canto, ao mundo de Deus, de jeito que, por fim, tornara-me completamente selvagem, em meio aos espectros fantásticos, por mim mesma criados. (Dostoiévski:2009) p. 157

Como observado, Dostoiévski rompe com a ideia geral de que apenas os homens são dotados da "capacidade de pensar". Niétotchka se configura na narrativa como um ser pensante, ou melhor, como a mulher enquanto ser pensante. Dostoiévski procura igualá-la ao aproximá-la das características consideradas como do universo masculino. Podemos entender isso, como uma busca de igualdade.

Bianchi aponta para a questão e salienta que,

\begin{abstract}
Dostoiévski mesmo chegou a participar de discussões acirradas com o crítico russo conservador M. Kátkov, no início dos anos de 1860, expondo sua posição em favor da emancipação feminina, que na sua concepção consistia 'num amor cristão à humanidade... que as mulheres também tinham o direito de exigir para si'. [...] 'Quanto mais corretamente se desenvolver a sociedade, mais ela será normal, mais próxima estará do ideal da humanidade, e nossa relação com as mulheres se definirá por si mesma, sem quaisquer projetos e utopias preestabelecidas', escreve ele. ${ }^{49}$
\end{abstract}

Leonid Grossman traz um fato interessante na segunda parte de seu trabalho, sobre a biografia de Dostoiévski. Grossman salienta o fato de como o autor russo conseguiu intervir no resultado do julgamento de uma mulher, acusada de ter tentado contra a vida de uma criança. Ele interveio, na

48 Edelcio Américo. A Imagem Feminina de Moscou na Literatura Russa. Revista Rus. São Paulo. Pp. 23-24.

49 Fátima Bianchi. O Tema da Submissão Feminina na Novela Uma Criatura Dócil. In: Caderno de Literatura e Cultura Russa, n. 2. Ateliê Editorial. São Paulo, 2008. P. 327. 
verdade, depois de procurá-la e saber por ela como, realmente, as coisas se sucederam.

15 de outubro. Veredito do tribunal sobre o caso da camponesa Kornílova; que atirou de um quarto andar a sua enteada de seis anos (a menina ficou viva). A acusada foi condenada a dois anos e oito meses de trabalhos forçados e, após este prazo, à residência perpétua na Sibéria.

Fim de outubro ou começo de novembro. Dostoiévski visita Kornílova, num compartimento especial da casa de detenção.

Dezembro. Recebe a comunicação de ter sido anulado o veredito do julgamento de Kornílova, em virtude da transgressão do Artigo 693 do Código de Processo Penal, devendo o processo ser examinado novamente por outra seção do tribunal, com a participação de jurados.

22 de abril. Dostoiévski presencia o segundo julgamento do caso de Konílova, no tribunal distrital. Absolvição da acusada. O presidente do tribunal e o promotor declararam durante o julgamento que o primeiro veredito fora anulado em consequência da suposição expressa no Diário de um escritor, no sentido de que o estado de gravidez poderia ter influído na ação da acusada (Diário de um escritor, 1877, abril, II). Em seu resumo, o presidente advertia os jurados no sentido de que "não se sujeitassem à influência de alguns literatos talentosos".

24 de abril. Depois do veredito absolutório, o casal Kornilov faz uma visita a Dostoiévski. 50

Verifica-se pelo exposto acima (sobre a própria postura do autor russo) a busca em entender o outro, que no caso é a mulher. É interessante notar, pensando nas ambiguidades de Niétotchka (que temos como bom exemplo disso o seu mal-estar diante da mãe), a não romantização da imagem da mulher, mas a sua humanização, que pressupõe, sim, posturas ambíguas. Kornílova (citada acima) tinha arremessado uma menina do quarto andar. É óbvio que não foi um gesto digno, porém, a questão é que todo ser humano possui as suas contradições. Ele não nega esse estado de coisas na mulher.

Se atentarmos para a elaboração das personagens femininas dostoievskianas, notaremos que as mulheres na obra de Dostoiévski são peças fundamentais no sentido de, artisticamente, representarem as ideias do autor. Além disso, as mulheres elaboradas por Dostoiévski são sempre humanizadas, seja no sentido de expressarem a bondade humana ou a malignidade humana. Muitas vezes, ambas as características convivendo em um único ser, como é o caso da nossa narradora.

A elaboração de Sônia Marmeládova, por exemplo, funciona como símbolo do ápice da humanidade. No sentido da compaixão humana, que transcende na figura dela. Sônia Marmeládova está à altura do príncipe Míchkin no tocante à elevação espiritual. Dostoiévski considerava a 
personagem de O Idiota o homem positivamente belo. E, sendo assim, podemos dizer que Soniétchka é sem dúvida a mulher positivamente bela nas obras de Dostoiévski. Em contrapartida das personagens espiritualmente belas e elevadas, encontram-se as personagens cindidas, em que o advento da dúvida paira sobre os seus corações. Pensemos, por exemplo, no homem do subsolo que encontra o seu par feminino na Niétotchka. Portanto, as peculiaridades da nossa narradora são apresentadas enquanto de um ser humano e não enquanto de um papel social da mulher. Ideia esta, propagada pelo Positivismo no século XIX, com o qual Dostoiévski rompe definitivamente, fazendo emergir a humanidade da mulher em seus diversos aspectos que, exaustivamente, ele procurou representar em suas obras.

Dado o exposto acima, é válido lembrar que o jovem escritor Dostoiévski de 1840 se difere bastante daquele que ele virá a se tornar posteriormente. Em sua biografia, a respeito do seu casamento com Dostoiévski, Ana Grigorievna Dostoievskaia afirma que "um dos motivos de discórdia era a chamada "questão feminina" "51. Prosseguindo seu relato diz: "devo afirmar que Fiodor Mikhailovitch realmente não gostava das niilistas daqueles tempos [década de 60 do século XIX]. ${ }^{~} 52$ É sabido que Dostoiévski teve um rápido caso amoroso e conflituoso com Apolinária Suslova (entre 1862 e 1863) que era niilista. Frank chama a atenção para a personalidade desta, afirmando que "Suslova era uma jovem feminista russa dos anos 1860, que zombava da opinião pública convencional e desdenhava as ideias sustentadas por essa opinião com referência às relações entre os sexos." 53

O ressentimento com as niilistas pode ter relação com esse perturbado caso extraconjugal do autor russo. Reiterando o que foi dito anteriormente: devemos nos ater à personalidade do jovem Dostoiévski, ou seja, ao autor que elaborou e publicou Niétotchka Niezvânova na década de 1840, para compreendermos em que circunstâncias essa obra, que coloca no centro da narrativa uma mulher narrando suas experiências a partir do seu próprio ponto de vista, foi gerada. Para tal empreendimento, faz-se necessário uma digressão à época de 1840, ou melhor, às ideias que circulavam no meio em que Dostoiévski frequentava.

Sabe-se que Dostoiévski foi preso por participar do Círculo de Petrachévski, que agrupava um número considerável de intelectuais, às sextas-feiras, com a finalidade de discutir questões sociais e políticas. Petrachévski que reunia esses intelectuais em sua casa sempre demonstrou uma postura de ruptura, isto é, de não-subserviência ao conjunto de regras morais e sociais daquela época. Frank coloca que "dizia-se que, certa vez, tinha ido [Petrachévski] à igreja vestido de mulher; em outra ocasião, após receber ordens de cortar o cabelo, apareceu na repartição com voluptuosos cachos..." ${ }^{44}$

51 Ana Grigorievna Dostoievskaia. Meu Marido Dostoiévski. Rio de Janeiro. Mauad, 1999. P. 124.

52 Idem, p. 125.

53 Joseph Frank. Dostoiévski: Os Efeitos da Libertação, 1860-1865. São Paulo. Edusp, 2013. P. 354.

54 Joseph Frank. As Sementes da Revolta, 1821 a 1849. São Paulo. Edusp, 2008. P. 317. 
Embora J. Frank aponte para como Petrachévski não se alinhava tanto aos que buscavam uma mudança política mais radical, verifica-se, de todo modo, que a ruptura com muitas questões estava colocada nessas reuniões, às quais, frequentemente ou não, Dostoiévski tomava parte.

Frank chama a atenção para uma personagem aristocrática presente nessas reuniões e que exercerá uma grande influência no jovem Dostoiévski. Segundo Frank, “[...] no meio do amorfo aglomerado de pessoas que compunham o círculo de Petrachévski, o obstinado e inflexível Spechniev era um dos que estavam mais tenazmente determinados a transformar as palavras em ações..." ${ }^{55}$

A relação do jovem Dostoiévski era tal com Spechniev que criaram depois uma sociedade secreta. Frank atenta para um dado importante nessas relações do jovem escritor russo, observando que

\footnotetext{
o grupo de Spechniev, como se verá, tentou mobilizar o círculo [de Palm-Dúrov] com a finalidade de reproduzir e distribuir propaganda revolucionária (o plano exposto por Dostoiévski durante sua visita noturna a Máikov), mas jamais conseguiram fazê-lo. Por último, não há dúvida alguma de que Dostoiévski, como membro da sociedade secreta, dedicou-se à atividade conspiratória durante todo esse período. ${ }^{56}$
}

Alguns críticos preferem considerar que Dostoiévski nunca se envolveu de fato com esses círculos, que tendiam para a revolução. Contudo, verificamos o seu envolvimento com esses propagadores da revolução. O exposto acima por um dos maiores biógrafos do escritor russo, como também o pronunciamento de Dostoiévski feito, posteriormente, sobre o período de sua mocidade, dão sustentação para a afirmação feita aqui.

Nas palavras de Dostoiévski (presentes no Diário de um Escritor): "quanto a tornar-me um netchaievista, já não posso garantir, talvez, quem sabe [...] nos meus tempos de mocidade." ${ }^{57}$ Outro fato que atesta a sua colaboração e afinidade com essas ideias revolucionárias foi a carta dirigida ao general E. I. Totleben, quando se encontrava como soldado raso e intencionava elevar o seu posto. Dostoiévski diz: "eu era culpado [...] Reconheço-o integralmente. Fui condenado por ter a intenção (mas só a intenção) de agir contra o governo." 58

Isso exposto, podemos tecer algumas conjecturas a respeito das circunstâncias em que Niétotchka Niezvânova fora produzida. Dados esses fatos na vida do autor russo, nos anos de 1840, não é de admirar que, por exemplo, em Niétotchka Niezvânova a questão da homoafetividade surja 
de maneira naturalizada. Isto é, não há somente a inserção do assunto (que discorreremos mais adiante), mas, sobretudo, a sua naturalização. Isso mostra uma ruptura com o velho modo de se olhar para a questão evidentemente. Como pudemos observar, Dostoiévski estava envolvido com homens intelectuais dispostos a perturbar e a mudar a ordem de então. E o dado da homoafetividade que surge na obra de 1840 é simbólico, na medida em que mostra como esses jovens intelectuais tinham sede por mudanças. É sabido também que a questão da emancipação das mulheres, já nesse período de 1840, também figurava como um assunto a ser discutido.

Não podemos perder de vista a grande estreia de Dostoiévski, quem põe no centro de sua primeira e tão aclamada obra um personagem masculino, cuja raiz do sobrenome (Diévuchkin) vem da palavra em russo diévuchka, que em português significa moça. Ou seja, a escolha do nome (sobrenome) do seu primeiro personagem masculino foi intencional, tem uma carga simbólica, que inevitavelmente acaba dialogando com a sua maneira de pensar. Dostoiévski dota-o de qualidades tidas como femininas intencionalmente. E se nos atermos à postura de muitos desses intelectuais que o rodeavam, não é difícil percebermos a relação dessas ideias com o modo que surgem certos temas na obra analisada aqui.

A sensibilidade de Dostoiévski é verificada na elaboração de suas personagens literárias. Dostoiévski sempre procurou representar as mulheres de maneira mais humana, diferentemente de outros escritores da época que tendiam para uma representação da mulher no sentido de até demonizá-las ${ }^{59}$. E, sendo assim, chamou a atenção de Freud, quem considerava Dostoiévski um homossexual reprimido, tendo em vista sua sensibilidade para várias questões que, inclusive, Freud identificava em alguns de seus personagens. Nas palavras de Freud,

\begin{abstract}
dos dois fatores que reprimem o ódio pelo pai, o primeiro, ou seja, o medo direto da punição e da castração, pode ser chamado de anormal; sua intensificação patogênica só parece surgir com o acréscimo do segundo fator, o temor à atitude feminina. Dessa maneira, uma forte disposição bissexual inata se torna uma das pré-condições ou reforços da neurose. Uma disposição desse tipo deve ser certamente suposta em Dostoiévski, e ela se mostra sob forma viável (como homossexualismo latente) no importante papel desempenhado pelas amizades masculinas na vida dele, em suas atitudes estranhamente ternas para com rivais no amor e em sua notável compreensão de situações que só são explicáveis pelo homossexualismo reprimido, como muitos exemplos extraídos de seus romances demonstram. ${ }^{60}$
\end{abstract}

É interessante um aspecto que Freud coloca em suas observações: a notável compreensão de situações na obra de Dostoiévski. Ora, mas não era exatamente esta a busca do autor russo,

59 Pensemos, por exemplo, na obra $O$ Diabo de Tolstói.

60 S. Freud. Dostoiévski e o Parricídio. In: Obras Psicológicas Completas, v. XXI. 1974. P. 213. 
compreender as situações humanas? Será que só podemos entender o outro (a mulher, por exemplo), sendo como ele ou é possível, em um tremendo esforço, colocarmo-nos no lugar do outro para assim tentarmos entendê-lo? Para além dessas interpretações de Freud, que procurava a raiz de tal sensibilidade, podemos observar as relações de Dostoiévski com algumas das mulheres de sua vida.

Observando mais atentamente alguns trechos de sua correspondência com as duas esposas que teve em vida, chama-nos a atenção uma recorrência em sua fala ao tratar da personalidade de ambas, ou seja, Dostoiévski se referia sempre ao bom coração que ambas possuíam. Isto, como a sua correspondência mostra, tinha um grande valor para ele.

Sobre a primeira mulher ${ }^{61}$, o autor russo retrata-a como: "atraente, muito culta, muito inteligente, bondosa, gentil, graciosa, de excelente e generoso coração." ${ }^{62} \mathrm{Na}$ biografia de sua segunda esposa, Ana Grigorievna, vemos novamente essa fala do autor russo. A autora das reminiscências observa a seguinte fala de Dostoiévski em decorrência de seu casamento: “- Vejam como ela é encantadora! Ela é uma pessoa maravilhosa! Tem um coração de ouro!”63

E, sem muitos esforços, podemos pensar que esse bom coração da mulher (visto assim por Dostoiévski) estava intimamente ligado ao seu modo de olhá-la. Dostoiévski via na figura da mulher a compaixão humana, tema tão perseguido pelo autor de Os Irmãos Karamazov, cuja personagem feminina mais emblemática, como colocado anteriormente, é Sônia Marmeládova de Crime e Castigo. Façamos uma observação: não podemos entender esse "bom coração" da mulher, a que Dostoiévski se refere, em termos de que se valiam o Positivismo. Parece-nos que esse aspecto enxergado na mulher para Dostoiévski estava ligado a uma ideia maior, de harmonia buscada pelos homens. Em uma carta dirigida a sua primeira esposa, Maria Dmítrievna, quando o autor russo ainda era um soldado raso, Dostoiévski confessa que

em certos momentos, até o melhor dos homens, se assim posso dizer, não passa de um cabeça-dura. O coração de uma mulher, sua compaixão, seu interesse, a bondade infinita que não conseguimos sequer imaginar, e que, muitas vezes, por estupidez, sequer notamos, é insubstituível. ${ }^{64}$

Cabe aqui salientarmos também que Dostoiévski, ao representar a mulher na literatura, procurou representá-la da maneira mais fidedigna possível, não perdendo de vista a consciência que tinha de suas limitações, afinal, era um homem tentando dar voz às personagens femininas. E

61 Nas biografias de Dostoiévski, notamos a ênfase que se dá ao caráter difícil de sua primeira esposa. Todavia, Maria Dmítrievna se embrutecera pelas circunstâncias difíceis de sua vida.

62 Joseph Frank. Dostoiévski: Os Anos de Provação 1850 a 1859. 2008. P. 288.

63 Ana Grigorievna. Meu Marido Dostoiévski. Rio de Janeiro. Mauad, 1999. P. 86.

64 Joseph Frank. Dostoiévski: Os Anos de Provação 1850 a 1859. 2008. P. 285. 
percebemos essa tentativa de dar voz à Niétotchka por meio da intencional ausência de um narrador em terceira pessoa.

É interessante observarmos o fato de que Dostoiévski nunca mais colocou no centro de suas narrativas uma mulher que falasse de suas experiências, a partir de seu próprio ponto de vista. Niétotchka é a primeira e única. Podemos pensar que Dostoiévski, com a experiência que teve com a elaboração de Niétotchka Niezvânova, tivesse notado o esforço que lhe exigia falar sobre o outro (a mulher), sem ser esse outro. Sobre esses temas que, por assim dizer, exigiam-lhe um tremendo esforço, o autor russo algumas vezes chegou a declarar que "sendo mais poeta que artista, sempre assumi temas superiores a minhas forças [...] sem consultar minhas possibilidades, e deixando-me levar pelo impulso poético, eu me abalanço a expressar uma ideia artística superior a minhas forças." 65

Isso também pode estar ligado à questão da verossimilhança, tão cara aos escritores russos e, sobretudo, a Dostoiévski. Podemos pensar que para ele (depois da elaboração de Niétotchka Niezvânova) era mais verossímil colocar a mulher no centro de suas narrativas, quando isto se fazia necessário, por meio de um narrador em terceira pessoa (ou em primeira pessoa) que substituiria assim, em realidade, a sua posição, o seu lugar de fala. Ou seja, o lugar daquele que vê de fora. Seria, então, nessa perspectiva, mais condizente com a "realidade" falar da mulher de fora, como o outro que a vê de longe. E, como aqui em Niétotchka Niezvânova, Dostoiévski se deixou "levar pelo impulso poético", viu-se obrigado a eliminar o narrador em terceira pessoa, tentando, assim, tirar esse ponto de vista masculino da narrativa. Vejamos agora como se configuram as relações dessa personagem feminina com o outro.

65 Leonid Grossman. Dostoiévski Artista. Rio de Janeiro. Civilização Brasileira, 1967. P. 26. 
2. DAS AMBIGUIDADES AFETIVAS (E DISCURSIVAS) EM NIÉTOTCHKA NIEZVÂNOVA 


\title{
2.1 Niétotchka e Iefimov
}

No início da narrativa, é interessante notar que antes de nos pôr em contato com a sua infância, aliás, singular infância, Niétotchka faz questão de, primeiramente, colocar em foco a vida de seu padrasto.

\begin{abstract}
A marca deixada por ele em minhas primeiras impressões de criança foi tão forte que influenciou o resto de minha vida. (Dostoiévski: 2009, p. 9)
\end{abstract}

Como bem coloca a narradora, a história de Iefimov (para a qual Niétotchka reservará um capítulo inteiro) esclarecerá como o caráter da personagem se desenvolve a partir dessa experiência com o padrasto. Quais eram as qualidades dessa figura tão central na vida de Niétotchka? A narradora vai desfilando uma série de circunstâncias nas quais Iefimov se encontra: I) suas relações com algumas personagens, como o músico B., quem, segundo ela mesma, a informou de toda a trajetória de vida de seu padrasto; II) sua relação com a mãe de Niétotchka, que invariavelmente é apresentada de maneira bem superficial. Mas chama a atenção a relação que se estabelece entre Iefimov e certo violinista italiano, bem antes daquele fazer amizade com o violinista B.

\footnotetext{
Meu padrasto entrou para essa orquestra como clarinetista. Tinha vinte e dois anos, quando conheceu um estranho indivíduo. No mesmo distrito residia um conde rico que estava se arruinando com a manutenção de um teatro em casa. Naquela ocasião demitira, por mau comportamento, o regente de sua orquestra, um italiano que realmente não prestava. (Dostoiévski:2009, pp. 9-10)
}

Niétotchka vai narrando todos os infortúnios desse italiano, desde sua demissão, que o arrasta para o alcoolismo, até a sua rápida trajetória de vida que culmina "numa vala junto a uma barragem". É com este homem que o padrasto da narradora mantém relações que "eram inexplicáveis e estranhas". Parece, dada a maneira como essa amizade tão fortuita entre ambos surge nas reminiscências, que tal fato é o ponto de partida para certas mudanças no comportamento de Iefimov.

[...] Isso tudo está acontecendo depois que aquele demônio se ligou a mim...

- Quem? - perguntou o proprietário.

- Aquele que morreu como um cão perdido, o italiano.

- Foi ele quem te ensinou a tocar, Iegóruchka?

- Sim! Ensinou-me muita coisa mais, para minha perdição. Seria melhor que nunca o tivesse conhecido. (Dostoiévski:2009, p. 16) 
Essas passagens parecem surgir de forma muito sugestiva na obra, o que podemos depreender é que o contato de Iefimov com o italiano de algum modo se refere ao contato da personagem com o de fora, ou seja, com o Ocidente. E, ao que tudo indica, pelas qualidades depreciativas que aparecem na narrativa em relação ao italiano, tais como "mau comportamento" e "não prestava", é um contato que traz a dúvida e, sobretudo, é entendido como algo negativo. Curioso notar que, apesar de muito rápido, esse contato fortuito com o italiano deixa marcas profundas no caráter do padrasto de Niétotchka.

[...] Mas - contava B. - eu não podia deixar de me surpreender com o caráter estranho do meu amigo. Desenrolava-se a meus olhos o combate desesperado, febril, entre uma vontade convulsivamente tensa e uma impotência interior. (Dostoiévski:2009, p. 20)

[...] Mas o que me deixava mais espantado - acrescentava B. - era a existência nesse homem, a par de sua completa impotência e de seus insignificantes conhecimentos da técnica, de uma compreensão profunda, tão nítida e, pode-se dizer, instintiva, da arte. Ele compreendia-a e sentia-a dentro de si com tamanha intensidade, que não é de admirar o fato de se ter confundido a respeito de si mesmo, [...] Por vezes, conseguia, em sua linguagem rude e singela, alheia a toda ciência, dizer-me verdades tão profundas, que eu ficava encurralado e não lograva compreender de que modo ele pudera adivinhar tudo aquilo sem ler coisa alguma, sem nunca ter estudado. E eu the devo muito - acrescentava B. - a ele e aos seus conselhos, que muito me ajudaram no meu aperfeiçoamento. (Dostoiévski:2009, p. 21)

As ideias de Kirpótin ajudam a entender essa amizade entre Iefimov e o violinista italiano, a qual se estabelece assim de repente entre eles. Segundo o autor,

\begin{abstract}
a inspiração de Dostoiévski começou a funcionar quando ela se concentrou na fratura, na comoção, na explosão dos acontecimentos que chegam de repente, que vêm não se sabe de onde e prometendo sabe-se lá que resultados. O "de repente" encontrado com frequência na obra de Dostoiévski não é conceito de uso estilístico, mas histórico-filosófico, uma explicação original para as transformações que ocorriam na vida da sociedade e na vida do homem. ${ }^{66}$
\end{abstract}

De fato, pensando nessa ideia de Kirpótin, na década de 40 do século XIX, na qual esta obra está inserida, muitas ideias advindas da Europa e, principalmente, a ideia de racionalização da vida estavam ganhando terreno na Rússia daquela época. Não somente podemos pensar que o italiano tem aí, na narrativa, um sentido simbólico do que significava essas ideias do Ocidente, como também podemos notar, nesse pequeno fragmento acima, que essa influência se dispõe no próprio caráter de Iefimov. Ao retratar a personalidade do amigo, B. pontua muito bem essas contradições 
que constituem o caráter do padrasto da narradora. A arte entra aí de maneira alegórica, para mostrar o embate entre o instinto do homem e o seu desejo de racionalização.

Além disso, algumas características de Iefimov chamam a atenção e, mais tarde, poderão pôr luz sobre certos fatos da vida de Niétotchka.

[...] Pouco depois, B. notou que seu amigo se tornava, cada vez com mais frequência, presa da apatia, da tristeza e do tédio, que os seus arroubos de entusiasmo rareavam mais e mais, sobrevindo-lhe um desalento sombrio, selvagem. [...] Pouco a pouco, Iefimov chegou ao mais extremo cinismo: não se acanhava nem um pouco de viver à custa de $\mathrm{B}$. e até se portava como se tivesse pleno direito a isso. (Dostoiévski:2009, p. 21-22)

Já temos aqui, na figura de Iefimov, que se julga um homem extraordinário, esse complexo de Napoleão, que mais tarde Dostoiévski desenvolverá de maneira extraordinária em Raskólnikov, personagem de Crime e Castigo. Priscila Marques afirma que "Raskólnikov vai transitando de um oposto a outro, passando, por exemplo, do extremo sentimento de humanidade e altruísmo ao mais frio e calculista egocentrismo" ${ }^{67}$. E essa transitividade de sentimentos podemos verificar também em Iefimov

\begin{abstract}
Iefimov ouviu com profunda emoção o antigo companheiro. À medida que B. falava, suas faces pálidas animaram-se e tingiram-se de vivo rubor. A audácia e a esperança puseram em seus olhos um desusado fulgor. Não tardou, porém, que essa nobre temeridade recaísse na presunção, transformando-se logo na sua habitual insolência, e por fim, quando B. estava terminando a sua exortação, Iefimov já o ouvia distraído e impaciente. No entanto, apertou-lhe com ardor a mão e agradeceu-lhe; mas passando de súbito, como de costume, da mais profunda humildade e do maior desalento à mais altiva arrogância, disse com autossuficiência que o amigo não devia afligir-se com a sua sorte; que ele sabia como acomodar o seu futuro; que contava obter dentro em breve uma valiosa proteção, e que iria dar concertos e alcançar de um só golpe a glória e a fortuna. (Dostoiévski:2009, pp.25-26)
\end{abstract}

Schnaiderman, em seu estudo sobre $O$ Senhor Prokhártin, também chama a atenção para esse procedimento em Dostoiévski. Ele argumenta que

como é inerente ao processo dostoievskiano, já notado por muitos estudiosos, particularmente André Gide, ele introduz nas ações de suas personagens a dialética dos sentimentos, isto é, determinado sentimento é substituído bruscamente pelo seu contrário. ${ }^{68}$

67 Priscila Marques. “A Condição Humana em Crime e Castigo”. In: Caderno de Literatura e Cultura Russa, n. 2. Ateliê Editorial. São Paulo, 2008. P. 151.

68 Boris Schnaiderman. Dostoiévski Prosa Poesia, São Paulo. Editora Perspectiva, 1982. P. 80. 
Quem atenta também para essa particularidade, nomeando como a "cinética da forma", presente em Memórias do Subsolo, é Vassoler, em sua tese sobre Dostoiévski. Segundo o autor, “o protagonista se avilta e se eleva, diz e se desdiz, vai e volta. Movimento de gangorra, queda de braço, cabo de guerra. Desde o primeiro parágrafo de Memórias do Subsolo, a cinética da forma se insinua." ${ }^{\circ 9}$

O começo da narrativa já é algo absurdo pelas descrições de fatos da vida de Iefimov. Como é o caso da "herança" deixada pelo italiano, que tem como seu único herdeiro o padrasto de Niétotchka. Toda a circunstância a partir daí lembra, em muito, a própria estilística de Gogol, no tocante à caricatura, uma vez que abundam situações absurdas, o que também revela toda a existência fantasiosa de Iefimov. Aliás, esse traço é muito comum nas primeiras obras de Dostoiévski.

Assim sendo, dadas algumas características de Iefimov, quem é, em boa medida, determinante para o desenvolvimento da narradora, vejamos o que foi, exatamente, essa relação dele com Niétotchka.

Quando, no capítulo dois, Niétotchka enfim passa a nos expor as primeiras lembranças de sua infância, ela mesma ressalta o caráter não muito infantil de tais recordações.

\begin{abstract}
Minhas primeiras recordações são muito tardias, pois datam apenas dos meus oito anos.
Mas daquele momento em diante, de súbito, passei a ter consciência de mim, desenvolvi-me com rapidez imprevista e muitas impressões que nada tinham de infantis gravaram-se em mim de forma estranha. (Dostoiévski:2009, p. 35)
\end{abstract}

Já no início do capítulo dois, Niétotchka procura se justificar em relação ao seu desprezo pela sua própria mãe. Esse movimento de justificação ou, por que não dizer, de "autojustificação" é recorrente durante o desenrolar da narrativa.

Lembro-me de uma tarde, ao crepúsculo; tudo estava espalhado em desordem: as escovas, uns esfregões, nossos pratos de madeira, uma garrafa quebrada, e não sei mais o quê. Minha mãezinha, lembro-me, chorava, extremamente transtornada... Eu achava, sabe Deus por quê, que minha mãe não tinha razão de zangar-se com ele e não o julgava culpado; desejava implorar perdão para ele, suportar em seu lugar qualquer castigo. Tinha um medo terrível de minha mãe (...) (Dostoiévski:2009, p. 36)

Para dar legitimidade a esse movimento de justificação que se desenrolará aos olhos do leitor, a narradora parte, primeiramente, da descrição de uma cena de briga entre os pais, na qual ela sai em defesa de seu padrasto, mostrando, inclusive, um acesso de raiva de sua mãe, que passa a arremessar objetos pela casa. Segundo a narradora, o transtorno de sua mãe é tamanho que 
Niétotchka é pega pelas mãos e arrastada para trás de um biombo. A figura da mãe é apresentada desde o início, nessa relação com a família, de maneira deformada, mostrada como uma mulher louca e transtornada, a ponto de dizer "qualquer coisa em tom amargo e ríspido" para o seu padrasto. Além disso, é interessante notar como ele surge na cena em família.

\begin{abstract}
Esta cena durou umas duas horas, durante as quais, trêmula de impaciência, eu tentava adivinhar com todas as minhas forças como terminaria aquilo. Por fim a briga cessou e minha mãe saiu. Então, meu paizinho chamou-me, beijou-me, afagou-me a cabeça, fez-me sentar em seus joelhos enquanto eu me aconchegava ternamente e com força contra seu peito. Era talvez a primeira carícia de meus pais que eu recebia... Percebi, também, que merecera a benevolência de meu pai porque intercedera por ele e, então, talvez pela primeira vez, surpreendeu-me a ideia de que ele sofria e suportava muita aflição por causa de minha mãezinha. Desde esse dia tal pensamento não me largou mais e deixava-me sempre mais indignada. (Dostoiévski:2009, p. 37)
\end{abstract}

Vale observar, ainda, como até no espaço da narrativa a mãe de Niétotchka está fora da família, na visão que nos dá a narradora. Depois da briga, quem se retira é a mãe, cujo temperamento é de uma "louca", a tal ponto que sai da casa, segundo nos informa as descrições da narradora. Quem fica e acolhe a menina assustada é Iefimov. Outro dado importantíssimo que esta cena nos dá é a lembrança de Niétotchka da primeira manifestação de carinho e amor recebida pelos pais, ou melhor, recebida pela figura do pai. É curioso, tanto quanto conveniente, como a narradora não se lembra do porquê do transtorno de sua mãe, só da imagem de um homem sendo reprimido (é o que se observa na cena) e das carícias de seu pai, partindo, deste modo, a enxergá-la (sua mãe) como a causa do sofrimento de seu padrasto.

\begin{abstract}
Mas até hoje não compreendo por que, exatamente, pudera vir-me a ideia de que meu pai era tão grande sofredor, um homem infeliz! Quem me sugerira isso? De que modo eu, assim tão criança, podia compreender, um pouco que fosse, os seus fracassos pessoais? Compreendia-os, porém, embora tivesse interpretado e transformado tudo em minha imaginação a meu modo; todavia, até hoje não posso explicar a mim mesma de que modo se formou em mim semelhante impressão. (Dostoiévski:2009, pp.37-38)
\end{abstract}

Aqui, Niétotchka passa, mais uma vez, a se justificar. E, então, também joga a problemática para o leitor. Quem atenta para essa característica de autojustificação de algumas personagens dostoievskianas é Grossman. O crítico russo argumenta que

\footnotetext{
Dostoiévski introduziu no romance uma forma nova e fecunda: o diálogo interior. Um dos temas centrais de Dostoiévski é a bifurcação da consciência, a fragmentação da personagem principal. Isto levou o romancista à complexa e oculta dialética da personagem, à discussão muda e aguçada, consistindo na alternância de perguntas e respostas "na mente", isto é, ao autointerrogatório e aos
} 
depoimentos na mesma pessoa. As personagens solitárias e "de subsolo" de Dostoiévski desenvolvem largamente essa forma de argumentação bilateral, com ironia e motejo em relação aos seus próprios pensamentos, colocados sob o controle de uma autocrítica sarcástica. ${ }^{70}$

O estranhamento na obra não se dá somente nessa relação da narradora com a sua mãe, mas também no tratamento dado à infância. No posfácio da segunda edição de Niétotchka Niezvânova, Schnaiderman afirma que "é notável, igualmente, o desmentido que Dostoiévski dá sobre a infância como "idade feliz" e "idade da inocência." narrativa é conduzida por Niétotchka, não somente pelo relato de sua crueldade para com a sua mãe (que a mesma tenta justificar), mas, sobretudo, pela galeria de personagens infantis que aparecem nesta obra de 1840. É como se, nela, Dostoiévski tivesse focado no outro lado da moeda sobre a infância, numa espécie de "lado B" da infância.

Tal é o fato que as próprias relações que se dão entre as crianças chamam a atenção de nós leitores. Pensemos, por exemplo, naquela cena em que Niétochka vai até a venda comprar fermento para a sua mãe, e, ao voltar, acaba caindo no chão, derrubando todo o fermento da xícara. Transeuntes detiveram-se ao redor de mim; uma velhinha tentou levantar-me, mas um menino, que
passou correndo, bateu-me na cabeça com uma chave. (Dostoiévski:2009, p. 39)

Com relação a isso, Pareyson chama a atenção para tal aspecto menos ingênuo dado às crianças que, geralmente, é presente nas obras de Dostoiévski, argumentando que

o fato de que, no elenco dessa tradição [referindo-se aqui à tradição de Santo Agostinho, por exemplo, que vê nas crianças a sensibilidade ao gênio do mal], não se encontre um desmistificador da bondade natural e um adivinho da malícia humana tão infalível quanto Dostoiévski não pode deixar de causar surpresa, porquanto se deva reconhecer que, em mais de uma das suas páginas, aflora a amarga suspeita não só da fácil corruptibilidade, mas também da efetiva depravação da infância. $^{72}$

Em outro momento da narrativa, quando dos delírios de Niétotchka a respeito de um futuro fantástico reservado para ela e o padrasto, eis que surge um fato interessante:

70 L. Grossman. Dostoiévski Artista. Rio de Janeiro. Civilização Brasileira, 1967. P. 52.

71 Posfácio de Niétotchka Niezvânova. Tradução e Posfácio de B. Schnaiderman, 2009. P. 218.

72 Luigi Pareyson. Dostoiévski Filosofia, Romance e Experiência Religiosa. São Paulo. Edusp, 2012. P 194. 
Acreditava que nos tornaríamos imediatamente ricos; eu não seria mais enviada à venda, o que me era penoso, porque as crianças da casa vizinha atormentavam-me quando saía, e eu temia isso terrivelmente... (Dostoiévski:2009, p. 42)

A partir do que foi exposto pela narradora, vemos que eram hostis as relações dela com as outras crianças da vizinhança. Isso mostra um profundo descompasso da menina com a vida objetiva e nas suas relações com o outro, notadamente, na sua relação com as crianças que a rodeavam. Tornando-se, deste modo, sua experiência primeira (da infância) quase que antinatural. A narradora mesma atenta para esse fato de sua vida

Mesmo então, na época sombria de minha estranha infância, no período do desenvolvimento tão antinatural do começo da minha vida, meu coração apertava-se frequentemente de dor e compaixão, e a minha alma era penetrada por sobressaltos, pela confusão e pela dúvida. (Dostoiévski:2009, p. 43)

Sobre esses delírios infantis de Niétotchka, que com frequência aparecem em sua narrativa, a exemplo de como eles surgem e se ligam à própria tessitura do texto, nota-se uma sobreposição de imagens, como a da paisagem luxuosa da São Petersburgo da época com a da miséria escancarada daqueles que habitavam os lugares mais recônditos e insalubres. Tal contraste, porém, converge para um mesmo sentido. Isto é, tanto os delírios da narradora quanto essas paisagens contrastantes de São Petersburgo (que em si têm uma conotação absurda) reforçam aquele caráter fantástico da narrativa e da própria imaginação da menina.

De repente, vi meu pai. Estava no meio da multidão, diante da casa rica, que ficava defronte à nossa. Pertencia a gente importante e estava magnificamente iluminada... (Dostoiévski:2009, p. 39)

Ao acordar no dia seguinte, meu primeiro pensamento, minha primeira preocupação, foi a casa de cortinas vermelhas. Assim que minha mãezinha saiu de casa, trepei na janela e comecei a olhar para aquela casa. Havia muito que ela impressionara a minha curiosidade infantil. Gostava particularmente de contemplá-la ao anoitecer, quando se acendiam as luzes da rua e os reposteiros vermelhos como púrpura brilhavam com reflexos sanguíneos, por trás das vidraças inteiriças da casa intensamente iluminada. À porta paravam geralmente carruagens opulentas, puxadas por magníficos cavalos, que ressumavam orgulho, e tudo atraía a minha curiosidade: os gritos, a azáfama à entrada da casa, as lanternas coloridas das carruagens e as mulheres ricamente vestidas chegavam nelas. Em minha imaginação infantil, tudo isso tomava as proporções de algo imperialmente grandioso, do fantástico dos contos de fadas. Depois daquele encontro com meu paí, junto à rica mansão, esta apresentava-se duplamente maravilhosa e digna de curiosidade. Certas ideias e suposições bizarras surgiram-me na imaginação exaltada." (Id. Ibid., p. 40)

Niétotchka chega a tal ponto em suas fantasias que, ao almejar essa vida feliz ao lado do pai, ela passa a mostrar toda a sua perversidade em relação à mãe. Não somente percebemos o quanto a sua mãe está totalmente deslocada da cena em que é anunciada, como também é possível perceber 
que nenhuma parte da narrativa de Niétotchka foi dedicada a ela. Por exemplo, há vários momentos da narrativa em que a mãe se encontra fora da casa. Praticamente, a narradora se utiliza de três capítulos para falar de Iefimov e da relação de ambos, mas não dedica, em momento algum, uma parte substancial para contar a vida de sua mãe e das experiências com a mesma. A mãe sempre surge "a caminhar pelo quarto" e "falando sozinha, numa espécie de torpor, como de costume".

No início das reminiscências, Niétotchka fala sobre sua mãe ter sido governanta e ter se casado primeiro com um pequeno funcionário, o pai biológico da narradora. Mas, essas são informações muito vagas que, de fato, não nos dizem muita coisa do caráter da mãe. O que sabemos é que ela é uma mulher humilhada e oprimida pelo marido e pelas circunstâncias. Podemos observar a maneira quase que às escondidas como sua mãe surge, causando, às vezes, certa surpresa em Niétotchka. Na verdade, Niétotchka não é exatamente surpreendida. Mais adiante discorreremos sobre o porquê disso, ou melhor, o que de fato essa cena revela.

Até me admirei quando ele se pôs a falar com ela acerca de qualquer coisa; fiquei surpreendida, porque ele quase nunca falava com ela (Dostoiévski:2009, p. 64)

Na realidade, nem ele nem ela conversavam com a mãe. Parece que a mãe, para além dos delírios de Niétotchka, sequer fazia parte da família, ela não é invocada na cena como parte, mas como quem está ali por uma casualidade, como alguém que surge ali de repente. A sua mãe é sempre a pessoa que está fora de casa. Gerando a ideia de uma espécie de não pertencimento à casa, ou à família. É interessante notar que não somente nas fantasias de Niétotchka como, também, na vida real a sua mãe não faz parte da família. E quando, em algum momento da narrativa, há de fato uma interação entre ambas, a narradora se porta sempre de modo hostil

As lágrimas queriam jorrar-me dos olhos, mas eu endurecia-me e me continha. De certo modo, obstinava-me, evitando expressar perante ela o meu sentimento, embora eu própria sofresse com isso. (Dostoiévski:2009, p.44)

Mais adiante, observaremos esse aspecto da narradora também em outra personagem infantil da obra. Quem atenta para esse comportamento de Niétotchka é Joseph Frank. Segundo o autor,

o tema principal da primeira parte, pelo menos no plano puramente moral e psicológico, é o ódio cruel e injusto de uma criança por um de seus pais - um ódio nascido da falsa crença de que essa figura bloqueia o caminho da realização de um artista e do seu acesso à vida de conforto e glórias que viria na esteira do sucesso artístico. A criança, no caso, é uma menina, o objeto do ódio é sua 
mãe, e o artista é seu padrasto. O terrível sentimento de culpa de Niétotchka pelo ódio à sua pobre e infeliz mãe, que trabalhou a vida inteira, e a quem ela roubava para ajudar seu ignóbil pai artista, também pode ser interpretado como um reflexo do sentimento de culpa de Dostoiévski pelo assassinato do pai. $^{73}$

Embora Frank faça uma leitura mais psicanalítica, especialmente freudiana, desse comportamento de Niétotchka, podemos entender o caso também como um reflexo do cinismo da narradora. Do que temos como relato da personalidade do pai de Dostoiévski, tratava-se de um homem muito rígido com a esposa e, sobretudo, com os filhos; tal comportamento não era diferente na relação com os servos de sua propriedade. Culminando, inclusive, em seu assassinato. De maneira alguma, vemos tal personalidade na construção do caráter da mãe de Niétotchka, que justifique o ódio pela sua mãe. Não há passagens na obra que mostrem um comportamento autoritário, ignóbil de sua mãe, ao contrário, suporta tudo, até mesmo o desamor de sua filha.

\begin{abstract}
No mesmo instante, mostrou-se disposta a uma reaproximação com ele, a perdoá-lo pela vida que havia levado, mesmo colocando na balança o crime mais recente, o sacrifício de sua única filha; num acesso de entusiasmo recém-aceso, no arroubo da esperança primeira, estava disposta e relevar-lhe esse crime, rebaixando-o ao nível de uma simples transgressão, uma fraqueja, provocada pela miséria, pela vida imunda, pela situação de desespero. Nela, tudo era arrebatamento, e, naquele instante, tinha prontos já o perdão e uma compaixão sem limites pelo seu aniquilado marido. (Dostoiévski:2009, p.72)
\end{abstract}

Frank afirma acima que Niétotchka tem um "terrível sentimento de culpa" por ser má com a mãe. Mas, aquilo que vislumbramos é, mesmo, o arrependimento da narradora? Nesse sentido, é oportuna a argumentação de Luigi Pareyson sobre o assunto. Para o autor,

a virtude tem um avesso de lama e de torpeza, do qual ela tanto pode ser a superação quanto o encobrimento: quem pode dizer se uma virtude vence verdadeiramente, ou apenas dissimula o mal do qual emerge, se ela o transcende, dele se purificando, ou se ainda está por ele envolvida e manchada? ${ }^{74}$

Mais adiante, falaremos dessa postura de Niétotchka, pensando, principalmente, no movimento de justificação que se dá ao longo de suas memórias.

Nas poucas vezes que a figura da mãe aparece na narrativa, é interessante notar toda uma vida de sofrimento da mesma, de um sofrimento tal que enxergamos uma vida atravessada pela dor, 
unicamente. Sobre esse aspecto da obra, podem ser esclarecedoras as colocações de Pareyson a respeito do tema do sofrimento ${ }^{75}$. Segundo o autor,

o sofrimento inútil é aquele que, ou pelo excesso da dor ou pela incapacidade do paciente, não pode transformar-se nem em via para a purificação e para a redenção, nem em meio de maturação interior [...] Quem o vive é o mero objeto de um destino não menos cruel e injusto do que caprichoso e arbitrário: reduzido ao estado de puro paciente, não pode obter o nome de herói, porque não 'age', mas, certamente, o de mártir, isto é, a testemunha de uma transcendência que opera nele e sobre ele; contudo, pela sua passividade, inconsciência e entrega, permanece um mártir completamente involuntário, no qual o sofrimento fica completamente infrutoso [...] É um sofrimento que não tem outro resultado senão o de produzir mais sofrimento. ${ }^{76}$

O ápice de suas fantasias se dá no momento em que passa a desejar a morte de sua mãe. Ouvindo, certa vez, uma discussão entre os pais, Niétotchka dá atenção a algumas palavras de Iefimov, segundo as quais ele só poderia alcançar a fama e sua plena liberdade quando a esposa morresse. A narradora já tinha uma ideia fixa em sua mente imaginativa e, a partir daí, passa a enfeitar ainda mais os seus delírios infantis

- Tua mãe? Morta? Quando morrer a mãe?- repetia ele, olhando-me perplexo, franzindo as sobrancelhas espessas, com manchas grisalhas, o semblante um pouco alterado. - Que estás dizendo, pobre tola?...

Pôs-se então a recriminar-me e durante muito tempo me disse que eu era uma criança estúpida, que não entendia nada... e não me lembro o que mais; estava muito magoado. (Dostoiévski:2009, pp.47-48)

Ademais, embora não tivesse compreendido desde as primeiras palavras o que ele me dizia, senti, ainda que de modo confuso, que eu havia ofendido minha mãe. Fui presa de horror e medo, e a dúvida se insinuou sorrateira no mais fundo de minha alma. (Dostoiévski:2009, p. 48)

Nota-se, pela postura de Iefimov, quem se mostra perplexo e horrorizado diante dessa atitude da filha em desejar a morte da própria mãe, um movimento peculiar na narrativa. É por meio de Iefimov que a crueldade da narradora vem à tona, colocando-se de maneira clara. Ou seja, a verdade emerge de uma maneira inusitada: é pela boca de um bêbado, de um "disparatado" que ela vem à tona. Como apontado por Chklóvski, podemos dizer que há aí um procedimento de singularização. Segundo o autor,

o objetivo da arte é dar a sensação do objeto como visão e não como reconhecimento; o procedimento da arte é o procedimento da singularização dos objetos e o procedimento que consiste em obscurecer a forma, aumentar a dificuldade e a duração da percepção. ${ }^{77}$

75 A própria narradora se dirige à sua mãe como mártir.

76 Luigi Pareyson. Dostoiévski Filosofia, Romance e Experiência Religiosa. São Paulo. Edusp. Pp. 185-186.

77 V. Chklóvski. “A Arte Como Procedimento”. In: Teoria da Literatura: Formalistas Russos. Porto Alegre. Globo, 
Chklovski afirma ainda que, "quase sempre que há imagem, há singularização. [...] O objetivo da imagem não é tornar mais próxima de nossa compreensão a significação que ela traz, mas criar uma percepção particular do objeto, criar uma visão e não o seu reconhecimento."78

De fato, vemos nos trechos acima o desmascaramento da frieza de Niétotchka, mas o mais importante é que ele surge de uma forma não esperada pelo leitor, há uma quebra das expectativas de como essa verdade deveria aparecer. Pela lógica do automatismo das circunstâncias, e, pensemos aqui, da própria lógica de como são construídos os enredos na obra literária, criou-se uma linha mais ou menos linear (automática) de como seguir para obter seus efeitos estéticos. Por exemplo, é comum que a verdade, em uma história que se nos apresenta, surja de personagens que, de antemão, já foram elaboradas de uma maneira integra, sem tantas contradições, com um caráter desenvolvido de maneira tal que, deste modo, dê sustentação para a "verdade" que elas anunciarão. Assim, a “verdade" deveria surgir dessas pessoas íntegras de caráter. É típico tal procedimento. Mas esse não é o caso de Iefimov, cuja representação é da mentira e do engano. Sobre a construção do enredo e da singularização no paralelismo psicológico, Chklovski argumenta ainda que,

O importante no paralelismo é a sensação de não coincidência de uma semelhança. O objetivo do paralelismo, como em geral o objetivo da imagem, representa a transferência de um objeto de sua percepção habitual para uma esfera de nova percepção; há portanto uma mudança semântica específica. $^{79}$

A inversão, na maneira de construir a personagem portadora da "verdade", dá-se, aqui, na medida em que a verdade é escancarada pela boca de um "disparatado" e não por meio de um personagem íntegro. Iefimov é construído de maneira fantasiosa, julgando-se o melhor violinista não só da Rússia como também do mundo, que vive de mentiras, enganando a todos ao seu redor. Mas também é aquele na narrativa que mostrará para a própria filha toda a sua ignomínia.

Nota-se, pelas próprias palavras da narradora, outro sentimento em jogo nessa relação entre os dois

[...] eu crescia em nossa mansarda, e aos poucos, o meu amor, ou, dizendo melhor, paixão, pois não conheço palavra bastante forte para expressar plenamente o sentimento invencível, torturante, que eu tinha por meu pai [...] Eu tinha apenas um prazer: pensar nele e tê-lo como objeto de meus

1971. P. 45.

78 Idem, p. 50.

79 Idem, p. 54. 
Niétotchka, apesar de se sentir atraída por Iefimov e de se voltar para a história de seu pai, mostrando o afeto que nutria por ele, vez ou outra assinala uma presunção em relação ao mesmo, sobre a qual falaremos mais adiante

Pouco a pouco, senti que era superior a ele, que o subjugava gradualmente, e que, até, lhe era indispensável. Orgulhava-me interiormente com isso, triunfava em meu íntimo e, compreendendo como lhe era necessária, chegava às vezes a ser faceira com ele. (Dostoiévski:2009, P. 58)

Quem atenta para essa relação entre Niétotchka e Iefimov é João Alexandre Barbosa. Ele analisa a cena, na qual Iefímov toca, segundo as palavras da própria narradora, uma música terrível. Em uma leitura mais psicanalítica, mas ainda pensando nessa história com o padrasto, com o qual ela estabelece uma relação instável, caracterizada pela falta de equilíbrio emocional e moral, Barbosa pontua que

tocada pelo padrasto, a música, resume, ou condensa, as contraditórias relações entre ambos, em que o amor e ódio revezam-se vertiginosamente. É precisamente a ambiguidade das interpretações ('mas aquilo não era música...') que instaura o subtexto de grande intensidade psicológica que é possível ler. Toda a dramaticidade que resulta das reações de Niétotchka ao violino de Iefímov não pode ser lida apenas como expressão da protagonista, mas como articulando relações entre as personagens, sobretudo entre ela e o padrasto, que a própria novela foi integrando a seu espaço de ficção. ${ }^{80}$

É interessante as considerações de Pareyson a respeito desse revezamento entre o amor e o ódio na relação de Niétotchka com o padrasto. Segundo o autor,

coisa muito mais difícil é, no amor, separar dedicação e crueldade, e Dostoiévski é indagador agudíssimo e descritor inigualável da dramática ambivalência do amor. Nas suas mulheres ardentes e apaixonadas e nos seus homens fogosos e violentos, não só se alternam, mas também coexistem sentimentos de sincero arrebatamento e de impiedosa hostilidade, de confiante abandono e de esquiva reserva, de desejo de amor e ser amado, de necessidade de sofrer e fazer sofrer, e esses opostos, simultâneos movimentos contudo, tornam-se às vezes tão intensos e exasperados que realizam a terrível copresença da paixão e do ódio. ${ }^{81}$

80 João A. Barbosa. A leitura do Intervalo. São Paulo. Iluminuras, 1990. Pp. 28-29.

81 Luigi Pareyson. Dostoiévski Filosofia, Romance e Experiência Religiosa. São Paulo. Edusp, 2012. P. 127. 
Voltemo-nos, agora, para a relação de Niétotchka com Kátia, que, ao que tudo indica, parece recuperar, de alguma forma, essas relações com Iefimov. 


\title{
2.2 Niétotchka e Kátia
}

Apesar de a narradora dedicar apenas um capítulo a Kátia, é interessante notar a intensidade na relação entre ambas. Percebe-se, primeiramente, uma gradativa evolução nas relações entre as meninas. Primeiro, o choque de Kátia diante de certas peculiaridades de Niétotchka.

Ela estranhava o comportamento nada saudável da narradora, a qual vivia em seu isolamento: “eu ainda estava enfraquecida pela doença, e era quieta, pensativa; os jogos não me alegravam (...) (Dostoiévski:2009, p.104). Niétotchka não se interessava por jogos e vivia presa em seus próprios pensamentos, características essas que, inclusive, não fazem parte do universo infantil. Porém ainda há outra peculiaridade que chama a atenção de Kátia.

Era tão forte aquela atração, eu me entregava com tamanho ardor a esse meu novo sentimento, que ela não poderia deixar de notá-lo, e a princípio isto lhe pareceu estranho, inaudito. Lembro-me de que, de uma feita, no decorrer de certo jogo, não me contive, atirei-me ao seu pescoço e pus-me a beijá-la. (Dostoiévski:2009, p.103)

No decorrer dessas reminiscências sobre Kátia, a própria narradora nos mostra como já tinha, de certa forma, consciência da sua pequena peculiaridade

\begin{abstract}
A princípio, eu me acusei, pensando que realmente houvesse muito de estranho em mim. Mas, embora isto fosse também verdade, eu me atormentava, perplexa: por que não podia fazer amizade com Kátia logo e agradar-lhe para sempre? (Dostoiévski:2009, p.103)
\end{abstract}

Outro fato que chama a atenção do leitor, no tocante a essas particularidades nada infantis de Niétotchka, é tal relação de estranhamento ${ }^{82}$ entre as crianças. Isto é, Niétotchka, ao se aproximar e ganhar a confiança da filha do príncipe, confessa-lhe a sua habitual sensação de desconforto em relação às crianças da vizinhança da sua antiga água-furtada. Revelando, desse modo, uma característica antinatural das crianças em sua primeira idade. Vale observar que é somente dessa forma que elas são invocadas.

\footnotetext{
- Má, como és má! Por que, até agora, não me contaste tudo isso? Eu te amaria tanto, tanto! E doía quando os meninos te batiam na rua?

- Doía.Eu tinha medo deles!

- Uh, malvados! Sabes, Niétotchka, eu também vi um menino bater em outro, na rua. Amanhã vou, quietinha, apanhar o chicote de Falstaff, e, se encontrar um deles, vou bater-lhe tanto, tanto! (Dostoiévski:2009, p.138)
}

82 Fato esse já exposto pela narradora anteriormente e retomado nessas novas relações com Kátia. 
Vemos, não só pelo relato da narradora como também pelo da princesa Kátia, que a obra é povoada dessas singulares crianças em que a ingenuidade parece não ser aquilo, somente, que as constitui.

Porém, mesmo diante dessas peculiaridades de Niétotchka, Kátia passa a se envolver, cada vez mais, com a nova criança que se encontra em sua casa, passando de uma primeira impressão negativa a um amor que vai ganhando intensidade. Isso ocorre a tal ponto que elas se tornam inseparáveis. Antes de prosseguir nessa pequena e intensa aventura das meninas, faz-se necessário entendermos a atmosfera que as cercava e, a partir daí, pensarmos o quê que poderia gerar um desconforto na relação entre elas, que culminaria na separação das duas.

Quando Niétotchka vai morar na casa do Príncipe K., tanto a princesa velhinha ${ }^{83}$ não simpatiza com Niétotchka como também a mãe de Kátia parece não ter se afeiçoado à menina que havia ficado órfã. E mais, via um grande problema na aproximação entre Niétotchka e Kátia.

\begin{abstract}
Deve-se dizer que a princesa estava muito descontente comigo e que me atribuía, bem como à influência do meu gênio sombrio sobre o caráter de sua filha, conforme dizia, toda a transformação ocorrida com Kátia. Ela já nos teria separado há muito, mas adiava isso, sabendo que seria preciso suportar uma discussão séria com o príncipe... (Dostoiévski:2009, p. 121)
\end{abstract}

Vemos que a princesa nota uma transformação em sua filha, que se torna mais calada e pensativa a partir dessa nova sensação que experimenta ao lado da narradora. É interessante essa observação da mãe de Kátia, porque o que se verifica nas lembranças de Niétotchka é a alegria de ambas, principalmente quando a narradora vê os seus afetos sendo correspondidos por Kátia. Ao que tudo indica (pelo relato de Niétotchka), fora um momento feliz para as duas meninas, porém breve. O que, inevitavelmente, chama-nos a atenção é toda essa movimentação das personagens adultas, parecendo que para elas havia algo ali inesperado ou, até, indesejado.

Podemos pensar que a separação das duas meninas foi proposital por dois motivos principais. Primeiramente, Kátia provinha de uma família abastada e importante naquela sociedade do século XIX, e era também filha e herdeira do Príncipe K; ao passo que, Niétotchka tinha uma origem humilde e pertencia à classe dos humilhados e ofendidos. Em segundo lugar, o que, aliás, tem um peso maior, porque parecia haver aí (na relação das duas) algo que fugia da normalidade, algo que soava como patológico e, que, caso se manifestasse, precisava ser extirpado já na infância.

E separar Niétotchka de Kátia foi a forma encontrada para manter, por assim dizer, essa “descendência sadia". Podemos observar esse fato até mesmo nas inquietações da própria Madame Léotard, quem não somente ensinava e educava as duas meninas como também as vigiava, procurando detectar possíveis sinais de "anormalidades" para, assim, poder corrigi-los.

83 Nome este que a própria narradora a atribui. 
Madame Léotard estava incumbida de comunicar todos os passos da pequena princesa. Passou três dias consecutivos a observar-nos, e, nesses três dias, acumulou muito o que contar. Finalmente, foi à presença da princesa e relatou-lhe tudo o que notara: estávamos ambas numa espécie de exaltação; havia três dias que não nos separávamos; beijávamo-nos a cada momento, chorávamos, soltávamos gargalhadas como duas possessas, e, como loucas, tagarelávamos sem cessar, e isso não acontecia antes; ela não sabia a que atribuir tudo aquilo, mas, segundo lhe parecia, a pequena princesa estava atravessando alguma crise doentia e, na sua opinião, seria preferível não andarmos tão unidas.

- Isso não é natural - disse. - Antes, elas eram tão estranhas uma à outra e, confesso, isso me deixava contente. Por menor que seja essa orfãzinha, eu não garanto nada. Está-me compreendendo? Com o leite materno, ela absorveu a sua educação, os seus hábitos e, talvez, as suas regras de conduta. E eu não sei o que o príncipe vê nela. Mil vezes propus mandá-la para um internato.(Dostoiévski: 2009, p. 139)

Madame Léotard tentou a minha defesa, mas a princesa já decidira a nossa separação. Imediatamente, mandou-se chamar Kátia e, no andar térreo, declararam-lhe que não me veria até o domingo seguinte, isto é, durante toda uma semana. (Id. Ibid., pp. 139-140)

Notemos as palavras da própria princesa (no penúltimo excerto acima), quando ela fica sabendo do estreitamento das relações de sua filha com Niétotchka. Quando a princesa diz que "não é natural" essa amizade entre as meninas, sugere-nos que a natureza dessas mesmas relações é antinatural, ou seja, doentia. Para tentarmos compreender melhor essa situação de desconforto por parte da princesa, seria oportuno atentarmos para alguns procedimentos que ocorriam naquelas casas nobres do século XIX, os quais Foucault ressalta em seu trabalho sobre a sexualidade, visto que esses procedimentos eram comuns nos casos em que se identificava alguma "anormalidade". Para Foucault,

as técnicas mais rigorosas foram formadas e, sobretudo, aplicadas em primeiro lugar com mais intensidade nas classes economicamente privilegiadas e politicamente dirigentes. A direção espiritual, o exame de si mesmo, toda a longa elaboração dos pecados da carne, a detecção escrupulosa da concupiscência - todos processos sutis que praticamente não podiam ser acessíveis senão a grupos restritos. Pode-se dizer o mesmo da família como instância de controle e ponto de saturação sexual: foi na família "burguesa", ou "aristocrática", que se problematizou inicialmente a sexualidade das crianças ou dos adolescentes; e nela foi medicalizada a sexualidade feminina; ela foi alertada em primeiro lugar para a patologia possível do sexo, a urgência em vigiá-lo e a necessidade de inventar uma tecnologia racional de correção. Quanto ao adolescente, desperdiçando em prazeres secretos a sua futura substância, e à criança onanista que tanto preocupou médicos e educadores, desde o fim do século XVIII até o fim do século XIX, não era o 
filho do povo, o futuro operário a quem se deveria ensinar as disciplinas do corpo; era o colegial, a criança cercada de serviçais, de preceptores e de governantas, e que corria o risco de comprometer menos uma força física do que capacidades intelectuais, que tinha o dever moral e a obrigação de conservar, para sua família e sua classe, uma descendência sadia. ${ }^{84}$

Segundo Bianchi, "reiteradas vezes, ao falar sobre a concepção de arte, Dostoiévski declarou sua firme convicção de que a base de qualquer criação artística autêntica é constituída pela realidade e que o escritor para o seu ofício, deve conhecê-la a fundo." ${ }^{85}$ Podemos pensar, diante do exposto, que Dostoiévski não somente tinha conhecimento dessas práticas de "cuidados" nas casas aristocráticas, em relação às crianças, como também as transpõem para essa narrativa com alguma finalidade, uma vez que a fala da princesa é bem sugestiva.

Outra pessoa que também fica apreensiva (como vimos anteriormente) com a forte ligação entre as duas meninas é Madame Léotard. Ela, depois que a princesa decide separar Niétotchka e Kátia definitivamente, faz a seguinte observação ao príncipe:

Madame Léotard atormentou-me ao extremo com os seus carinhos. Ao anoitecer, conforme eu soube, ela fora ver o príncipe e dissera-lhe que eu, sem dúvida alguma, iria adoecer pela terceira vez, se não tornasse a ver Kátia, e que ela estava arrependida de ter contado tudo à princesa. (Dostoiévski:2009, p. 140)

Mas o que significava ter contado tudo? O que estava acontecendo entre as meninas que não poderia ser contado? É curiosa essa observação de M. Léotard. Mais adiante, o Príncipe K. procura Niétotchka e tenta consolá-la diante dessa separação forçada, mas falando-lhe ao ouvido, mostrando, com isso, que o caso não poderia ser aludido assim às claras,

[...] de manhã, veio ver-me o príncipe e disse-me ao ouvido que tivesse esperança. Empenhou-se em que a princesa modificasse a sua decisão, mas foi tudo inútil. (Dostoiévski:2009, p. 140)

Mas porque ele não poderia falar em voz alta? Aliás, o príncipe, embora se movimente também com o caso, o faz com a intenção de aproximá-las, divergindo, completamente, da postura da princesa.

- Papa, és um homem tão bom, papa!

- Vocês são umas traquinas! O que aconteceu com vocês? Que amizade é essa? Que amor é esse?

84 Michel Foucault, História da Sexualidade I: A Vontade de Saber. Rio de Janeiro. Edições Graal, 2001, Pp. 113-114.

85 Fátima Bianchi. "O Tema da Submissão Feminina na novela A Dócil”. In: Caderno de Literatura e Cultura Russa, n. 2. Ateliê Editorial. São Paulo, 2008. P. 326 
Nota-se uma peculiaridade no excerto apresentado acima: trata-se da postura do Príncipe K. Ele, ao contrário da princesa, reage de uma maneira muito longe do que seria o habitual. Não vemos ali, naquela conversa entre pai e filha, nenhum sinal de desaprovação dessa relação íntima entre as meninas, tanto que, o próprio encontro de Kátia com Niétotchka só foi possível com a ajuda do príncipe. Vemos, na verdade, uma surpresa do príncipe diante desse amor entre as meninas, o qual lhe suscita questões, no sentido de fazer pensar sobre, mas sem recriminar aquilo que está diante de seus olhos. E parece-nos que ele tem uma função importante na obra.

Voltemos às memórias de Niétotchka para tentarmos entender o porquê de toda essa agitação das personagens motivada por aquela aproximação entre as meninas. Não nos esqueçamos de que Niétotchka tinha uma particularidade que chamou a atenção de Kátia desde o início. Segundo a narradora:

\footnotetext{
Numa palavra, o pequeno romance estava se resolvendo e chegava ao seu desfecho. No terceiro dia após o regresso de Kátia para junto de nós, percebi que ela passou a fitar-me a manhã inteira, com olhos tão lindos e tão prolongadamente... Encontrei diversas vezes aqueles olhares, e cada vez nos ruborizávamos e baixávamos a vista, como se tivéssemos vergonha uma da outra. (Dostoiévski:2009, p. 122)
}

A pergunta que fica é: por que se ruborizavam ao olhar uma para a outra, que tipo de amizade era essa, assim tão especial, a ponto de elas se sentirem envergonhadas? Em outro momento de suas lembranças, chama-nos a atenção o comportamento de Kátia

\begin{abstract}
Mas, no mesmo instante, ergueu-se de um salto e, completamente ruborizada, toda em lágrimas, atirou-se ao meu pescoço. Tinha as faces umedecidas, os lábios túmidos, como cerejinhas, os cachos do cabelo em desordem. Beijava-me como uma possessa, beijava-me o rosto, os olhos, os lábios, o pescoço, os braços; chorava, como se estivesse atacada de histerismo; apertei-me fortemente contra ela, e abraçamo-nos doce e alegremente, como amigas, como amantes, que se encontravam após uma separação prolongada. O coração de Kátia batia com tamanha força que eu ouvia cada pancada. (Dostoiévski:2009, p. 132)
\end{abstract}

A cena vai ganhando tal proporção de sentimentos, os quais estavam há muito tempo ocultados, que se tem a sensação de algo que vai além de um simples sentimento de amizade e que, naturalmente, passa pelo corpo, dada a preocupação da narradora em pontuar cada gesto de Kátia e, sobretudo, cada parte de seu corpo que recebe seus afetos e o calor humano da outra. Depois, notase na cena um crescente de extravasamento das emoções das meninas 
Um instante depois, já eu estava na sua cama; abraçamo-nos e apertamo-nos com ardor. A princesa beijava-me arrebatada. (Dostoiévski:2009, p. 13)

Parece não haver uma espécie de vergonha nesses relatos intensos de amor entre ambas. De tal maneira que não somente ele é relatado assim, sem vergonha, mas, é também encarado deste modo pelas meninas, como algo natural. Kátia mesma chama a atenção para isso:

“Ah, como somos sem-vergonha, Niétotchka! (Dostoiévski:2009, p. 136)

Claro que a afirmativa de Kátia pode conter uma ambiguidade. Isso tanto no sentido de elas terem consciência de algo que deveria causar-lhes algum constrangimento, como no de algo visto de maneira natural e, portanto, sem precisar olhar para isso com alguma reserva. Todavia, notemos como as duas se entregam de corpo e alma a essa nova sensação, sem o menor pudor, com naturalidade.

Wilson Martins, em seu prefácio (Dostoiévski como Romancista) da tradução de Nietótchka pela editora José Olympio, atenta para essa questão, afirmando que

o que há de mais importante em Nietótchka é o arrojo com que Dostoiévski apresenta um caso de amor entre duas adolescentes, sem insinuar a menor ideia de depravação, como se isso constituísse a coisa mais natural do mundo. Não se trata de um amor puramente afetivo, nem das dezenas de significados que essa palavra tem na linguagem comum: o amor entre Nietótchka e Kátia decorre num ambiente de significação sexual inegável, embora inconsciente por parte dos personagens... ${ }^{86}$

Schnaiderman também chama a atenção para a naturalidade de como esse amor entre as meninas é narrado, observando que

Dostoiévski aparece em toda a sua genialidade no episódio do convívio erótico entre Niétotchka e Kátia [...] Os pormenores deste convívio vão num crescendo, aquele "pequeno romance", como o define a narradora, adquire tal intensidade que se torna surpreendente a circunstância de ter sido escrito entre 1846-1849. E o mais inesperado, certamente, é o fato de semelhantes episódios aparecerem numa literatura que era então extremamente pudica em relação a sexo [...] Se tudo se desenvolve num clima de paroxismo, marcado estilisticamente pelo uso de períodos bem mais curtos e pela abundância dos pontos de exclamação, ao mesmo tempo o episódio é narrado como algo natural, não há qualquer alusão a anomalia. Ora, isto contrasta não só com o que se esperava então de um romance russo, mas também com o modo como se encarava na época, pelo menos no

86 Wilson Martins. "Dostoiévski como Romancista”. In: Prefácio de Nietótchka. José Olympio, Rio de Janeiro, 1952. P. 33. 
mundo ocidental, o erotismo infantil e uma atração homossexual. ${ }^{87}$

Já Natália Nunes, em uma análise mais psicanalítica, enxerga na relação das meninas esse componente homossexual, que vai ao encontro da afirmativa acima de Schnaiderman. Segundo a autora,

\begin{abstract}
se no amor infantil de Niétotchka pelo seu padrasto, Dostoiévski apreendeu a verdade de uma erótica que se revela já no amor do rapaz pela mãe e no da menina pelo pai, agora apreende a fase em que a projeção do amor se revela muitas vezes sob o aspecto de uma atração homossexual. Aqui há duas meninas que sentem uma pela outra uma atração em que chega a haver qualquer coisa de libidinoso, pois os seus beijos e afagos não são apenas de amizade pura, estão mesclados de uma sofreguidão sexual. ${ }^{88}$
\end{abstract}

Frank faz a seguinte observação a respeito da relação entre Niétotchka e Kátia: “A influenciável Netotchka, tão carente de afeto, apaixona-se pela beleza de Kátia de uma maneira que deixa as implicações eróticas perfeitamente explícitas." 89

João Alexandre Barbosa, quem também procura entender, por sua vez, esses pares Niétotchka/Iefimov, Niétotchka/Kátia, argumenta que

a ambiguidade das relações entre Niétotchka e Kátia é de tal modo criada pelo escritor que, ao ler essas páginas, o leitor não somente se vê a beira de uma emergente e ardente análise do lesbianismo mas, o que é mais importante, recupera o palimpsesto das relações entre Niétotchka e o padrasto, uma vez que a condição de órfã, de desamparo, exatamente aquilo que de certo modo está inscrito no nome da protagonista, funciona como dispositivo de erotização nas relações com Kátia. ${ }^{90}$

Contudo, entra exatamente aí a questão do desconforto dos adultos em relação às meninas, que tinham receio dos adultos da casa, talvez porque já pressentissem um julgamento desfavorável diante daquela nova sensação que elas experimentavam

Tínhamos medo de que nos surpreendessem quando nos beijávamos (...) (Dostoiévski:2009, p.

87 Boris Schnaiderman. Posfácio de Niétotchka Niezvânova. P. 218.

88 Natália Nunes. "Novelas da Juventude" e "Prólogo Geral". In: Obras Completas, VI. Ed. Nova Aguilar, R J, 1995. P. 149.

89 Joseph Frank. Dostoiévski: As Sementes da Revolta, 1821-1849. São Paulo. Edusp, 2008. P. 452.

90 João A. Barbosa. A leitura do Intervalo. São Paulo. Iluminuras, 1990. P. 29. 
É interessante observarmos, mesmo antes, que Niétotchka fala diretamente com o leitor, aliás, típico deste tipo de personagem

\begin{abstract}
Mas eu quase não compreendia o que estava acontecendo comigo. Tudo se perturbava em mim com uma sensação nova, inexplicável, e não haverá exagero de minha parte se eu disser que então sofria e me atormentava com essa nova sensação. Resumindo - e perdoem-me estas palavras - eu estava apaixonada por minha Kátia. (Dostoiévski:2009, p. 115)
\end{abstract}

Mas por que Niétotchka se dirigiria a seu leitor assim? O que será que nós leitores poderíamos presumir diante desse relato tão minucioso e intenso sobre as meninas? Também chama-nos a atenção a maneira como a narradora se refere, às vezes, a alguma característica física de Kátia, mostrando, possivelmente, o quanto certas qualidades físicas dessa última a estimulavam

[...] apertou com muita seriedade os labiozinhos rechonchudos... (Dostoiévski:2009, p.103)

[...] Tinha as faces umedecidas, os lábios túmidos, como cerejinhas... (Dostoiévski:2009, p.132)

Voltando às colocações de Barbosa, sobre o quanto essa relação de Niétotchka com Kátia recupera, de certa forma, o palimpsesto de sua relação com o padrasto. Podemos entender, ainda, uma observação que a própria narradora faz em relação aos períodos de sua doença. Segundo ela, são dois os momentos:

Foi o segundo e último período de minha doença (Dostoiévski:2009, p. 99)

Antes de nos atermos a essa fala de Niétotchka que, aliás, inicia a quinta parte do livro (assim reestruturado por Dostoiévski, quando da republicação em 1860), vejamos qual teria sido o primeiro período da doença da nossa narradora. Na segunda parte, quando Niétotchka passa a relatar as suas primeiras impressões e lembranças da sua infância datadas, de acordo com ela, a partir dos oito anos, chama-nos a atenção a contradição que se estabelece, ao mesmo tempo em que Niétotchka tenta confundir a nós, leitores.

Minhas primeiras recordações são muito tardias, pois datam apenas dos meus oito anos. [...] É verdade que posso, como em sonho, evocar também certos fatos anteriores: uma lamparina sempre acesa num canto escuro, junto a um velho ícone; certa vez em que fui atropelada na rua por um cavalo, fato devido ao qual, segundo me contaram mais tarde, passei de cama por três meses; e como ainda, no decorrer dessa doença, acordei uma noite, ao lado de minha mãezinha... e de repente me assustei com os meus sonhos doentios, com a quietude noturna e com o ruído dos camundongos arranhando algo a um canto, e tremi de medo a noite inteira, encolhendo-me sob o cobertor sem ousar acordar minha mãezinha, do que concluo temê-la então mais que tudo. 
Primeiro, a narradora afirma que só a partir dos oito anos é que de fato passa a se lembrar das coisas que lhe sucederam. Logo em seguida, no entanto, ela passa a jogar com o leitor, fazendo supor que é possível também, “como em sonho”, lembrar-se de fatos anteriores. É, então, mais uma das artimanhas discursivas de Niétotchka para dissimular suas verdadeiras intenções. Nesse caso, ela quer nos fazer crer que apenas tardiamente, a partir dos seus oito anos, é que suas lembranças brotam, quando, na verdade, certos fatos já estavam gravados na sua memória. Ou melhor, certas lembranças anteriores diziam muito sobre a sua "doença".

Corrobora para afirmarmos isso o fato que Niétotchka muda de tom ao descrever essas que seriam lembranças anteriores aos seus oito anos. Primeiramente, ela descreve-as com imprecisão, usando expressões como "certos fatos" e "certa vez". Mas, em um dado momento de seu discurso, ela precisa um fato e afirma que "uma noite", ao lado de sua mãe, assustou-se com os seus sonhos doentios.

É interessante notar que a figura do padrasto não aparece, em nenhum momento nesse primeiro relato da sua doença. Porém o que fica subentendido nessas reminiscências de Niétotchka, que seriam anteriores aos seus oito anos é um mal-estar em relação à sua mãe, o que nos remete, inevitavelmente, à sua relação com o padrasto, que seria a causa de seus "sonhos doentios".

Podemos pensar, assim, que o primeiro período da doença de Niétotchka se dá na época dessa relação "estranha" com Iefimov, uma vez que é no capítulo dedicado a Iefimov que a narradora nos põe a par dessa relação tão íntima entre ambos, dizendo:

\footnotetext{
A partir desse instante experimentei por meu pai um amor sem limites, um amor estranho que não parecia infantil (Dostoiévski:2009, p. 37)
}

O segundo período, como exposto acima, de acordo com as próprias palavras da narradora, embora ela o diga de maneira implícita, seria aquele em que Niétotchka inicia sua relação com Kátia, o que acontece no quinto capítulo. Ana (Niétotchka) também narra as suas aventuras amorosas com Kátia. Notamos, de igual maneira, como vimos em seu contato com Iefimov, uma relação exacerbada com Kátia. Ana passa a ter atitudes que vão além do puro sentimento juvenil, se assemelhando mais a uma escrava, sempre disponível a sua amada, do que a uma jovem que experiencia uma relação afetuosa nova. Niétotchka se transfigura, então, em uma pessoa possessiva, obsessiva, em relação a Kátia.

O meu amor por Kátia chegava a assumir uma forma estranha. De uma feita, tirei-lhe às 
escondidas um lenço, de outra vez uma fitinha com que ela costumava prender o cabelo, e durante noites inteiras os beijei, coberta de lágrimas. [...]

Lembro-me de que, às vezes, acordava de noite, levantava-me da cama e acercava-me na ponta dos pés da pequena princesa. Ficava contemplando horas seguidas o sono de Kátia, à luz fraca de nosso velador; por vezes, sentava-me em sua cama, inclinava-me sobre o seu rosto e sentia-lhe o hálito quente. Bem de leve, trêmula de medo, beijava-lhe as mãozinhas, os ombrinhos, os cabelos e o pezinho, se este aparecia sob o cobertor. (Dostoiévski:2009, p. 120)

Notemos o final do parágrafo que antecede este último excerto apresentado acima

Desse modo, as impressões novas expulsavam pouco a pouco as antigas, e as lembranças de meu triste passado, substituídas em mim por uma vida nova, perderam a sua força doentia. (Dostoiévski:2009, p.120)

Aqui, Niétotchka vê as suas "fases da doença" (por assim dizer) como "novas", que remetem a Kátia; e como "antigas", as quais estão relacionadas ao padrasto. No entanto, mais uma vez, ela tenta confundir o leitor. Pois, ao dizer que as lembranças tristes que se ligam às suas impressões antigas, associadas ao padrasto, tinham uma força doentia e, portanto, sua nova experiência estaria isenta de qualquer forma doentia, ela mesma se contradiz no parágrafo seguinte, onde descreve alguns momentos de sua obsessão por Kátia, chegando a ficar "trêmula de medo" ao beijar o corpo da princesa enquanto a mesma dormia.

Desse modo, como pode a nossa narradora afirmar que experiencia uma vida nova, sem ter nada de "doentio" (pensando, aqui, nessa exacerbação do seu desejo), ao mesmo tempo em que nos põe a par de circunstâncias extremamente exacerbadas, que fogem de qualquer normalidade? Em outras palavras, ela está, o tempo todo, se relacionando de maneira obsessiva com o outro, dado o seu caráter duplo, contraditório. Nesse sentido, quando Ana nega este seu estado "doentio" por meio de seu discurso, logo em seguida o reafirma por meio de seus atos, o que inevitavelmente nos remete ao procedimento da demonstração através da opinião do contrário de Skaftymov." $" 91$

A partir do que foi exposto, podemos pensar que o livro é dividido, de fato, em duas partes. A primeira parte se relaciona ao primeiro período da "doença" de Niétotchka, vinculado a Iefimov. A segunda parte, por sua vez, diz respeito ao segundo período de sua "doença", como a narradora mesma salienta, associado ao seu amor exacerbado por Kátia. É interessante notar que esse amor "estranho" que Ana nutre por ambos os personagens, naqueles dois períodos distintos, nos faz pensar, inevitavelmente, sobre a natureza dessas relações. Ou, melhor, podemos pensar por que a própria narradora nos coloca diante dessas relações como se fossem uma "doença". É sabido que no

91 José Antonio Hita Jiménez. NUEVA VISIÓN DE LA OBRA DE DOSTOIEVSKI. Universidad de Granada. 2003. P.53. 
século XIX, a homoafetividade não era vista com bons olhos, menos ainda naturalizada, quem dirá uma relação incestuosa entre um pai e uma filha. Embora Iefimov seja padrasto, e não pai de Niétotchka, o fato é que a ideia, ou melhor, a imagem de pai é muito forte e representativa na narrativa. Assim, tornam-se doentias e patológicas essas relações de Niétotchka porque estavam à margem da sociedade e, então, eram recriminadas. É aí que se pode perceber um diálogo com os leitores da época. Niétotchka sabe que a história que ela narra não é natural para os seus leitores.

E pensando, ainda, nas considerações dos críticos elencados acima a respeito da homoafetividade entre as duas meninas, é interessante pensarmos também em como, diante da censura da época, esse aspecto surge na obra.

É sabido que, por mais que tenha sido o século XIX o século de ouro da literatura russa, a censura foi bem rígida nesse momento. Vários escritores procuraram transmitir, por meio de suas obras, sua maneira de ver o mundo e a sociedade, e, muitas vezes, utilizavam-se delas para fazer uma crítica à sociedade daquela época. E, como precisavam passar pela censura da época, esses escritores russos se valiam de vários meios, de vários artifícios para transmitir aquilo que eles julgavam necessário. Nesta obra aqui analisada, Dostoiévski não foi uma exceção.

Quando Schnaiderman afirma que a questão da homoafetividade em Niétotchka Niezvânova surge de maneira naturalizada, podemos pensar que isso só pôde ter se apresentado de tal forma graças à maneira como Dostoiévski aborda a questão. Dostoiévski localiza essa relação homoafetiva na infância. A infância, de certa forma, é um momento das descobertas e das incertezas; e, ao problematizar a homoafetividade nessa primeira fase da vida do ser humano, o autor russo conseguiu deslocar a atenção da crítica e de alguns de seus leitores mais desatentos. Esses (pelo visto) viam naquilo que é narrado na obra, sobre essa sexualidade, somente impressões infantis de uma menina, típicas da idade dela, e não uma manifestação de homoafetividade por parte da narradora.

A consequência de tal procedimento foi um olhar menos atento e crítico por parte da censura, visto que, de maneira geral, todos têm para si a infância e a adolescência como períodos de transição e que não se deve dar muita atenção para o que se manifesta ali. Por exemplo, Nunes ${ }^{92}$ acredita ser muito comum essa atração homoafetiva se manifestar no período da adolescência.

Dostoiévski foi tão perspicaz ao abordar a questão, alocando-a na infância de Niétotchka (conseguindo, deste modo, desviar a atenção da censura), que pôde, mais tarde, trazer novamente à tona a questão em uma de suas últimas obras, $O$ Adolescente. Ele o fez sem levantar maiores suspeitas, uma vez que aborda o tema localizando-o igualmente na adolescência do protagonista dessa obra. O período em que Dostoiévski enfatiza a homoafetividade, isto é, na infância, parece

92 Natália Nunes. "Novelas da Juventude" e "Prólogo Geral". In: Obras Completas, VI. Ed. Nova Aguilar, Rio de Janeiro, 1995. P. 150. 
ter sido determinante para se desviar da crítica de seu tempo e abordar a questão com mais honestidade.

No próximo item, nos debruçaremos sobre a relação da narradora com o Príncipe K. que parece ter encontrado nessa relação mais harmonia (embora passageira), contrariando, assim, uma sequência de relações ambíguas que se estabelece em sua vida. 


\subsection{Niétotchka e Príncipe K.}

Em Niétotchka Niezvânova, um romance inacabado de Dostoiévski chama a atenção a elaboração de uma personagem: o Príncipe K. Na narrativa, esse personagem é aquele quem, de certa forma, adota Niétotchka quando ela fica desamparada pela perda de seus pais. Numa leitura mais atenta, e seguindo certas brechas que a própria narradora nos dá, percebemos que se trata de um homem dotado de grandes qualidades humanas, desde o primeiro momento em que a narradora nos põe em contato com ele (aliás, muito antes de adotá-la)

B. conta que, naquela mesma tarde, antes do anoitecer, encontrou-se com o Príncipe K., diletante famoso, homem que amava e compreendia profundamente a arte. Caminhavam lado a lado, fazendo comentários sobre o artista recém-chegado, e, de repente, dobrando uma esquina, B. viu meu pai, que estava parado junto à janela de uma loja, e examinava detidamente um pequeno cartaz ali pregado, onde se anunciava em letras graúdas, o concerto de $\mathrm{S}$.

- O senhor está vendo aquele homem? disse B., indicando meu pai.

- Quem é? - perguntou o príncipe.

- O senhor já ouviu falar dele. É aquele mesmo Iefimov, de quem lhe falei mais de uma vez, e a quem o senhor chegou mesmo a proteger há tempos. (Dostoiévski: 2009, pp. 60-61)

No trecho selecionado acima, notamos uma peculiaridade do Príncipe K.: era um homem que amava e compreendia profundamente a arte. A própria narrativa vai nos dando brechas sobre quais ideias estão por trás das personagens. Niétotchka sempre tem a sensação de estar diante de um homem íntegro, bom e justo.

Entre as pessoas que de raro em raro vinham ver-me quando me achava ainda doente e de cama, além do médico velhinho, impressionou-me principalmente o rosto de um homem, já entrado em anos, muito sério; mas, ao mesmo tempo, era tão bondoso, e me olhava com uma tão profunda compaixão! Gostei mais de seu rosto que de todos os outros... Era realmente o Príncipe K. (Dostoiévski: 2009, p. 86)

Não obstante, também verificamos que será este personagem quem questionará a legitimidade de Rousseau em se tratando de educação.

\footnotetext{
- Vejamos uma coisa - começou dizendo a Madame Léotard. - O que é que a senhora anda fazendo? Como foi que agiu assim com uma pobre criança? É um ato bárbaro, completamente bárbaro, uma ação digna dos citas! Uma criança fraca, doente, uma menina sonhadora e assustadiça, imaginativa, e encerrá-la num quarto escuro, por uma noite inteira! Isto significa destruí-la! A senhora não sabe a sua história? É o que lhe digo, senhora: trata-se de um ato bárbaro, desumano! E como se pode aplicar semelhante castigo? Quem inventou, quem podia ter inventado esse castigo?

A pobre Madame Léotard, perturbada, com lágrimas nos olhos, começou a explicar-lhe todo o caso, disse que me esquecera, que sua filha chegara de Moscou, que o castigo em si é coisa boa, se dura pouco, e que o próprio Jean-Jacques Rousseau dissera algo parecido.
} 
- Jean-Jacques Rousseau, minha senhora! Mas Jean-Jacques não podia dizer isso. Jean-Jacques não é autoridade, Jean-Jacques Rousseau não devia ousar falar de educação, não tinha nenhum direito de falar disso. Jean-Jacques Rousseau renegou os próprios filhos, minha senhora! Jean-Jacques era um homem ruim, senhora!

- Jean-Jacques Rousseau! Jean-Jacques Rousseau, um homem ruim! Príncipe! Príncipe! O que está dizendo?

E Madame Léotard ficou toda vermelha.

Era uma mulher maravilhosa e, antes de tudo, não gostava de ficar magoada; mas tocar em alguns dos seus prediletos, inquietar a sombra clássica de Corneille, de Racine, ofender Voltaire, chamar Jean-Jacques Rousseau de homem ruim, um bárbaro, meu Deus! (...) (Dostoiévski: 2009, pp. 130131)

Tal embate com Rousseau pode estar ligado também à questão dos eslavófilos e ocidentalistas, que ganhou muita força no século XIX. É sabido que Dostoiévski sempre teve uma postura de desconfiança quanto aos "milagres econômicos" na Europa, e, principalmente, à ideia de uma Europa "civilizada" em contrapartida de uma Rússia "atrasada". Dostoiévski, por meio de sua literatura, desmascara esta ideia de superioridade da Europa, mostrando todas as suas contradições. Memórias do Subsolo, por exemplo, é um tapa na cara de todas essas ideias de racionalidade, que começam a entrar e ganhar espaço na Rússia do século XIX. E, sendo assim, o autor russo passou a ser identificado com os eslavófilos, uma vez que procurava valorizar aquilo que dizia respeito aos próprios russos, aquilo que eles tinham de mais original, provindo de sua ancestralidade eslava.

É sabido, também, que Rousseau era um grande representante daquela cultura europeia, mais precisamente, era representante da ideia da razão ser a medida de todas as coisas. Ideia esta que Dostoiévski refutou em várias obras, inclusive, ridicularizando-a, com o intuito de mostrar que a vida dos homens não poderia se pautar exclusivamente na razão, que ela, por si só, não resolveria todas as inquietudes do homem. Podemos notar certa ironia da própria narradora quando passa a nos contar como foi a discussão envolvendo o Princípe K. e a Madame Léotard.

Era uma mulher maravilhosa e, antes de tudo, não gostava de ficar magoada; mas tocar em alguns dos seus prediletos, inquietar a sombra clássica de Corneille, de Racine, ofender Voltaire, chamar Jean-Jacques Rousseau de homem ruim, um bárbaro, meu Deus! Lágrimas apareceram nos olhos de Madame Léotard; a velhinha tremia de perturbação. (Dostoiévski: 2009, p. 131)

Niétotchka se ajusta ao discurso do Príncipe K. em vez de se ajustar ao discurso e à indignação de Madame Léotard. E isso a aproxima do discurso de Dostoiévski, da visão antiocidentalista dele.

Outro aspecto desse personagem, que não aprofundaremos neste trabalho, é a sua religiosidade, trata-se de um cristão ortodoxo russo.

Levantei a cabeça: era o príncipe; seu rosto expressava profunda simpatia e compaixão; mas eu o olhei com um ar tão abalado, tão infeliz, que as lágrimas apareceram-lhe nos olhos grandes e azuis. 
- Pobre orfãzinha! - disse, afagando-me a cabeça.

(...)

- Minha filha, o que tens, minha querida, pobre Niétotchka? O que tens?

- Onde está minha mamãe? Onde está minha mamãe? - gritei, soluçando alto, não tendo mais forças para ocultar a minha angústia e caindo de joelhos, sem forças, diante dele.

- Onde está a minha mamãe? Meu querido, diga-me onde está minha mamãe?

- Perdoa-me, minha filha!... Ah, minha pobre menina! E fui eu que lembrei isto... O que fiz! Vamos, vem comigo, Niétotchka, vem comigo.

Agarrou-me a mão e conduziu-me rapidamente consigo. Estava abalado até o mais fundo de seu ser. Chegamos a um quarto que eu não vira até então.

Era o oratório. Escurecia. A luz dos candeeiros refletia-se vivamente nos paramentos de ouro e as pedras preciosas das imagens. Sob os envoltórios brilhantes, espiavam os semblantes baços dos santos. Tudo ali era tão diferente dos demais quartos, tão misterioso e sombrio que fiquei impressionada e não sei que susto me invadiu o coração. Além disso, meu estado de ânimo era tão doentio! O príncipe logo fez com que me ajoelhasse diante da imagem da Mãe de Deus, e ajoelhou-se ao meu lado...

- Reza, minha filha, reza; vamos rezar os dois! - disse com voz suave e entrecortada. (Dostoiévski: 2009, pp. 94-95)

Sobre essa questão do cristianismo ortodoxo russo é importante a colocação de Berdiaev que acredita na ideia de que "a aristocracia espiritual tem uma missão profética que cumprir, no amplo sentido da palavra: a de atuar em serviço de um porvir melhor, de suscitar o espírito de uma nova vida, de criar valores novos. ${ }^{993}$ Podemos entender o personagem Príncipe K. como uma espécie de “aristocrata espiritual” (usando aqui um termo do próprio Berdiaev). O Príncipe K., em todos os momentos que surge na narrativa, está sempre disposto a ajudar o outro, como uma verdadeira missão, e não somente no sentido material, mas, sobretudo, no sentido espiritual.

Isso, aliás, fica bem visível na cena acima, onde, por compaixão a Niétotchka, ele a leva para um oratório de sua casa com a intenção de fazê-la orar para que, desse modo, ela tivesse paz em seu espírito desconsolado pela perda de seus pais. O Príncipe K., generosamente e verdadeiramente, quer arrancar aquela dor da criança humilhada e ofendida, em um gesto de quem quer "suscitar o espírito de uma nova vida".

Voltando à questão da construção do personagem Príncipe K., o fato é que, já naquele período da década de 40 do século XIX, Dostoiévski o elabora como um verdadeiro cristão ortodoxo russo. Além disso, ganha uma visível e crescente legitimidade na narrativa. Aqui, entra uma questão importantíssima: da mesma forma que o cristianismo ortodoxo do Príncipe K. ganha legitimidade na narrativa, nela também há em pé de igualdade, o discurso ambíguo de Niétotchka. Diante disso, podemos pensar na interação de ideias a que Bakhtin se refere. Segundo o autor, "a categoria fundamental da visão artística de Dostoiévski não é a de formação, mas a de coexistência e interação. ${ }^{94}$ Bakhtin cita Grossman, quem reitera esse procedimento artístico de Dostoiévski que também é visto em Niétotchka Niezvânova. L. Grossman afirma, ainda, que "Dostoiévski coaduna os contrários." 95 Podemos pensar, assim, que essa crescente legitimidade que tem o cristianismo

93 Nicolai Berdiaev. La Afirmación Cristiana y la Realidad Social Contemporánea. México. Ediciones Alba, 1936. P. 144.

94 Mikhail Bakhtin. Problemas da Poética de Dostoiévski. Forense Universitária. Rio de Janeiro, 2013. P. 31.

95 Idem, p. 14. 
ortodoxo russo por parte do Príncipe K. se coaduna, por exemplo, com as próprias confissões de Niétotchka sobre sua paixão por Kátia. Portanto, são visões de mundo distintas que coexistem na narrativa.

A análise da relação de Niétotchka com o Príncipe K. se limitará a apenas essas colocações, uma vez que a própria narradora afirma que, depois, voltará a falar dessa personagem que ela mesma julga importante. Contudo, isso não acontece. Para nós leitores ficam, apenas, essas observações e impressões. E, entre elas, uma impressão meio vaga, que escapa a nossa compreensão, do último contato (de que temos notícia) com o Príncipe K. já na casa de Aleksandra Mikháilovna, que manterá uma relação afetuosa, porém complexa, com Niétotchka. Falaremos melhor dessa relação a seguir. 


\subsection{Niétotchka e Aleksandra Mikháilovna}

Antes de nos estendermos sobre a relação de Aleksandra com Niétotchka, é necessário observarmos como a própria narradora faz, por meio do seu discurso, uma clara distinção entre o seu amor por Kátia e por Aleksandra. Já no início de suas lembranças na casa da sua benfeitora (Niétotchka se refere a ela assim), a narradora pontua a natureza desse novo amor em sua vida.

Ligou-se a mim de toda a alma, amou-me como uma filha, e eu, com lágrimas ainda frescas, devido à minha separação de Kátia, e com o coração ainda dolorido, atirei-me avidamente nos braços maternais de minha benfeitora. A partir de então, não mais cessou o amor ardente que eu lhe dedicava. Era para mim a mãe, a irmã, a amiga; substituiu tudo o que eu tinha no mundo e acalentou-me a juventude. (Dostoiévski:2009, p. 146)

Os adjetivos utilizados por Niétotchka, tais como "maternal" chamam a atenção porque diferem, em boa medida, das palavras usadas pela mesma ao se referir ao seu amor por Kátia. Em relação a essa última, vale lembrar que, para Niétotchka, quando ambas se beijavam, faziam-no “como amantes". As cenas com Kátia são completamente diferentes em relação às cenas apresentadas aqui. É óbvio que há uma carência de Niétotchka, que vai se imiscuindo por toda a narrativa, a qual, inclusive, joga a narradora em várias relações muitas vezes ambíguas. Mas, não aparecem, em nenhum momento da narrativa, na sua relação com Aleksandra Mikháilovna, insinuações de paixão ou de que elas se viam enquanto amantes, entendimento esse que Niétotchka tinha na sua relação com Kátia.

Não podemos tomar o amor despertado pelas personagens com quem Niétotchka entra em contato ao longo de sua vida como uma única forma de amor. Ela experimenta várias formas de amor. É muito claro o que vemos na sua relação com Aleksandra. Para a narradora, ela era "a mãe, a irmã, a amiga".

Nota-se um movimento singular no contato de Niétotchka com Aleksandra, nesse momento da narrativa. Há um movimento, aqui, de retorno ao início da sua narrativa. Porém, voltemos para o período anterior, quando ela se refere a Kátia. Parece, pelo que é exposto a nós leitores, que houve um tempo intermediário nessa quase constância de seu caráter ambíguo. Ou seja, podemos pensar que o contato com Kátia foi um período curto de relativa tranquilidade para a narradora, sem tantas oscilações, por assim dizer, de felicidade

Assim passou aquele dia e o seguinte. Eu temia morrer de júbilo, e a felicidade fazia-me perder o fôlego. (Dostoiévski:2009, p. 139)

Quando da sua separação de Kátia e ao ter contato com a Aleksandra, a sua nova protetora, as 
coisas parecem voltar ao seu estado anterior, nas palavras de Niétotchka:

Minha vida entrou, de chofre, numa espécie de quietação, e, quando completei dezesseis anos, foi como se eu tornasse a voltar a mim (...) (Dostoiévski:2009, p. 142)

Priscila Marques, em seu trabalho sobre Crime e Castigo, traz para o seu texto algumas considerações de Rowe (1972), as quais são muito importantes para entendermos esse movimento observado em Niétotchka Niezvânova. Rowe argumenta que "Dostoiévski cria efeitos antinômicos por meio de uma formulação em três estágios, a qual se assemelha ao movimento de um pêndulo de um lado a outro e, por fim, parcialmente de volta (ROWE, 1972, p.287)"96. Segundo Marques,

tal padrão antinômico se reflete tanto em episódios do romance [aqui a autora se refere a Crime $e$ Castigo], quanto no texto como um todo, e tem por função [aqui ela se utiliza das palavras de Rowe] 'promover harmonia à caracterização, ambivalência emocional, e uma tênue relação entre ilusão e realidade.' (ROWE, 1972, p. 295) ${ }^{97}$

Podemos pensar que há, na narrativa, essa espécie de movimento pendular, proposto por Rowe. Isso porque não são raras as vezes em que Niétotchka sente esse tão conhecido desconforto em sua nova existência, inclusive, assemelhando esse novo momento na casa de Aleksandra com o antigo na sua água-furtada

Às vezes - e isso acontecia com frequência crescente - experimentava uma estranha necessidade de ficar sozinha e pensar, pensar sempre: eram momentos parecidos com os do tempo em que ainda morava em casa dos meus pais e em que, antes de me afeiçoar a meu pai, passara um ano inteiro pensando, considerando tudo, prestando atenção, do meu canto, ao mundo de Deus, de jeito que, por fim, tornara-me completamente selvagem, em meio aos espectros fantásticos, por mim mesma criados. (Dostoiévski:2009, p.157)

São por essas fissuras na obra, pela maneira da narradora expor todo o caso de suas relações e oscilações de sentimento, que percebemos o movimento pendular que se impõe na narrativa. Pelo menos, até onde temos acesso, já que as suas memórias são interrompidas. Chama a atenção, além disso, a crescente indiferença a tudo, mostrando, todavia, um aparente ego superestimado.

Uma fria indiferença substituiu o ardor íntimo e inexperiente. Até os meus dons artísticos, que despertavam tamanho entusiasmo em todos aqueles que eu amava, perderam a minha simpatia e eu os desprezei com insensibilidade. Nada me divertia, e até por Aleksandra Mikháilovna eu já sentia certa indiferença fria, de que eu própria me acusava, pois não podia deixar de ter consciência dela.

96 Priscila Marques. Polifonia e Emoções: Um estudo sobre a construção da subjetividade em Crime e Castigo de Dostoiéviski. São Paulo. 2010. Dissertação. P125.

97 Idem. Ibidem. 
Percebemos, ainda, um crescente sentimento de repulsa de Niétotchka por Piotr, marido de Aleksandra. Na cena em que a narradora vai esmiuçando tudo o que implica a figura de Piotr, por meio de seu retrato na parede, notamos uma situação que, repentinamente, traz uma espécie de iluminação sobre o verdadeiro caráter do personagem.

\begin{abstract}
Queria encontrar algo, como se esperasse achar a solução das minhas dúvidas, e, lembro-me, o que mais me impressionou no retrato foram os olhos. Impressionou-me, naquele instante, o fato de eu não ter visto quase nunca os olhos daquele homem: ele ocultava-os sempre por trás dos óculos.

Já desde criança eu não gostava do olhar dele, em consequência de uma prevenção incompreensível e estranha... De repente, pareceu-me que os olhos do retrato se desviavam, confusos, a fim de fugir do meu olhar penetrante e inquiridor, que se esforçavam por evitá-lo, que havia mentira naqueles olhos (...) (Dostoiévski:2009, p.182)
\end{abstract}

Aliás, esse recurso de se investigar o olhar é muito utilizado por Dostoiévski e constitui uma marca essencial em seus romances. Pensemos, por exemplo, em O Idiota, cuja trama se desenvolve, particularmente e magistralmente, nesse jogo de olhares entre as personagens. Marques também chama a atenção para esse aspecto quando analisa uma cena em que Raskólnikov observa Sônia, afirmando que "tal observação é de grande importância, considerando o status que a descrição do olhar tem na narrativa dostoievskiana." ${ }^{98}$. A autora cita Rosenshield quem corrobora a importância de tal recurso. O autor salienta que Dostoiévski "frequentemente usa os olhos como espelhos simbólicos da alma." ${ }^{99}$. O retrato de Piotr surge aí na narrativa como uma forma de revelação de seu verdadeiro caráter.

Mais adiante na narrativa, em uma das cenas finais do romance, quando Niétotchka surpreende Piotr se examinando no espelho, esse recurso toma tal dimensão que, não somente Piotr lança sua imagem transformada, distorcida no espelho para Niétotchka (que o observa de longe) como também a lança para si mesmo. Emergindo, desse modo, toda a sua verdadeira face ocultada, que lhe causa igual desconforto

[...] Exatamente como agora, ele detivera-se diante do espelho, e eu estremecera, com um sentimento indefinido, que nada tinha de infantil. A impressão que tive, então, foi a de que ele mudava de semblante. Pelo menos, eu via-lhe claramente o sorriso no rosto, antes que ele se aproximasse do espelho; um riso até, coisa que jamais lhe notara antes, pois (lembro-me de que isso me impressionou mais que tudo) ele nunca ria em presença de Aleksandra Mikháilovna. De súbito, mal olhou para o espelho, o seu rosto modificou-se completamente. O sorriso desapareceu, como se obedecesse a uma ordem, e, em lugar dele, apareceu uma expressão amarga, como se esta, até então, estivesse forçando a saída de dentro do seu coração, uma expressão que nenhuma força humana seria capaz de ocultar, apesar de todos os esforços que se fizessem por magnanimidade de caráter; aquela expressão entortou-lhe os lábios, uma dor convulsiva fez com que lhe surgissem 
rugas sobre a testa, contraindo-lhe as sobrancelhas. O seu olhar ocultou-se sombriamente sob os óculos; em suma, num átimo, como que obedecendo a uma ordem de comando, Piotr Aleksândrovitch tornou-se uma pessoa completamente diversa. (Dostoiévski:2009, p. 189)

Ainda sobre o pressentimento de Niétotchka sobre o caráter sombrio de Piotr, ou seja, sobre algo que ela já sabia, por assim dizer, valida a afirmação de Bakhtin a esse respeito. Segundo o autor, "seu herói [de Dostoiévski] sabe de tudo e tudo vê desde o começo. Daí serem tão comuns as declarações dos heróis (ou do narrador que fala dos heróis) depois da catástrofe, que mostram que eles já sabiam de tudo antecipadamente e o haviam previsto" ${ }^{100}$ Vejamos, abaixo, a impressão que a figura de Piotr causa em Niétotchka, logo no início de seu relato, da experiência que teve na casa de Aleksandra. Ela já prevê o seu caráter torpe

O marido de Aleksandra Mikháilovna causou-me, desde o primeiro momento, uma impressão sombria. Foi uma impressão que me surgiu na infância e que nunca mais se apagou. Ele era um homem alto, magro, e parecia esconder intencionalmente o olhar sob uns grandes óculos verdes. Seco e nada comunicativo, aparentava, mesmo a sós com a mulher, não encontrar assunto para conversa. Parecia pesar-lhe a presença de outras pessoas. (Dostoiévski:2009, p. 147)

Por parte da narradora, parece haver não só uma crescente ojeriza por Piotr como também um progressivo afastamento de Aleksandra.

\begin{abstract}
Impressionou-me sobremaneira a seguinte observação: parecia-me que ela, na medida em que eu me tornava mais adulta, ia se afastando mais de mim, de modo que a reserva que punha em seu trato comigo transformava-se até num sentimento de impaciência e despeito. Parecia mesmo haver momentos em que não me amava; era como se eu a atrapalhasse em algo. (Dostoiévski:2009, p. 162)
\end{abstract}

Essas sugestões de Niétotchka são confirmadas, posteriormente, pela boca de Piotr. Ou seja, gradativamente, a narradora observa, até pelas palavras de Aleksandra, que algo a incomoda

[...] Não é que eu possa suspeitar em ti algo mau - nunca! Eu não me perdoaria sequer um pensamento desses. Mas escuta: eu te recolhi menina, e agora estás com dezessete anos. (Dostoiévski:2009, p. 194)

É interessante notar o valor que dá Aleksandra à idade de Niétotchka, fazendo clara alusão ao fato de que a narradora já não é mais alguém sem malícia, isto é, não é mais uma criança, embora tente se convencer do contrário. Mas, nessas últimas lembranças da narradora, o que mais chama a 
atenção na casa de Aleksandra é uma crescente tensão entre ela e Piotr, que parece antecipar uma reviravolta na vida da heroína. A própria narradora se pergunta: “Que virá pela frente?”. A narrativa é interrompida em um momento de grande tensão. Vejamos a cena na qual Piotr encontra Niétotchka com a carta

\footnotetext{
- Basta! - disse, com uma voz enfraquecida pela pertubação. - você com certeza não quer que eu use a força; portanto, entregue-me voluntariamente a carta. (Dostoiévski:2009, p.198)
}

Se atentarmos para toda a situação que se desencadeia após Piotr ver a carta nas mãos de Niétotchka, partindo daí à suposições negativas sobre o caráter da menina, vislumbraremos cenas terríveis. Não somente pela cena de violência física que é insinuada por Piotr (que o trecho acima nos mostra), mas, sobretudo, pela violência ainda maior sugerida pela narradora

Escurecia. Estava sozinha, indefesa, diante daquele homem capaz de ofender uma mulher (...) (Dostoiévski:2009, p.200)

Vemos que a palavra "ofender" tem aí um duplo sentido, tanto no sentido de ofensa moral como também no de violência sexual, principalmente se notarmos como toda a situação vai tomando um rumo cada vez mais desfavorável para a narradora. Não somente palavras podem ofendê-la, como também ações podem dar conta disso. Tal é o fato que Piotr chega a sugerir usar de violência. A cena ganha outra dimensão, em que os sentimentos extrapolam a ponto de quase se concretizarem. Assim sendo, não é mais a força da palavra que entra aí em cena e sim a força física, que parece querer emergir no espaço da narrativa.

Outro ponto, que merece nossa atenção, é a maneira que Piotr se dirige a Niétotchka, a saber: dirige-se a ela de maneira repulsiva e sugestivamente lasciva.

\footnotetext{
- Não, é preciso acabar com isso! - disse ele finalmente, como se mudasse de intenção. - Confesso que cheguei a vacilar, por causa desse olhar - acrescentou com um sorriso estranho. - Mas, infelizmente, o caso é muito claro... E, se eu duvidei por um instante, isso demonstra apenas que, a todas as suas belas qualidades, devo acrescentar a capacidade de mentir admiravelmente, e, por isso, repito (...) (Dostoiévski:2009, p. 200)
}

A que "belas qualidades" de Niétotchka Piotr se referia? Às suas "belas qualidades" físicas? A questão é tal que, a própria Aleksandra desconfia da atitude do marido perante a menina de dezessete anos. E, quando as discussões chegam ao seu clímax entre os três, Piotr revela, diante da narradora, as preocupações de Aleksandra sobre o caso que a amargurava há algum tempo. 
[...] ainda ontem, por exemplo - você pensava, afirmava... mas eu não sei como dizê-lo; fico vermelho, com as suposições... você aludia ainda a não sei que outro sentimento capaz de me levar a essa severidade fora de propósito...

- Numa palavra, você tinha ciúme de mim por causa dela. (Dostoiévski:2009, p.202)

A situação toma tal dimensão que vemos, claramente, como a humilhação de todos os gêneros, sofrida por Niétotchka parece não ter fim. E ela vai se avolumando, vai ganhando corpo nos últimos momentos da narrativa

Era me penoso vê-la ao seu lado, em seus braços, à mesa conosco, em nossa casa, enfim... Por isso, e unicamente por isso, eu prestava atenção nela, vigiava-a, e foi dessa atenção que você se apercebeu, e, tomando como ponto inicial sabe Deus que suspeita, começou a bordar no seu bastidor sabe Deus o quê. Mas, agora, a situação está resolvida, está eliminada qualquer dúvida, e amanhã mesmo, senhora, amanhã, mesmo, não estará mais em minha casa! - concluiu ele, dirigindo-se a mim. (Dostoiévski:2009, p. 210)

Parece haver uma aglutinação de ofensas que vão se condensando, sugerindo, então, um desfecho não muito favorável para a protagonista. Será que a narradora passaria por algum "vale das tormentas", dada a sua sorte insinuada neste momento da narrativa, chegando ao ponto de ser expulsa da casa de sua benfeitora? Este parece ser um ponto da narrativa de muitas reticências.

Grossman, sobre essas cenas escandalosas, afirma que "são características da composição de Dostoiévski as cenas tumultuosas, em que participa muita gente, e que parecem abalar tôda a construção do romance: reuniões, brigas, escândalos, histerias, bofetadas, crises." ${ }^{101}$ E, de fato, parece surgir aí uma reviravolta no destino de Niétotchka.

Ainda sobre esses escândalos e catástrofes que vemos ao final da narrativa de Niétotchka Niezvânova, parecem-nos interessantes algumas questões levantadas por Bakhtin a esse respeito. A pesar de o autor analisar esses escândalos e catástrofes em uma perspectiva da sátira menipeia. Bakhtin argumenta que

essas cenas, que ocorrem habitualmente nos salões, são, evidentemente, bem mais complexas, policrômicas e completas que os contrastes carnavalescos, as marcantes mésalliances, as excentricidades e as essenciais coroações-destronamentos, mas têm uma essência interna análoga: rompem-se (ou pelo menos se debilitam por um instante) as 'cordas podres' [uma das falas do personagem Kliniêvitch de Bobók] da mentira oficial e individual e revelam-se as almas humanas, horríveis como no inferno ou, ao contrário, radiantes e puras. Por um instante as pessoas se veem fora das condições habituais de vida, como na praça pública carnavalesca ou no inferno, e então se revela outro sentido - mais autêntico - delas mesmas e das relações entre elas. ${ }^{102}$

101 Leonid Grossman. Dostoiévski Artista. Rio de Janeiro. Civilização Brasileira. 1967. P. 37.

102 Mikhail Bakhtin. Problemas da Poética de Dostoiévski. Forense Universitária. Rio de Janeiro, 2013. Pp. 166-167. 
Dadas essas considerações de Bakhtin além do que já foi exposto anteriormente, podemos pensar que a "corda podre" é rompida nesse momento na casa de Aleksandra Mikhailóvna. E, de fato, é tal o escândalo que faz emergir as verdadeiras relações entre as personagens. Ou seja, as más intenções de Piotr em relação à Niétotchka, a constatação de Piotr sobre a repulsa que a sua figura desperta na nossa narradora. E, finalmente, a revelação do ciúme que Aleksandra sente de Piotr por causa de Niétotchka. Há um descortinamento das verdades ocultadas de cada um até então.

Entretanto, também, observemos outro aspecto que reaparece na figura de Piotr, a saber: o seu discurso de ódio, nascido de seu preconceito pela menina. Isso, inevitavelmente, nos lança para o mesmo olhar da princesa, que a via de maneira igualmente preconceituosa, na medida em que, por mais que não expressasse dessa maneira mais direta, como o faz Piotr, o fazia por entre linhas, de maneira sutil. E isso foi um dos motivos que levou a separação de Niétotchka e Kátia, tirando a nossa narradora do seu convívio familiar. Portanto, Niétotchka é hostilizada nas duas casas que a abrigam por ter uma origem humilde.

É interessante observar como esse fato sempre emerge na narrativa, por mais que queiram ocultá-lo por meio de qualquer outra justificativa. Ocorre que ele é sempre revelado em momentos cruciais, como o que notamos acima. Sempre tentam dar a entender uma coisa quando na verdade é outra que os incomoda. No caso da princesa, o problema para ela tratava-se de que Niétotchka era responsável por "toda a transformação ocorrida com Kátia", o que ela via de maneira negativa. Piotr, por sua vez, acusa a narradora de não ter uma boa conduta, já que aceita cartas de amor de um amante, com quem ainda mantém uma relação. Isto é, nas suposições de Piotr, que quer fazer de Niétotchka uma menina desavergonhada e indigna.

Mas, se nos atentarmos para os verdadeiros fatos que são trazidos pela narradora, veremos que não se sustentam nenhum desses motivos que os instigam a ter tais pensamentos sobre ela. É como se eles (Piotr e a princesa) reiterassem que aquele não é o lugar da menina órfã, que ela não faz parte daquela sociedade. O convívio familiar surge, então, de maneira simbólica que alude a algo maior, ele reflete o convívio social dessa camada privilegiada, de nobres, que denotava, claramente, o lugar de cada um nessa sociedade. A questão da marginalização da narradora se confirma também aí, nessa hostilidade provinda dessas pessoas abastadas. O não-pertencimento de Niétotchka está colocado no desenvolvimento do enredo.

Sobre essa questão da marginalização de Niétotchka, que é também uma característica da personagem do subsolo, vejamos um ponto de vista de Bakhtin que parece pôr luz nesse aspecto que surge na narrativa. $\mathrm{O}$ autor argumenta que

o 'homem do subsolo' não só absorve todos os possíveis traços estáveis da sua imagem, tornandoos objeto de reflexão; nele esses traços desaparecem, não há definições sólidas, dele nada se tem a 
dizer, ele não figura como um homem inserido na vida; mas como sujeito da consciência e do sonho. ${ }^{103}$

Posto isto, vemos o quanto Niétotchka não estava, de fato, inserida naquela sociedade. A começar por ser uma criança órfã, que passa de casa em casa, e pelos indícios do que é narrado antes da narrativa se interromper abruptamente sugere, ela parece não encontrar nenhum lugar onde possa se achar em casa. As relações que a mesma mantém com outras crianças são relações hostis, em que se vislumbram muito mais um afastamento do que uma aproximação (com exceção, é claro, da sua breve relação com Kátia). Tudo isto, em si mesmo, já diz muito sobre a não-inserção na vida de Niétotchka.

Um ponto fundamental que Bakhtin aborda, pensando na elaboração da personagem do subsolo, e, por que não dizer, na elaboração da própria Niétotchka, é que tal personagem dostoievskiana é "sujeito da consciência e do sonho". O que vemos, ao longo de toda a narrativa, senão um sujeito (Niétotchka) da consciência e do sonho? Em vários momentos das suas reminiscências, a narradora encontra-se presa a pensamentos que a inquietam, da mesma forma que seus delírios e sonhos ocupam boa parte de sua vida. A sua existência real não ganha tantos contornos na narrativa como ganha a sua existência interior. Mais adiante será mais bem problematizada essa questão.

E para refletirmos ainda sobre esse ponto, Bakhtin afirma que

e é em vão que os próprios heróis sonham e desejam ardentemente personificar-se, incorporar-se ao tema normal da vida. A sede de personificação do 'sonhador' - gerado da ideia do 'homem do subsolo' - e do 'herói da família casual' é um dos importantes temas de Dostoiévski. ${ }^{104}$

Para elucidar o exposto, podemos pensar nos sonhos de Niétotchka com uma vida feliz ao lado do padrasto, o que não se concretiza. E, também, nos rumos que parece tomar a sua vida. Isto é, ela não consegue se inserir no cotidiano de nenhuma família que a adota. E, justamente por isso, é que são oportunas as considerações de Bakhtin, acerca do enredo das Memórias do Subsolo, para pensarmos a respeito do enredo de Niétotchka Niezvânova. O autor argumenta que

a vida do herói do subsolo é desprovida de qualquer espécie de enredo. A vida no enredo, na qual existem amigos, irmãos, pais, esposas, rivais, mulheres amadas, etc. e na qual ele poderia ser irmão, filho ou marido é por ele vivida apenas em sonho. Em sua vida real não existem essas categorias humanas reais. ${ }^{105}$

103 Idem. P. 57.

104 Idem. Pp. 115-116.

105 Idem. P. 294. 
Uma pergunta surge a partir daí: podemos chamar, verdadeiramente, de enredo tudo aquilo que Niétotchka expõe a nós, leitores?

No último capítulo desta pesquisa, traremos uma personagem para a discussão que foi retirada por Dostoiévski em 1860. A inserção no debate dessa personagem masculina faz-se necessária na medida em que, finalmente, esclarece o caráter de subsolo da nossa narradora. A inserção de tal personagem na análise explica, ainda, todas aquelas relações ambíguas que Niétotchka mantém com o outro. 


\title{
2.5 Niétotchka e Lária (um capítulo à parte)
}

O subsolo é muito amplo para se ter a última palavra sobre ele $\mathrm{e}^{106}$

Chama a atenção a retirada da personagem infantil Lária, em 1860, com quem Niétotchka parece encontrar o seu outro "eu".

Joseph Frank, em seu ensaio sobre Niétotchka Niezvânova, traz algumas considerações relevantes sobre o caráter dessa personagem feminina. Na concepção de Frank,

\begin{abstract}
o encontro com Lária é rápido e anuncia um desdobramento posterior: chamado por Niétotchka de “o futuro herói da minha história”, o menino logo desaparece, deixando no leitor a certeza de que voltará a falar dele depois. Entretanto, Dostoiévski eliminou essa cena quando decidiu republicar Niétotchka Niezvânova como um fragmento; mas é preciso recuperar a cena original, pois a importância de Lária não se limita ao seu futuro papel de "herói": ele também age como "imagem no espelho" de Niétotchka, e, mesmo nesse início, ajuda a compreender o significado da sua conturbada história psíquica. Ouvindo o relato de Lária sobre a vida dele, “cada vez mais eu me reconhecia", diz Niétotchka. "Foi Lária o escolhido para explicar toda a minha dor por intermédio da sua própria história”. Lária tem um enorme sentimento de culpa por causa de um comportamento cuja origem psicológica é muito parecida com a de Iefimov. Apesar de saber o quanto seus pais o amavam e o quanto a vida deles era difícil, o rapaz exagerava deliberadamente seus problemas e queixas infantis, porque a infelicidade dos pais lhe dava prazer. "Eu era tão tolo e idiota que, quando chegava da escola, contava de propósito que os outros garotos tinham-me batido", diz ele, "mas eu contava porque sabia que mamãe ia começar a chorar quando soubesse de tudo". Ele torturava os pais deliberadamente dessa maneira, "porque gostava tanto, quer dizer, eu gostava que mamãe chorasse por minha causa" (2: 443). Mas Lária decide mudar seu comportamento porque "tive pena da mamãe, Niétotchka" (2: 444). O destino, porém, o impede de pôr em prática sua decisão: na mesma noite, seu pai sofre um ataque cardíaco e sua mãe, poucos dias depois, segue o mesmo caminho do túmulo. ${ }^{107}$
\end{abstract}

Ainda segundo Frank,

a narrativa de Lária repercute profundamente em Niétotchka, porque esclarece seus próprios sentimentos e revela toda a sua ignomínia. Dostoiévski limita-se a sugerir esse processo de tomada de consciência sem descrever suas consequências. Em vez disso, uma Netotchka mais madura faz comentários genéricos sobre como as crianças podem ser corrompidas por um ambiente nocivo na infância e sobre como é fácil estimulá-las a desenvolver um ‘falso sentimentalismo' e muitas

106 Nota da pesquisadora.

107 Joseph Frank. Dostoiévski: As Sementes da Revolta, 1821-1849. São Paulo. Edusp, 2008. Pp. 449-450. 
'fantasias' que as levam a 'se pavonear e endeusar a si mesmas, a desenvolver o egoísmo, a egolatria e a sensualidade' $(2: 443) .{ }^{108}$

Dadas tais considerações de Joseph Frank, a respeito da obra analisada aqui, é importantíssimo darmos atenção a um dado que ele traz: a recuperação do personagem Lária, outra criança adotada pelo Príncipe K., com quem Niétotchka entra em contato.

Podemos pensar que Lária já é um protótipo do homem do subsolo. Frank afirma que Niétotchka Niezvânova é um esboço daquilo que mais tarde Dostoiévski realizará. ${ }^{109}$ Embora Dostoiévski tenha retirado da obra esse encontro (ou melhor, essa cena) de Niétotchka com Lária na sua republicação de 1860, o fato é que, em um primeiro momento, quando da elaboração de Niétotchka, Lária foi parte constitutiva nesse processo. Ao que tudo indica, o autor russo somente subtraiu essa cena entre ambas as crianças e renomeou os capítulos, mas não há indícios de que ele tenha reelaborado a personagem Niétotchka.

Sendo assim, de todos os elementos que a constituíam, como o momento histórico, precisamente a década de 40 do século XIX, o menino Lária foi outra peça fundamental para a elaboração de Niétotchka. É pelas fissuras que a própria narrativa vai nos dando que percebemos esse caráter de subsolo da Niétotchka, principalmente se nos atentarmos para a sua relação com o leitor, que é uma das marcas distintivas do homem do subsolo.

Pode-se pensar, também, que houve uma intencionalidade por parte de Dostoiévski ao retirar essa cena com Lária, de modo que pôde torná-lo o herói não deste romance (como a própria Niétotchka o chama), mas de uma futura novela: Memórias do Subsolo. Elaborando-o, a partir deste momento, de maneira mais aprofundada e orgânica. Não podemos perder de vista que o narrador das Memórias foi uma criança órfã, assim como Lária. A questão da orfandade parece ser significativa no entendimento geral da elaboração desse tipo de personagem, uma vez que tanto Lária e Niétotchka quanto o homem do subsolo carregam essa marca em suas infâncias, o que pode dar um indício de como se originou semelhante caráter de subsolo. Vejamos as próprias palavras do homem do subsolo:

- Sabe, Liza? Vou falar de mim! Se eu tivesse família, desde criança, não seria como sou agora. Penso nisto com frequência. De fato, por pior que possa ser a vida em família, tem-se pai e mãe e não gente estranha, inimiga. Pelo menos uma vez por ano, vão expressar o seu amor por você. Apesar de tudo, você sabe que está em casa. Eu cresci sem família; por isso, talvez tenha saído assim ... insensível. (Dostoiévski: 2000, p. 109)

108 Idem, p. 450.

109 Idem, pp. 461-462. 
Quem também atenta para este fato é Talita M. Cruz, em sua análise da personagem do subsolo, colocando que "de certo modo, Dostoiévski apresenta nesse segundo momento do livro a origem do homem torturado que fala à rouquidão no início da obra." ${ }^{110}$ É exatamente na segunda parte das Memórias do Subsolo que ficamos sabendo que o homem do subsolo também foi uma criança órfã e (principalmente) agia de maneira antinatural em relação às outras crianças, exatamente como Niétotchka e Lária.

Empurraram-me para aquela escola una parentes distantes, dos quais eu dependia e de quem, desde então, nunca mais ouvi qualquer notícia. Empurraram-me para lá, orfão, oprimido já pelas suas censuras, pensativo, silencioso, que espiava de modo estranho tudo ao redor. Os colegas receberam-me com zombarias malignas, desapiedadas, porque não me assemelhava a nenhum deles. (Dostoiévski: 2000, p. 81)

Mais uma vez, é importante pensarmos no ambiente hostil, por parte das próprias crianças, o qual se nota nessas infâncias narradas, o que, inclusive, chamou a atenção de Boris Schnaiderman. Niétotchka, em vários momentos de sua narrativa, põe relevo na péssima relação que tem com as crianças da sua vizinhança, exceto por sua breve relação com Kátia. Lária, por sua vez, sempre apanhava dos meninos na escola, evidenciando, assim, todo o seu desajuste social. E, finalmente, como vemos pelo trecho acima, o homem do subsolo já carrega desde a infância o trauma de não ser aceito, nem entre os seus iguais, isto é, nem entre as crianças.

Para pensarmos no que, aqui, está sendo colocado a respeito desse personagem que funciona, por assim dizer, como "imagem no espelho" de Niétotchka (utilizando aqui as palavras de J. Frank), observemos o seguinte trecho que foi extraído da obra.

\begin{abstract}
A criança é, por natureza, um déspota, e quem sabe se Lária já não havia descoberto a covarde satisfação de aceitar uma ofensa para logo depois descarregá-la numa pessoa inocente, assim como mais tarde conheci muitos egoístas que levavam seu egoísmo ao ponto da mais refinada e depravada sensualidade e descarregavam nos outros os insultos que haviam recebido a vida inteira; sem acalentar em suas almas ultrajadas o ódio pelo egoísmo, mas aferrando-se a uma só convicção: a de continuar sendo por princípio os mesmos egoístas, a fim de progredirem na vida e continuar atormentando os outros em nome de suas próprias desgraças, beneficiando-se do papel do espectador que se coloca à margem para ver como os outros vão se arranjar $(2: 443) .{ }^{111}$
\end{abstract}

No exame acima de Niétotchka sobre a personalidade de Lária, embora a narradora coloque numa forma de suposição, é notável como certas questões relevantes do caráter do homem do subsolo já se encontram problematizadas e moldadas no espírito do menino órfão. Quando

110 Talita Mochiute Cruz. "Notas sobre o anti-herói em Dostoiévski e em Beckett” In: Dostoiévski e Bergman: o niilismo da modernidade. Editora Intermeios, 2012. P. 98.

111 Joseph Frank. Dostoiévski: As Sementes da Revolta, 1821-1849. São Paulo. Edusp, 2008. P. 450. 
Niétotchka coloca que, talvez, Lária já "havia descoberto a covarde satisfação de aceitar uma ofensa para logo depois descarregá-la numa pessoa inocente", aqui, ela pode estar se referindo à relação de Lária com a sua mãe. Nas próprias palavras do menino: "eu era tão tolo e idiota que, quando chegava da escola, contava de propósito que os outros garotos tinham-me batido", e mais, "mas eu contava porque sabia que mamãe ia começar a chorar quando soubesse de tudo", "porque gostava tanto, quer dizer, eu gostava que mamãe chorasse por minha causa". Para entendermos melhor esse caráter contraditório do menino Lária, dessa confessada atitude em sentir prazer por atormentar os pais, notemos também essa particularidade no homem do subsolo,

Envergonhava me disso (e talvez me envergonhe ainda hoje); chegava a ponto de sentir certo prazerzinho secreto, anormal, ignobelzinho quando às vezes, em alguma terrível noite de Petersburgo, regressava ao meu cantinho e me punha a lembrar com esforço que, naquele dia, tornara a cometer uma ignomínia e que era impossível voltar atrás. Remordia-me então em segredo, dilacerava-me ... até que o amargor se transformasse, finalmente, em certa doçura vil, maldita e, depois, num prazer sério, decisivo! Sim, num prazer, num prazer! (Dostoiévski: 2000, pp. 19-20)

Heitor O'dwyer, em seu trabalho psicanalítico sobre algumas obras de Dostoiévski, traz uma questão fundamental acerca desse sentimento contraditório presente em algumas personagens dostoievskianas. Sentimento esse que o autor nomeia como o desconhecido. Segundo O’dwyer,

\begin{abstract}
o ponto de desconhecido fascina e valoriza as personagens: elas têm orgulho de sua singularidade radical. Esse ponto de desconhecido as repugna e acabrunha: projetadas em uma solidão abissal, elas experimentam dolorosamente o sentimento de serem excluídas da comunidade de seus contemporâneos. ${ }^{112}$
\end{abstract}

Vemos, claramente, pelo excerto acima da confissão do homem do subsolo (e também do menino Lária) um fascínio em causar dor no outro. Notamos que ambos têm orgulho de sua singularidade, apesar de isto causar-lhes repugnância.

Esta postura (ou impostura) de Lária nos remete, inevitavelmente, ao homem do subsolo. Por exemplo, lembremos da cena em que o homem do subsolo, depois de ter sido humilhado e ofendido por seus colegas, procura descarregar toda a sua frustração e humilhação em Lisa, a prostituta. $\mathrm{O}$ próprio homem do subsolo admite isto, vejamos:

[...] tinha que desabafar sobre alguém o meu despeito, tomar o que era meu; apareceu você, e eu descarreguei sobre você todo o meu rancor, zombei de você. Humilharam-me, e eu também queria humilhar; amassaram-me como um trapo, e eu também quis mostrar que podia mandar (...)

112 Heitor O'dwyer de Macedo. Os ensinamentos da loucura - A clínica de Dostoiévski: Memórias do Subsolo, Crime e Castigo, O duplo. Ed. Perspectiva. São Paulo, 2014. P. 6. 
A questão, portanto, não se limita apenas a descontar uma ofensa em uma pessoa inocente. Mais do que isso, há, confessadamente, um prazer em atormentar o outro, tanto da parte do menino Lária quanto do homem do subsolo.

Mas surge outra questão: Niétotchka fala do outro (Lária) ou de si mesma? Em que medida ela se utiliza da visão do outro para pôr luz sobre a sua real natureza espelhada no outro? São indagações que precisam ser colocadas, uma vez que, ao nos mostrar o outro, a narradora sutilmente mostra-nos a sua verdadeira face. Se voltarmos à sua relação com a mãe, notaremos como não somente Lária tiraniza a própria mãe como também Niétotchka o faz.

As lágrimas queriam jorrar-me dos olhos, mas eu endurecia-me e me continha. De certo modo, obstinava-me, evitando expressar perante ela o meu sentimento, embora eu própria sofresse com isso. Sim, aquilo não podia ser uma crueldade natural em mim. Não! O que me estragou foi o meu amor fantástico, excepcional, por meu pai. (Dostoiévski:2009, p.44)

Embora a narradora tente se justificar (aliás, durante boa parte da narrativa vemos esse movimento de justificação), fica claro como Niétotchka tiraniza a própria mãe. É como se dissesse: "eu endurecia-me e me continha" de propósito. Em vários momentos da narrativa do homem do subsolo vemos essa postura também, principalmente em relação à Liza. Em uma das cenas, na qual Liza vai até a casa do homem do subsolo, esse último afirma que,

[...] Para me vingar dela, jurei mentalmente não lhe dizer mais nenhuma palavra enquanto estivesse ali ... O nosso silêncio durava já uns cinco minutos. $\mathrm{O}$ chá estava sobre a mesa; não o tocamos: eu chegara a um estado tal que, de propósito, não queria começar a tomá-lo, a fim de tornar a situação dela ainda mais penosa, e ela sentia embaraço em começar. Por algumas vezes, olhou-me com uma perplexidade triste. Eu, obstinado, calava-me. O maior sofredor, sem dúvida, era eu próprio, pois percebia completamente toda a repulsiva baixeza da minha rancorosa estupidez e, ao mesmo tempo, não podia de modo algum conter-me. (Dostoiévski: 2000, p. 136)

E o que chama a atenção do leitor é a consciência de ambas as crianças (Niétotchka e Lária) e do homem do subsolo de sua ignomínia. Quem observa de maneira perspicaz esse comportamento do subsolo é Boris Schnaiderman, afirmando que "essa 'consciência cindida' é captada em sua maior miséria em Memórias do Subsolo, e o trágico da situação ali provém sobretudo do fato de que a personagem ignóbil está perfeitamente cônscia de sua ignomínia." ${ }^{113}$ Quem faz uma leitura nesse sentido é Perrone-Moisés, em seu trabalho comparativo entre Fernando Pessoa e o homem do subsolo. Segundo a autora,

113 Boris Schnaiderman. "Dostoiévski: a ficção como pensamento”. In: ArtePensamento. Companhia das Letras. São Paulo, 1994. P. 243. 
em Pessoa, como no 'homem do subsolo', essa confissão [da consciência de sua vileza] não tem pretensão de se reverter em apologia de um herói do mal; também não tem o sentido purgatório de um confiteor cristão; trata-se apenas do reconhecimento lúcido de uma vileza reles, sem nenhuma exultação de tipo moral, apenas aquela volúpia da desqualificação a que se referia Pessoa [... $]^{114}$

Ainda sobre a consciência dessa personagem que habita o subsolo, Perrone- Moisés faz a seguinte observação:

Seria mera coincidência de temperamentos, entre a personagem dostoievskiana e as 'personas' pessoanas? Evidentemente não. Essa consciência é a do homem moderno, para quem os valores morais e estéticos do passado, confrontados com a mediocridade e a brutalidade da vida cotidiana nas grandes cidades (peters) burguesas, esgarçam-se como diáfanas fantasias de outros tempos. ${ }^{115}$

A autora, quando localiza nessa personagem tal consciência da vileza como sendo fruto da Modernidade, o faz com razão, uma vez que o homem moderno é, por excelência, um homem cindido. O crítico Joseph Frank, em certa medida, corrobora essa ideia, apontando a ignomínia de Niétotchka ${ }^{116}$, legitimando, em boa medida, a hipótese que estamos levantando.

Outro autor que corrobora, de certa forma, a ideia dessa consciência da maldade da personagem do subsolo, a que Schnaiderman chama a atenção, é Pareyson. Segundo o crítico italiano,

as Memórias do Subsolo não dão lugar ao culto de verdades nobres e generosas, sublimes e ideais e à edificação do esplêndido 'palácio de cristal' do futuro, mas impõem a procura da verdade sem véus, da sinceridade absoluta, da admissão franca e até cruel da realidade do mal e da mesquinhez dos homens, da impossibilidade de fechar os olhos diante da pecaminosidade e do sofrimento do homem. ${ }^{117}$

Como já foi apontado acima, Niétotchka em alguns momentos da narrativa, expõe de maneira franca a sua maldade contra a mãe, independente do movimento de justificação que vemos no decorrer do seu discurso.

Pensando, aqui, nessa ignomínia das personagens subsolianas, por assim dizer, são interessantes e oportunas algumas considerações de Nicolai Mikhailóvski sobre o narrador das

\footnotetext{
114 Leyla Perrone-Moisés. “A multidão, o subsolo e a mansarda”. In: Fernando Pessoa, aquém do eu, além do outro. São Paulo. Martins Fontes, 2001. P. 67.

115 Idem, p. 68.

116 Joseph Frank. Dostoiévski: As Sementes da Revolta, 1821-1849. São Paulo. Edusp, 2008. Ver p.450.

117 Luigi Pareyson. Dostoiévski Filosofia, Romance e Experiência Religiosa. São Paulo. Edusp, 2012. P. 25.
} 
Memórias do Subsolo. Embora Mikhailóvski se oriente para uma leitura propriamente da maldade presente na personagem do subsolo, ainda assim, é pertinente um fator para o qual ele chama a atenção, uma vez que põe mais luz para entendermos tal característica dessa personagem. Segundo o crítico russo,

talvez o mais interessante em Memórias do Subsolo seja essa falta de motivos na exasperação do homem do subsolo contra Liza. Em geral não se encontra motivo algum para sua exasperação [...] É como se toda a sua torpeza se explicasse por uma autogênese, ou até mesmo não exigisse explicação alguma. [...] muito mais interessante é o fato de o homem do subsolo começar a torturar Liza por absolutamente nenhuma razão, simplesmente por ela estar à mão [...] O herói tortura porque gosta, porque lhe agrada torturar. ${ }^{118}$

Niétotchka, durante toda a narrativa tenta justificar a sua maldade contra a mãe, mas sem muito êxito. Por mais que a narradora vai se justificando ao longo das suas memórias, esse parece ser um movimento de justificação que não encontra apoio naquilo que é narrado. O mesmo podemos dizer sobre o menino Lária e o narrador das Memórias. Nesse sentido, pensando nessa autojustificação da narradora, nessa desarticulação do seu discurso com os fatos narrados, podemos entendê-la como um recurso de evasiva. Quem chama a atenção para esse aspecto é Beth Brait, em seu estudo sobre a abordagem de Bakhtin nas Memórias. A autora ressalta que,

o modelo artístico da novela, inicialmente definido como confissão, assume outra configuração ao ser observado a partir da articulação do discurso com evasivas. Como revela Bakhtin, 'A evasiva é o recurso usado pelo herói para reservar-se a possibilidade de mudar o sentido último e definitivo do seu discurso', deixando em aberto as possibilidades de conclusão de sua imagem. Nesse sentido, tudo aquilo que enuncia 'é apenas a penúltima palavra e coloca depois de si somente um ponto condicional, não um ponto final'. ${ }^{119}$

Brait observa ainda o seguinte:

a falta da última palavra (ou mesmo do ponto final) que encerre o continuum das provocações polêmicas oferece uma singular construção do inacabamento que o sabemos fundamental ao modelo artístico criado por Dostoiévski. Trata-se do processo de ficcionalização da própria conclusão, que deixa em aberto o raciocínio. Com isso, no entender de Bakhtin, 'A evasiva cria um tipo especial de última palavra fictícia sobre si mesma, mas com tom aberto, que fita

118 Nicolai Mikhailóvski. “Um talento cruel”. In: Antologia do Pensamento Crítico Russo (1802-1901). Editora 34. São Paulo, 2013. Pp. 437-438.

119 Beth Brait. "O encontro privilegiado entre Bakhtin e Dostoiévski num subsolo / The gifted underground's meeting between Bakhtin and Dostoevsky”. In: Revista Bakhtiniana. São Paulo, 2011. Pp. 39-40. 
obsessivamente os olhos do outro e exige do outro um desmentido sincero. [...] A evasiva torna instável todas as autodefinições das personagens, o discurso destas não se fixa em seu sentido mas a cada instante, à semelhança de um camaleão, está pronto para mudar a cor e seu último sentido'. Como consequência, o discurso com evasivas preserva a atitude ambígua do herói e de sua visão destorcida, até mesmo para si, como se pode concluir a partir das palavras de Bakhtin: 'O herói não sabe de quem é a opinião, de quem é a afirmação, enfim, seu juízo definitivo: não sabe se é a sua própria opinião, arrependida e condenatória, ou, Idem, ao contrário, a opinião do outro por ele desejada e forçada, que o aceita e o absolve'. ${ }^{120}$

Sobre as evasivas presentes no discurso do homem do subsolo, Brait também afirma que

o silêncio que ocupa o campo do não-dito não pode jamais ser ignorado. Como excedente de um campo de visualidade, o não-dito forma o campo da extraposição. Trata-se de um discurso igualmente in absentia do qual também não se sabe qual será a última palavra." ${ }^{121}$

Brait traz para sua análise as reflexões de Gary Saul \& Caryl Emerson, sobre como eles entendem esse recurso da evasiva. Para os críticos, "o discurso com evasivas aparece como o ato que antecede e prepara o caminho para a emergência do próprio discurso. ${ }^{122}$

Brait ainda enfatiza que

retomando a construção da novela Memórias do Subsolo, de Dostoiévski, em suas partes, interrogamos em que medida a segunda parte da narrativa do herói do subsolo sobre o seu passado - marcado com os conflitos com seu superior, com seus colegas e com Lisa - não representaria a preparação para o discurso que seria pronunciado vinte anos depois. É na segunda parte da novela - quando ele é jovem e, portanto, não manifesta nenhuma doença que pudesse ser responsável pelo seu mau humor, quando nem mesmo o fígado reage aos excessos da bebida, - que ele se afirma e se reconhece em sua maldade. Não sem motivo, quando chega ao final da narrativa, apenas reconstitui os termos do início da novela. ${ }^{123}$

Articulando as considerações de Brait (e dos teóricos com os quais ela dialoga) com a maneira como Niétotchka organiza seu discurso, podemos pensar que, ao jogar para o leitor a questão da sua maldade contra a mãe, além de ela não fechar a questão, com a sua rasa explicação, a amplia, no sentido de gerar cada vez mais indagações sobre o que está por trás do seu discurso. Niétotchka

120 Idem, p. 40.

121 Idem. Ibidem.

122 Idem, pp. 40-41.

123 Idem, p. 41. 
articula o seu discurso produzido com as questões que, porventura, possam surgir do leitor. E, sendo assim, escapa à sua própria explicação, que, consequentemente, cria aí também um silêncio, que como bem observa Mikhailóvski, cria essa falta de motivos para essa exasperação. Vejamos uma de suas justificativas:

[...] muitas vezes eu me atormentava até sentir dor, pelo fato de ser tão inabalavelmente fria com minha própria mãe; havia momentos em que, olhando para ela, sentia-me dilacerada de angústia e compaixão. Em face da contínua inimizade entre ambos, eu não podia permanecer indiferente, tinha que tomar o partido de um deles, e tomei então o daquele homem quase louco, apenas porque me parecia tão lastimável, tão humilhado, e porque, desde o início, me impressionara de modo tão extraordinário a imaginação. Mas - quem poderá julgar? - é possível que eu me afeiçoasse assim a ele, justamente, por ser tão estranho mesmo em seu aspecto exterior, e não fosse tão sério e taciturno como minha mãe; por ser quase louco; porque, com frequência, tinha algo de bufão e certos modos infantis; e, finalmente, porque eu o temia menos e até o respeitava menos que a minha mãe. De certo modo, assemelhava-se mais a mim. (Dostoiévski:2009, p. 58)

É interessante observar a sobreposição de supostos motivos para seu desafeto com a mãe. A narradora vai elencando possíveis razões para sua frieza em relação a ela. Mas, como foi dito, anteriormente, sua justificação parece não encontrar apoio na sua própria narração. Pensemos, por exemplo, na colocação de Niétotchka sobre a sua mãe ser tão séria e taciturna. Ora, em alguns momentos de sua narrativa a figura da mãe, quando raramente aparece nas reminiscências da narradora, sempre surge como uma mulher oprimida, principalmente pelo marido, quem era, por sua vez, idolatrado pela filha. Não podemos nos esquecer do fato de ser a mãe de Niétotchka aquela que trabalhava para garantir o sustento da família. O próprio Iefimov chama a atenção da filha para esse aspecto, da mãe dela ser a única que provém a família.

Esses dados da mãe de Niétotchka surgem na narrativa, de tal modo que fica insustentável a argumentação da narradora, segundo a qual, a sua mãe era mais séria e taciturna do que o pai. $\mathrm{O}$ fato é que sua mãe era, sim, oprimida não só pelo padrasto como pelas circunstâncias daquele período, sem contar o fato de a mesma sentir a rejeição da própria filha. Niétotchka quer nos fazer parecer ser apenas o caráter da mãe, que surge de maneira negativa, como o determinante para o seu mal-estar diante dela.

Mas a sua mãe é, na verdade, apenas uma mulher oprimida que a narradora tenta deformar ao mostrar outra coisa. Encobrindo, desse modo, o verdadeiro motivo da sua exasperação. Ou melhor, Niétotchka tenta encobrir aquilo que ela mesma não consegue explicar e joga para o leitor. Cria-se, assim, um vazio no seu discurso, que não consegue minimamente se ancorar em nenhum dado objetivo, como também dá margem para a interpretação de Mikhailóvski sobre essa personagem do subsolo se exasperar por motivo algum.

E, voltando às considerações de $\mathrm{O}^{\prime}$ dwyer, o autor afirma que 
Dostoiévski apresenta suas personagens às voltas com uma descoberta escandalosa que elas não conseguem designar, mas cujos efeitos aceitam corajosamente. Como Dostoiévski compartilha com elas essa experiência do inominável, o leitor, por sua vez, é convidado a participar de uma busca ancorada na palavra- as personagens de Dostoiévski falam o tempo todo-, busca vertiginosa em torno de um ponto desconhecido que, como sabemos hoje, se chama inconsciente. ${ }^{124}$

Quem corrobora, de certa maneira, a ideia do inominável nas obras de Dostoiévski é Ekaterina V. Américo. A autora cita Lotman quem argumenta que "as palavras não nomeiam os objetos e as ideias, mas fazem espécie de alusões a eles" ${ }^{125}$. A autora acredita que

de fato, ao lermos Dostoiévski sempre nos deparamos com as falas dos personagens que não conseguem se expressar, gaguejam, repetem as palavras. Além disso, temos a sensação de que 'algo', talvez o mais importante, deixou de ser dito. ${ }^{126}$

Sobre esse "inominável" a que se refere O'dwyer, ou mesmo sobre esse "algo que deixou de ser dito", na concepção de Ekaterina Américo, observemos que, nesse movimento de justificação da maldade contra a mãe, Niétotchka parece deixar escapar, por assim dizer, aquilo que fica, ou melhor, aquilo que sobra da sua personalidade do subsolo. Quem atenta para este fato é Vladímir Zakhárov. Segundo o autor,

o 'subsolo' é uma metáfora e Dostoiévski deu a ela um significado simbólico. A palavra tornou-se um sinal de estado especial, porém típico, na opinião do escritor. Assim é chamado aquilo que 'sobra' da personalidade que o Homem se cala. Ele permanece calado por vinte anos, como um adepto dos paradoxos; por noventa anos, como o grande inquisidor. ${ }^{127}$

De fato, passado tantos anos (tudo leva a crer que decorreram muitos anos), ela se cala diante do fato de sua maldade contra a mãe. E o que reforça aquilo que não é dito, é que a história da mãe raramente aparece ao longo da narrativa. Mas o que causa um nó a mais na cabeça do leitor é essa contradição em que a figura da mãe pouco aparece nas reminiscências ao mesmo tempo em que se avolumam as suas justificativas para explicar a maldade contra a mãe.

Vale observar que o presente estudo visa demonstrar como há um movimento de justificação

124 Heitor O'dwyer. Os ensinamentos da loucura. A clínica de Dostoiévski: Memórias do Subsolo, Crime e Castigo, O Duplo. Editora Perspectiva. São Paulo, 2014. Pp. 5-6.

125 Ekaterina Vólkova Américo. Fiódor Dostoiévski pelo viés lotmaniano. Revista Rus. P.43.

126 Idem. Ibidem.

127 Vladímir Zakhárov. Dostoiévski, um escritor do século XXI. Revista Rus, v.6, n.6. 2015. P. 7. 
que não se justifica. Quanto à difícil tarefa de solucionar a questão, fica em suspenso, dada a complexidade daquilo que está por trás de tal movimento, que tentamos minimamente problematizar e jogar luz, valendo-nos de algumas observações pertinentes de alguns autores, tais como os presentes ao longo da pesquisa.

Pensando também na ironia presente na narrativa (e principalmente nesse tipo de personagem do subsolo), e que, obviamente, é muito mais ampliada em Memórias do Subsolo, são interessantes as observações de Vassoler a esse respeito. O autor argumenta que "a ironia do subsolo não é apenas um matiz que colore a narrativa de vez em quando. A ironia estrutura a narrativa e a faz mover-se sobre e contra si mesma, como que a forjar os alicerces do subsolo." 128 Posto isso, é válido nos voltarmos para tal ironia que faz a narrativa "mover-se sobre e contra si mesma" a fim de entendermos o próprio movimento de justificação a que se incube Niétotchka.

Em dado momento, a narradora é irônica ao falar de um "acaso" em que seu padrasto (Iefimov) conversa com a mãe dela. A ironia surge aí causando um estranhamento, uma vez que isso vai contra o movimento de justificação da maldade dela contra a própria mãe, que é desenvolvido durante a narrativa. Ou seja, Niétotchka ironiza a relação praticamente nula de Iefimov com a mãe dela, ao mesmo tempo em que diz que isso lhe causa dor.

Nesse momento, percebemos o choque que se dá entre aquilo que a narradora diz (querendo mostrar empatia pela dor de sua mãe) e as intenções por trás do seu discurso, mostradas aí pela ironia. Niétotchka ironiza aquilo que deveria causar nela indignação, indo, deste modo, contra o seu próprio movimento de justificação. É, então, que vemos a total falta de empatia da narradora por sua mãe. Podemos pensar em um movimento de falso compadecimento.

É interessante notar que se tem uma impressão de não haver idéia alguma que se externalize em Niétotchka, mas a maldade dela contra a mãe, ou melhor, esse movimento de justificação de sua maldade pode ser entendido como a grande ideia presente nessa obra. Percebe-se um fervilhar de ideias em sua mente, mas isso escapa e toma corpo no seu discurso. E, nesse sentido, vai ao encontro de uma das ideias presentes em Memórias do Subsolo, a saber, a ideia de o porquê da maldade humana, ou seja, o porquê da maldade contra o outro.

Voltando à questão do egoísmo, que é tão bem problematizada pelo narrador de as Memórias do Subsolo, poderíamos pensar que, dada a publicação em 1860 da obra, esse tema deveria estar inquietando Dostoiévski naquele exato momento histórico. Entretanto, Frank traz um dado importante sobre essa questão do egoísmo, a qual põe luz em uma série de fatos que verificamos em Niétotchka Niezvânova, publicada na década de 1840. O autor argumenta que

128Flávio R. Vassoler. Dostoiévski e a Dialética: Fetichismo da Forma, Utopia como Conteúdo. Tese. 2015.

Pp. 63-64. 
Dostoiévski, como iremos ver, transpôs, para esse texto [Memórias do Subsolo] tudo o que aprendera na prisão sobre a necessidade inerradicável da personalidade humana de possuir um senso de sua própria autonomia; e mesmo antes de ser transportada para a consciência do homem do subterrâneo [...] De fato, Dostoiévski tomou consciência do poder do egoísmo muito antes dos quatro amargos anos que passou no presídio. Era uma verdade sobre a natureza humana da qual se convencera nos anos de 1840, quando a publicação da obra de Max Stirner, O Ego e o Que lhe é Próprio (uma defesa apaixonada do direito do ego individual de satisfazer suas próprias necessidades antes de tudo o mais e de ter precedência sobre todas as regras abstratas e gerais da lei e da moralidade) trouxera à baila a questão do egoísmo. [...] O livro fora muito discutido nos círculos socioculturais em que andava Dostoiévski. ${ }^{129}$

Dada essa perspicaz observação de Frank, podemos pensar que já em Niétotchka Niezvânova encontra-se, na forma de um esboço, essa questão do egoísmo. Isso pode ser observado principalmente na elaboração da personagem Lária, que, como bem pontua Frank, funciona na narrativa como imagem no espelho de Niétotchka.

Em contraste à falta de empatia dela pela própria mãe, vislumbramos outra relação que a narradora mantém com o padrasto. Salvas as ambiguidades que se verificam também nessa relação com Iefimov, as quais já foram mencionadas no início desse trabalho. Mas nos atentemos para essa outra relação da narradora.

Já em Niétotchka Niezvânova aparece o que podemos chamar de um procedimento artístico de Dostoiévski, que mais tarde se desenvolverá em seus outros romances. Nessa relação de Niétotchka com Iefimov há uma espécie de "salvação frustrada". Isto é, esse ser do subsolo parece ser um salvador frustrado, uma vez que se constitui como mero observador da desolação humana, embora até o último momento não meça esforços para a realização de seu desejo de salvação. É exemplar o último contato de Niétotchka com seu padrasto, até o último momento ela não o deixa, chegando a hesitar em ficar ao lado da cabeceira de morte de sua mãe ou fugir com Iefimov.

[...] Sim, Niétotchka, isso não está certo; temos que ir para junto de mamãe; ela está com frio lá! Vai para junto dela, Niétotchka, vai; lá não está escuro, lá existe uma vela; não tenhas medo, chama alguém para junto dela, e, depois, volta para perto de mim. Vai sozinha; eu te esperarei aqui... não irei embora.

Pus-me imediatamente a caminho, mas, apenas pisei o passeio da rua, senti uma pontada no coração... Voltei-me e vi que ele já descera a encosta do outro lado e que estava fugindo, deixando-me sozinha, abandonando-me numa hora daquelas! Gritei com todas as forças e, terrivelmente assustada, pus-me a correr, procurando alcançá-lo. Extinguia-se em mim o alento, minhas pernas dobravam-se. Uma sensação de tortura me dilacerava: tinha pena dele, e o coração doía-me ao imaginar como ele corria, sem capote, sem chapéu, fugindo de mim, a sua filha querida... Queria alcançá-lo unicamente para beijá-lo com força mais uma vez, para dizer-lhe que não me temesse, convencê-lo disso, tranquilizá-lo, assegurando-lhe que, se não quisesse, não correria atrás dele e iria sozinha para junto de minha mãe... Alcançando-a e dobrando igualmente a esquina para segui-lo, tornei a vê-lo... Nesse 
momento, perdi as forças: pus-me a chorar, a gritar.

- Papaizinho! Papaizinho! - gritei pela última vez; mas, de repente, escorreguei sobre o passeio e caí junto ao portão de uma casa. Senti que o sangue me corria por todo o rosto. Um instante depois, perdi os sentidos..." (Dostoiévski:2009, pp. 80-81)

Embora aja, por vezes, com certa arrogância, com certo ar de superioridade, no relato de suas lembranças, típico das criaturas do subsolo, Niétotchka tem, contudo, compaixão por Iefímov. Ele faz parte de um grupo de excluídos da sociedade, os alcoólatras, que chegam a esse ponto motivados, muitas vezes, por um Estado opressor que inviabiliza qualquer forma de liberdade, seja ela material ou mesmo espiritual. Nesse sentido, Grossman, aponta para esta questão e afirma que,

\begin{abstract}
Dostoiévski gostava de construir obras literárias baseadas em fatos verdadeiros e concretos da realidade cotidiana, embora com a sua ampliação no sentido das vastas apreciações filosóficas e das conclusões políticas. Tornou-se característico em sua obra o emprego de dados do jornalismo de seu tempo, sob o signo da elaboração dos grandes problemas éticos e sociais. As ideias fundamentais de seus romances são frequentemente argumentadas com notícias do dia. Dostoiévski completava amplamente esse método fundamental de seu trabalho literário com uma reserva riquíssima de observações da vida na Rússia e na Europa e uma vasta leitura sobre todas as questões que o preocupavam. ${ }^{130}$
\end{abstract}

Ainda de acordo com Grossman, Dostoiévski

acompanhava com atenção as mais recentes monografias históricas e políticas, a imprensa cotidiana e mensal, as novas concepções na ciência, as últimas realizações na literatura. A imagem de Marmeladov faz eco a uma série de artigos da revista de Dostoiévski, sobre o tema atual do alcoolismo (em $1^{\circ}$ de janeiro de 1863 , foi introduzido um sistema de imposto de consumo sobre as bebidas alcoólicas, em substituição à tradicional cessão de direitos sobre a sua venda). Sobre o fundo desses numerosos artigos, em que se mostrava a relação do alcoolismo com a prostituição, a tuberculose, o desemprego, a mendicância, a infância desamparada, com a extinção física de famílias inteiras, surgem em toda a nitidez as linhas mais importantes da história dos Marmeladov. ${ }^{131}$

Iefimov era um homem esmagado pelo seu meio: pensemos, aqui, numa visão mais ampla, típica de Dostoiévski, e não fechada nas prescrições dos ensaios fisiológicos em voga. A própria maneira de a narradora estruturar as suas recordações de criança mostra, de certa forma, (pensando aqui especificamente nos extratos sociais da época, uma vez que o personagem Iefimov se move também motivado por outras questões mais complexas) como Niétotchka sabia o que fez com que 130 Leonid Grossman. Dostoiévski Artista. Rio de Janeiro. Civilização Brasileira, 1967. P. 69. 131 Idem. Pp. 69-70. 
seu padrasto saísse como um alcoólatra e um sonhador. Certos aspectos de sua vida são minuciosamente colocados para mostrar o que ali existia, evidenciando, assim, o desmascaramento social daquela Rússia do XIX. Como exemplo, podemos pensar na repercussão gerada pela posse de Iefimov do violino de seu amigo italiano.

Através deste pequeno incidente, Dostoiévski faz emergir toda a problemática da servidão russa, nos seus aspectos mais contraditórios. Tais como, o teatro dos servos, que na obra em questão trata-se das orquestras particulares desses senhores de terra. O que, na realidade, é parte de um mesmo processo de exploração, que falsamente era vendido como um processo de inclusão desses servos. A arte era colocada, então, como a grande niveladora dos conflitos sociais.

Quando Iefimov é intimado a vender o violino do italiano, que havia lhe deixado como herança, percebe-se em sua própria fala uma ironia, uma vez que até mesmo lhe fazem uma oferta (três mil rublos). O conde e o proprietário fazem uma oferta, mas o que está implícito é exatamente a relação da servidão russa. Esta oferta é feita como um modo de encobrir a verdadeira relação de posse entre servos e proprietários. A oferta entra aí como mero instrumento de poder, não é uma questão de aceitar ou não, mas de que ela tem de ser aceita. Não é uma opção, como quer fazer parecer a fala dos senhores, mas uma intimação.

- Por que você não quer vender o violino? Não precisa dele. Estão oferecendo três mil rublos pelo instrumento, é o preço justo e você não tem razão em pensar que poderão pagar mais. O conde não pretende, de modo algum, enganá-lo.

Iefimov respondeu que, por vontade própria, não iria procurar o conde, mas que, se o enviassem lá, cumpriria a vontade de seu senhor; não venderia o violino ao conde, mas, se o tomassem à força, iria submeter-se, também neste caso, à vontade de seu amo.

- Está bem! - respondeu o proprietário. - Vou informar o conde de que não lhe vende o violino pela simples razão de que não quer vendê-lo, visto que fazê-lo ou não só depende de você, entende? Mas, cá entre nós, para que precisa do violino? Seu instrumento é o clarinete; aliás, você é um péssimo clarinetista. Ceda-me o violino e lhe darei três mil.

Iefimov sorriu.

- Não, meu senhor, eu não lhe vou vender o violino - respondeu. - Está claro que o senhor tem todos os direitos (...) (Dostoiévski:2009, p. 11)

Dostoiévski não somente expõe tais relações dos proprietários com as suas orquestras, como também faz uma severa crítica, por meio dos discursos ambíguos que surgem nessas situações. E, sobretudo, utiliza-se do personagem Iefimov (padrasto de Niétotchka) para atacar e ironizar essas relações entre esses proprietários de orquestras e os seus músicos, entre os quais muitos eram servos. Vejamos mais alguns trechos: 


\begin{abstract}
- Mas estou acaso coagindo? Porventura estou procurando obrigá-lo a isso?! - pôs-se a gritar o proprietário, fora de si, tanto mais que a cena se passava na presença do músico do conde, que podia tirar daí uma conclusão muito desfavorável sobre a sorte de todos os músicos de sua orquestra. - Vá embora, ingrato! E que eu não te veja mais! Sem mim, onde você acabaria com o seu clarinete, que mal sabe tocar? A meu serviço está alimentado, vestido, recebe ordenado; vive como um nobre, é um artista, mas não quer compreender nem apreciar nada disso. [...] o proprietário recebeu uma carta do francês, em que este recusava com altivez o seu convite, acrescentando, naturalmente com rodeios, que, dali por diante, seria extremamente cauteloso nas suas relações com os senhores donos de orquestras particulares; que era antiestético ver um talento verdadeiro à merce de um homem incapaz de apreciar-lhe o justo valor e que, finalmente, o exemplo de Iefimov, artista autêntico e o melhor violinista que ele tivera oportunidade de conhecer na Rússia, constituía prova evidente da veracidade de suas palavras.

Disse, ainda, que Iefimov não era servo, gozava de plena liberdade e poderia tê-lo abandonado a qualquer momento, se realmente sofresse coação.

Tudo isso deixou o conde extremamente irritado, levando-o simplesmente a chamar meu padrasto de patife e caluniador e a dizer que ele merecia o castigo mais vergonhoso. (Dostoiévski: 2009, pp. $11,13 \mathrm{e} 15)$
\end{abstract}

Se atentarmos para os dois últimos excertos da obra acima, verificaremos como o estatuto da servidão é, o tempo todo, ironizado por Dostoiévski na própria tessitura da obra. A palavra "castigo" sempre esteve historicamente ligada ao estatuto da escravidão, que, no caso russo, é a servidão. É interessante notar, além disso, que na obra Niétotchka Niezvânova não surge nenhuma personagem "serva" que trabalhe nessas orquestras particulares. Todavia, pelas discussões que vemos na narrativa, percebe-se o tratamento dado não somente aos servos dessas orquestras como também aos músicos de origem humilde. Uma das contradições que surge na narrativa, pela boca do conde, é essa referência ao "castigo mais vergonhoso" que Iefimov deveria receber, mesmo o conde tendo dito antes que Iefimov não era servo.

É sabido que esses "castigos mais vergonhosos" eram desfechados contra os servos (mesmo contra aqueles que participavam dos teatros e de outros eventos culturais). Portanto, quando o conde diz que Iefimov deveria recebê-los, mesmo não se tratando de um servo, nos dá uma boa medida do que de fato eram muitas daquelas relações entre os proprietários financiadores dos espetáculos culturais e os músicos de suas orquestras.

Niétotchka vê e sente todo esse drama vivido pelo padrasto e se compadece, buscando, de todas as formas possíveis, inclusive mentindo para a própria mãe, aliviar esse peso que é a existência de Iefímov. E é isso que lhe move até o último instante na sua relação complexa com o padrasto. Há, de fato, uma complexidade ainda maior nessa relação dos dois. Pensemos na cena final entre ambos, que foi reproduzida mais acima. Nela, o desespero de Niétotchka é tão grande e avassalador, como podemos notar pela própria descrição dos fatos, que mostra o pressentimento da narradora sobre aquilo que se dará: a ruptura na sua relação com Iefímov e, principalmente, a sua perdição moral. O que resultará na morte dele e na frustração de Niétotchka, quem almejava uma salvação possível.

Tal procedimento artístico na elaboração dessa personagem subsoliana, se verificará, mais 
tarde, também na relação do homem do subsolo com Lisa, a prostituta. Por mais que o homem do subsolo tente se convencer (e de nos convencer, leitores) de que ele precisava descontar em alguém a humilhação sofrida anteriormente por parte de seus colegas e a primeira pessoa que lhe aparece é Lisa, o fato é que, desde o primeiro contato com Lisa, ele sente a necessidade de salvá-la. Todo aquele sermão do homem do subsolo é muito verdadeiro (se lermos o que está nas entrelinhas). Isso porque ele se empenha, até o fim, em salvá-la daquele seu destino. Não são palavras jogadas ao vento e sim uma tentativa desesperada de alcançar seus objetivos. É interessante observar um de seus pensamentos quando da espera da visita de Lisa em sua casa.

Estou salvando Lisa, justamente pelo fato de que ela vem a minha casa e eu lhe falo... Faço-a progredir, cuido da sua instrução. A seguir, percebo que ela me ama, que me ama apaixonadamente. Finjo não compreender (não sei bem para que este fingimento; provavelmente, apenas porque fica mais bonito). Finalmente, toda envergonhada, bela, trêmula, aos soluços, atirase a meus pés e me diz que sou seu salvador e que ela me ama acima de tudo no mundo (...) (Dostoiévski: 2000, p. 127)

Há nesse tipo de personagem uma necessidade de salvar o próximo, principalmente se este estiver em uma situação degradante, totalmente à margem da sociedade. Lisa representa a prostituição, cujas mulheres não estão somente à margem, mas representam para a sociedade uma espécie de câncer, de mal que precisa ser expurgado desta mesma sociedade. Podemos encontrar ainda tal procedimento de Dostoiévski na relação de Raskólnikov com Marmeládov, uma vez que, não somente trava conversa com o pobre homem, como também se envolve com a sua triste história familiar. Buscando, com isso, salvá-lo moralmente. Em tal procedimento artístico de Dostoiévski de "salvador frustrado", podemos pensar na relação direta que o autor faz com a questão do cristianismo ortodoxo russo. Quem corrobora essa ideia da compaixão presente na personagem do subsolo é Vassoler, embora ele faça uma leitura da personagem do subsolo em uma perspectiva mais materialista. Vassoler argumenta que

o trecho acima grifado [referencia ao trecho de Memórias do Subsolo, no qual o homem do subsolo confessa à Liza que descarregou nela a ofensa recebida de seus colegas] diz mais sobre o que omite do que sobre aquilo que explicita. (...) Não foi por mero susto que o homem do subsolo deu seu endereço para Liza, não - foi por compaixão e solidariedade, porque ela também é uma humilhada e ofendida, porque ela ainda resguarda um ímpeto de superação em relação ao atual estado de coisas, ímpeto que a reificação do subsolo faz questão de deformar, mas cujo teor de verdade não pôde ser de todo extirpado. Só que, como já dissemos em nossa análise, o homem do subsolo, apesar de sentir os laivos da verdade, apesar de nutrir o ímpeto por comunhão, já não consegue acreditar na humanidade da amizade. Ele já não se sente apto para a vida pulsante, a vida 
viva, a vida que o subsolo aguilhoou. Assim, a sinceridade e a franqueza equivalem a uma despedida do convívio da pessoa que não pode ser sua companheira, mas apenas uma cúmplice ou pior, uma potencial delatora ${ }^{132}$

Um ponto importante que surge na obra e que deve ser considerado, porque reforça a condição de criatura do subsolo da narradora, é o título da obra. Ou melhor, é a falta de nome da personagem que nos dá mais um indício de sua especificidade. Assim como o narrador de Memórias do Subsolo, Niétotchka também se nos apresenta sem um nome, embora a mãe de Niétotchka a chame de “Ana”. Mas “Ana” de quê? É sabido que no século XIX para se ter um nome era fundamental ter um sobrenome. Uma coisa estava ligada a outra. No trabalho de Barbosa, podemos verificar esse ponto, que é trazido para pensar sobre a elaboração dessa personagem feminina. $\mathrm{O}$ autor explica que

envolvida pelo clima perturbador e miserável das 'pobres gentes', que o escritor procurara registrar desde o seu primeiro romance, Niétotchka Niezvánova (nome em que Boris Schnaiderman na 'Nota' que escreveu para a tradução de que eu cito, viu a intenção de Dostoiévski em deixar passar, já no nome, o sentido da humildade, uma vez que ambos ecoam significados prefixiais negativos, nada e não) $\log$ introduz o leitor no conhecimento de suas tensas relações familiares $[\ldots]^{133}$

Quem atenta também para essa questão da não nomeação de personagens é Kruger. Segundo ela

vale lembrar que o fato de as personagens não serem nomeadas reforça a leitura crítica que a obra incita [...] Nesse âmbito, destaca-se, por exemplo, a atuação complexa da dinâmica entre o indivíduo e o coletivo que o filme traz à reflexão, fazendo com que as discussões levantadas pelo filme, aparentemente no campo da intersubjetividade, devam também ser estendidas para toda uma coletividade. Consequentemente, não é por acaso a não nomeação das personagens - elas representam grupos, funções sociais: homens e mulheres; e, ao mesmo tempo, são historicamente estabelecidas: um núcleo familiar estadunidense, formado por dois intelectuais, situados na contemporaneidade. Logo, as questões erigidas pelos enunciados da forma e do conteúdo de Anticristo devem ser contemplados de uma forma dialética que dê conta da inter-relação entre o plano histórico e social, e o plano do indivíduo e de sua subjetividade, inclusive de sua construção psíquica. $^{134}$

132 Flávio R. Vassoler. Dostoiévski e a Dialética: Fetichismo da Forma, Utopia como Conteúdo. Tese. 2015. Pp. 115116.

133 João Alexandre Barbosa. A leitura do Intervalo. São Paulo. Iluminuras, 1990. P. 27.

134 Patrícia de Almeida Kruger. Penetrando o Éden: Anticristo, de Lars von Trier, à luz de Brecht, Strindberg e outros elementos inquietantes. Tese, 2016. P. 33. 
Dadas essas considerações de Kruger, voltemos às personagens do subsolo.

Já no início das Memórias, Dostoiévski se intromete e tece as seguintes considerações sobre o homem do subsolo: "pessoas como o seu autor [das Memórias] não só podem, mas devem até existir em nossa sociedade, desde que consideremos as circunstâncias em que, de um modo geral, ela se formou" ${ }^{135}$ A partir dessa intromissão do autor russo, fica-nos mais evidente o porquê da não nomeação do narrador personagem, Dostoiévski se dirige a um grupo que pode "até existir" naquela sociedade russa de então, o que corrobora as observações de Kruger. Em Niétotchka Niezvânova a questão surge de maneira mais esfumaçada, que sutilmente está colocada nesse título que nomeia a personagem ao mesmo tempo em que lhe nega o nome. Mas, vale ressaltar que esta obra está inserida nos anos de 1840, na mesma época da sombria existência do homem do subsolo que temos notícia por meio de suas memórias. Ou seja, ambos estão inseridos naquela realidade da Rússia de então.

E pensando ainda na realidade russa de 1840, é interessante observar como a própria fisionomia de São Petersburgo diz muito sobre esses homens de então. Atentemo-nos à expressão de Dostoiévski quando diz que devemos considerar "as circunstâncias em que ela [aquela sociedade russa do XIX] se formou". São significativas essas observações do autor russo ao localizar historicamente essa personagem do subsolo para compreendermos o efeito que também São Petersburgo exerce sobre esses homens de seu tempo.

Antoniasse, em seu trabalho sobre o homem supérfluo, de Turguêniev, traz uma questão que põe luz sobre o que está sendo proposto aqui, sobre a influência de São Petersburgo nos homens daquela época. Segundo o autor,

o maior símbolo dessa transformação cultural [processo de ocidentalização da Rússia] foi a construção da cidade de São Petersburgo, erguida para abrigar a nova capital do país e se constituir como 'uma janela para a Europa', em contraponto a Moscou, símbolo de tudo aquilo que a velha Rússia representava. ${ }^{136}$

Dadas essas considerações de Antoniasse, podemos ir mais além e não somente entendê-la como o maior símbolo daquela transformação cultural, mas, de alguma maneira, entendê-la (São Petersburgo) como um símbolo da cisão do homem de então. O próprio homem do subsolo tece considerações significativas sobre São Petersburgo.

[...] Para o uso cotidiano, seria mais do que suficiente a consciência humana comum, isto é, a

135 Nota de F. M. Dostoiévski na introdução de Memórias do Subsolo. Editora 34, 2000.

136 Samuel Junqueira Antoniasse. Diário de um homem supérfluo, de Turguêniev: caracterização de um tipo.

Dissertação. São Paulo. 2016. P. 76. 
metade, um quarto a menos da porção que cabe a um homem instruído do nosso infeliz século dezenove e que tenha, além disso, a infelicidade de habitar Petersburgo, a cidade mais abstrata e meditativa de todo o globo terrestre. (Dostoiévski: 2000, p. 18)

Pensemos, além disso, em como é simbólica a fisionomia de São Petersburgo aparecer em meio aos devaneios de Niétotchka. É como se a cidade pontuasse tal cisão no próprio homem. E, ao mesclar a sua fisionomia aos delírios infantis de Niétotchka, é como se o autor russo pontuasse que tipo de mentalidade está se desenvolvendo ali. 


\section{Considerações Finais}

Ao longo da pesquisa procuramos demonstrar como Niétotchka fala do seu subsolo. De início, demos atenção à questão da representação da mulher na literatura, valendo-nos de um estudo comparativo entre a nossa narradora e as personagens femininas do primeiro período de produção literária de Dostoiévski para obtermos aquilo que esperávamos mostrar: a diferença substancial em termos de elaboração artística de Niétotchka em relação às primeiras personagens femininas dostoievskianas. Para tal resultado foi de extrema importância discorrer sobre as implicações de tal elaboração artística, a qual projeta na literatura o conceito do que é o feminino, partindo de valiosas contribuições críticas que fizeram com que a questão da representação do universo feminino, ou aquilo que se entende como do universo feminino, pudesse dar conta de compreendermos, satisfatoriamente, o que estava implícito na elaboração de Niétotchka. Ou seja, evidenciar a ruptura do jovem Dostoiévski com ideias muito gerais e, sobretudo, artificiais sobre o que é o universo feminino.

Não percamos de vista o que foi e o que representou o Positivismo no século XIX, que teve como uma de suas implicações a manutenção da subserviência da mulher em relação aos homens, como discutido na primeira parte do trabalho.

Dostoiévski rompe ao representar Niétotchka, tirando-a desse "lugar comum" das mulheres, que tem como destino ser dona do lar, ser mãe e ser inevitavelmente subserviente ao marido, ou seja, ao homem. Como mostrado no primeiro momento da pesquisa, não vislumbramos essa tríplice função ter legitimidade na vida e na narrativa de Niétotchka. Procuramos mostrar, pela feitura da análise, uma mulher bem mais independente, em termos de elaboração, e, fundamentalmente, em termos de legitimidade de fala. Isso se dá, de maneira que a ausência do ponto de vista masculino na narrativa, como mostramos, na figura da não existência de um narrador em terceira pessoa, foi essencial para chegar ao efeito visado por Dostoiévski: representar, de maneira mais verossímil, a mulher.

Dada a relevância desse procedimento artístico na narrativa, fez-se necessário debruçar-se mais longamente sobre os estudos de gêneros no tocante à representação da mulher. No primeiro momento do percurso foi necessário problematizar tal questão da representação da mulher, uma vez que não somente Niétotchka será o centro da narrativa como, também, será a mediadora entre aquilo que é narrado e o leitor. Evidenciando, dessa forma, a maneira pela qual ela quer ser vista, ao contrário do que tínhamos (e temos) em termos de representação da mulher: um ponto de vista externo (na figura do narrador em terceira pessoa) que conduzia (e conduz) a maneira pela qual a mulher deve ser olhada.

Portanto, uma análise mais detida na pessoa que conduz a narrativa em Niétotchka Niezvânova, 
isto é, uma mulher, foi de extrema importância para pensarmos em como Dostoiévski teve a intenção de expor por meio da história de uma mulher a natureza ambígua do ser humano. Para refletirmos sobre essa intenção, lembremos que, quando da elaboração de Niétotchka Niezvânova, havia como seu subtítulo A História de uma Mulher. E, aqui, podemos fazer um paralelo, sem maiores prejuízos, com o nome inicialmente cogitado por Dostoiévski para Os Irmãos Karamazov, a saber, A História de um Grande Pecador. Não percamos de vista que, embora fosse muito jovem, Dostoiévski já tinha a ideia de fazer de Niétotchka Niezvânova um grande romance.

Niétotchka configurar-se-á, dado o grau de liberdade que Dostoiévski lhe atribuirá, como uma paradoxalista, tendo em vista o desenvolvimento de sua consciência em meio a tanta oscilação, o que, até então, era atributo de personagens masculinas. Também procuramos mostrar a oscilação de sentimentos em sua relação com o outro, postura típica das criaturas do subsolo. É emblemático na narrativa o seu desajuste social. Para além de uma questão de classe, verificamos a sua quase total falta de pertencimento ao mundo real. Aquilo que mais evidencia esse seu desajuste, como mostramos, é a relação de estranhamento entre Niétotchka e as crianças ao seu entorno.

Há, aqui nessa obra de 1840, a problematização do distanciamento do ser humano, na figura da nossa narradora. Esse estranhamento entre Niétotchka e as crianças dá-nos uma boa medida do seu caráter ambíguo. Niétotchka, assim como o homem cindido do subsolo, não se reconhece no outro, naquele que faz parte do mundo real, das amizades, das relações de proximidade. Niétotchka está sempre à parte, só se reconhecendo entre seus pares, à margem, que logo abaixo esclareceremos.

Esse não se reconhecer no outro da vida prática, da vida viva (já esboçado na personalidade da nossa narradora), nos leva inevitavelmente a uma questão maior, a qual será mais aprofundada na figura do homem do subsolo. Tal questão é o não reconhecimento de si mesmo, não se reconhecer como parte, mas como quem está fora e, portanto, não dentro daquela forma de sociabilização dos homens. Em Niétotchka isso se verifica, mais acentuadamente, na sua relação hostil com as crianças, com exceção de Kátia. E, num paralelo com o homem do subsolo, verificamos o total descompasso dele frente, por exemplo, aos colegas de repartição.

É exemplar aquela cena de Memórias do Subsolo, a cena de despedida do seu colega Zvierkóv, na qual o homem do subsolo tenta desesperadamente se convencer de sua superioridade em relação aos seus camaradas. Todavia, a cena é tão desastrosa e patética que o que se consegue vislumbrar é o desespero do homem do subsolo em ser aceito pelos seus colegas, o desespero de um homem que quer ser parte, que quer ser reconhecido, mas tudo o que consegue é se afundar, mais e mais, na sua própria interioridade de subsolo, ele está aquém do mundo objetivo que se torna hostil e o rebaixa ao grau mais alto da deploração humana, de criatura que está abaixo, de subumano, de criatura isolada.

Na cena, notamos como, até espacialmente, o personagem é colocado à margem, no momento 
em que as discussões chegam ao seu clímax, devido ao caráter arrogante e atrevido dele. Já neste momento de exaltação, os seus colegas de repartição se retiram para outro aposento, isolando-o, e ele passa a andar de um lado para o outro, durante três horas, sozinho e sem ser notado. Não é só pelo fiasco do encontro que vemos a sua deplorável situação como ser social, mas também pela própria estruturação da cena, que reitera o seu total descompasso com a vida objetiva.

As cenas de descompasso social de Niétotchka também são muitas. Pensemos, por exemplo, na cena em que Niétotchka vai morar na casa do Príncipe K. Com exceção do príncipe e de Kátia (mas esta bem mais adiante, porque também considerou em um primeiro momento a narradora uma criança estranha e muito pensativa), nenhuma das senhoras da casa simpatizam com Niétotchka. Trazemos, aqui, a questão (de grande importância) da marginalidade a que ela é também submetida na estruturação das suas cenas. Não nos esqueçamos que, nos últimos momentos da narrativa, em que ela se encontra na casa de Aleksandra Mikhailóvna, Niétotchka estará sempre encerrada na biblioteca, ou seja, sozinha. Esses espaços solitários são sempre a morada da narradora. E, consequentemente, das criaturas do subsolo.

Tudo isso é fruto de uma mente "hipertrofiada", que não ajusta as suas idéias ao mundo real das coisas e dos homens. O mundo que vislumbramos em Niétotchka Niezvânova é o mundo de suas fantasias e de suas idéias, embora essas últimas nem sempre expressadas, que dialoga com o mundo também apresentado em Memórias do Subsolo.

Assim como o homem do subsolo, Niétotchka está sempre passando de um polo ao outro no que diz respeito aos seus sentimentos e ao discurso apresentado, ainda que menos intensificado. No primeiro caso, é emblemática a sua relação com o padrasto, o que chamou a atenção do crítico Alexandre Barbosa, que vê ali um "revezamento de amor e ódio". Nota-se na relação com Iefimov, como vimos demonstrando, ora um sentimento de compaixão, ora um sentimento de presunção. Já no segundo caso, procuramos mostrar como a oscilação no discurso toma forma na relação de Niétotchka com a mãe. Ou melhor, no movimento de justificação de sua maldade para com a própria mãe que, como evidenciamos, não se justifica.

Não somente se verifica a sua natureza de subsolo pelas ambiguidades que surgem na sua narrativa (seja no tocante às suas relações com o outro ou no próprio discurso que a narradora constrói), que vimos mostrando nesse percurso, como também é de extrema importância pensarmos em como a própria estruturação da narrativa põe luz sobre o seu caráter de subsolo. Não é por uma mera casualidade que a narradora inicia suas reminiscências a partir de Iefimov. O que ocorre é que, propositadamente, Niétotchka se utiliza do outro para falar de si.

Se atentarmos para o caráter de seu padrasto, que é bem pontuado pelo relato da narradora, verificaremos que Iefimov é mais uma criatura do subsolo. O que explica, em certa medida, não somente as suas reminiscências se iniciarem com a história de vida de Iefimov como, 
principalmente, o fato da narradora dedicar três capítulos para falar dessa personagem. Quem atenta para esse ponto é Delfini, ao analisar o narrador de Um Romance Russo. Delfini cita Dominique Viart, quem acredita na ideia de que "algumas obras, desde os anos 1980, vêm recorrendo a uma narrativa do outro - do pai, da mãe, de outro ancestral - para falar de si [...]" ${ }^{137}$ A autora ainda afirma que

\begin{abstract}
o crítico propõe uma forma determinada da escrita de si, a saber, o récit de filiation. Nessa nova forma, que substituiria a autobiografia, troca-se a interioridade (interiorité) pela anterioridade (anteriorité), de modo que escrever sobre o outro torna-se 'um desvio necessário para chegar a si mesmo, para se entender nessa herança' ${ }^{138}$
\end{abstract}

Verificamos, pensando nas considerações de Delfini, que Niétotchka desvia de si a narrativa ao lançar mão da história e da personalidade de Iefimov com a finalidade, nesse desvio, de chegar a si mesma através do outro. E sobre essa herança, por assim dizer, deixada pelo padrasto, são significativas as primeiras palavras da narradora: "a marca deixada por ele [Iefimov] em minhas primeiras impressões de criança foi tão forte que influenciou o resto de minha vida”. Assim como se verifica também o quanto o menino Lária funciona como imagem no espelho da narradora, conforme já foi problematizado aqui. De acordo com a própria narradora: "foi Lária o escolhido para explicar toda a minha dor por intermédio da sua própria história”.

Isso posto, Lária e Iefimov funcionam nas reminiscências como imagens no espelho de Niétotchka. A narrativa é estruturada de tal maneira que, para colocar-se em foco, já que são as suas reminiscências, Niétotchka sutilmente se apresenta por meio do outro. Frank também chama a atenção para a psicologia parecida de ambos os personagens masculinos (Lária e Iefimov) ${ }^{139}$, psicologia sobre a qual Niétotchka se debruçará, corroborando a hipótese aqui apresentada.

Portanto, é por meio não somente da história de ambos os personagens masculinos, mas, sobretudo, por meio do caráter de Lária e Iefimov, que podemos chegar à natureza de subsolo da nossa narradora. Nesse sentido, vale observar a importância que Niétotchka dá ao caráter dessas personagens masculinas, como se ela se debruçasse sobre o seu próprio caráter. Assim sendo, podemos dizer que Niétotchka é a primeira mulher do subsolo em Dostoiévski.

E, finalmente, pensando ainda nesse período de produção da obra analisada, que foi discutido dentro de alguns limites no presente estudo, validando, inclusive, o percurso analisado aqui, façamos mais algumas considerações.

\footnotetext{
137 Mariana de Toledo Delfini. O narrador de "Um Romance Russo", de Emmanuel Carrère, e a promessa da autobiografia. São Paulo. Dissertação, 2016. P. 59.

138 Idem, ibidem.

139 Joseph Frank. Dostoiévski: As Sementes da Revolta, 1821-1849. São Paulo. Edusp, 2008. Ver p. 449.
} 
Embora a obra Memórias do Subsolo tenha sido publicada em 1860, a década de 1840 reverbera nessa obra. O próprio narrador das Memórias chama a atenção para tal fato nas suas reminiscências. E, como foi colocado ao longo da pesquisa, os círculos literários (que funcionavam, muitas vezes, como propagadores de ideias revolucionárias) que reuniam um número razoável de intelectuais da época, pelos quais o jovem Dostoiévski transitava, teve um papel fundamental na elaboração de suas obras. Isso, na medida em que não somente permitiu que ele se utilizasse daquelas novas ideias que surgiam na Rússia como material para a elaboração de sua prosa, como também serviu-lhe de parâmetro para questionar tais ideias de 1840.

Pensemos em Os Demônios, que claramente traz uma crítica feroz do autor russo à revolução, contrapondo-se, deste modo, radicalmente àquelas ideias que em 1840 fervilhavam na mente de muitos intelectuais russos. Inclusive, na mente do próprio Dostoiévski. Posto isso, foi importante na análise da obra aqui apresentada pontuar em qual momento histórico ela foi gerada, em que momento ela se situa. A ideia de romper com muitas questões de ordem política ou social era a praxe no momento da publicação de Niétotchka Niezvânova. Não foi uma mera casualidade o jovem escritor russo ter uma mulher no centro de sua primeira grande ideia de um romance.

A genialidade de Dostoiévski nessa obra está, como pudemos mostrar no percurso traçado, em inverter a idéia, culturalmente preservada, de quem é o transmissor dos anseios e das dúvidas humanas, o homem. É o homem que tem, historicamente, o respaldo da ciência, da cultura, da literatura como símbolo humano da capacidade de refletir e de ser o dono da palavra. Niétotchka surge, então, em termos de representação, dada a legitimidade de sua fala, como uma pessoa real, com todas as ambiguidades presentes na personagem feminina que são reflexos também do homem cindido do século XIX.

E se observarmos, mais atentamente, a galeria das personagens femininas dostoievskianas, veremos que o autor russo procurou representá-las da maneira mais verossímil possível, sem obscurecê-las com todos esses papéis pré-estabelecidos pela mentalidade masculina que, como mostramos, mais deforma do que representa a mulher. Conforme tudo aqui já exposto, esperamos que a presente pesquisa traga algumas reflexões acerca da construção literária das mulheres dostoievskianas e desse "subsolo" que é habitado, também, por elas. 


\section{Referências Bibliográficas}

AMÉRICO, Edelcio. “A Imagem Feminina de Moscou na Literatura Russa”. In: Revista Rus. São Paulo.

ANTONIASSE, Samuel Junqueira. Diário de um homem supérfluo, de Turguêniev: caracterização de um tipo. Dissertação. São Paulo, 2016.

ARIÈS, Phillipe. História Social da Criança e da Família. Rio de Janeiro. Zahar Editores, 1978.

AUERBACH, Erich. Mimesis. São Paulo. Editora Perspectiva, 2002.

BAKHTIN, Mikhail. Problemas da Poética de Dostoiévski. Rio de Janeiro. Forense Universitária, 2005.

Estética da Criação Verbal. São Paulo. Martins Fontes, 2003.

BARBOSA, João Alexandre. A leitura do Intervalo. São Paulo. Iluminuras, 1990.

BAUDELAIRE, Charles. O Pintor da Vida Moderna. Belo Horizonte. Autêntica Editora, 2010.

BERDIAEV, Nicolai. La Afirmación Cristiana y la Realidad Social Contemporánea. México.Ediciones Alba, 1936.

BERNARDINI, Aurora Fornoni. "Ideia e Sentimento". In: Revista Cult (Fiódor Dostoiévski O Profeta da Literatura Russa) n 4, p.23. Editora Bregantini.

. "Dostoiévski: Criação, Poesia e Crítica." In: Caderno de

Literatura e Cultura Russa, n. 2. Ateliê Editorial. São Paulo, 2008.

. "Questões de Forma e Modernidade em Gógol e Dostoiévski."

In: A Questão da Modernidade. DLM/FFLCH/USP. São Paulo, 1993.

BEZERRA, Paulo. “A Perenidade de Dostoiévski”. In: Revista Cult (Fiódor Dostoiévski O Profeta da Literatura Russa) n 4, p.13. Editora Bregantini.

. "Dostoiévski. As múltiplas facetas de uma obra". Fórum Nacional. Rio de

Janeiro, 2013.

BIANCHI, Fátima. “O Tema da Submissão Feminina na Novela Uma Criatura Dócil”. In: Caderno de Literatura e Cultura Russa, n. 2. Ateliê Editorial. São Paulo, 2008. . "Posfácio de A Senhoria". In: A Senhoria. São Paulo. Editora 34, 2006.

BRAIT, Beth. "O encontro privilegiado entre Bakhtin e Dostoiévski num subsolo". In: Revista eletrônica Bakhtiniana, nº 6. São Paulo, 2011.

BRANDÃO, Ruth Silviano. Mulher ao Pé da Letra: A Personagem Feminina na Literatura. B H, Minas Gerais. Ed. UFMG, 2006.

BUSHKOVITCH, Paul. História concisa da Rússia. São Paulo. Editora EDIPRO, 2014.

CAMARGO, Ana Maria Faccioli de. Sexualidade(s) e Infância (s): A sexualidade como um tema 
transversal. 1999.

CAMPOS, Alzira Lobo de Arruda; Gomes, Álvaro Cardoso; Godoy, Marília Gomes Ghizzi. O incesto na Literatura e na História. Rev. Humanidades, Fortaleza, v.31, n. 1. 2016.

CÂNDIDO, Antônio. “Os bichos do subterrâneo”. In: Tese e Antítese. Rio de Janeiro. Ouro sobre Azul, 2006.

CARVALHO, Marina Machado de. A Imagem e a Educação da Mulher no Positivismo: um estudo da condição feminina na filosofia de Auguste Comte. Dissertação. São Paulo, 1991.

CHKLOVSKI, V. "A Arte como Procedimento". In: Teoria da literatura: Formalistas russos. Porto Alegre: Globo, 1971.

. "Dostoiévski". In: Caderno de Literatura e Cultura Russa, n. 2. Ateliê Editorial.

São Paulo, 2008.

CRUZ, Talita Mochiute. "Notas sobre o anti-herói em Dostoiévski e em Beckett”. In: Dostoiévski e Bergman: o niilismo da modernidade. Editora Intermeios, 2012.

DOSTOIEVSKAIA, Ana Grigorievna. Meu Marido Dostoiévski. Rio de Janeiro. Mauad, 1999.

DOSTOIÉVSKI, Fiódor Mikháilovitch. Niétotchka Niezvânova. São Paulo. Editora 34, 2009. . Memórias Do Subsolo. São Paulo. Editora 34, 2000.

. Noites Brancas. São Paulo. Editora 34, 2005.

. Gente Pobre. São Paulo. Editora 34, 2009.

. A Senhoria. São Paulo. Editora 34, 2006.

FACCIN, Eni Izoleta. O Resgate da Coexistência Harmoniosa do Papel Masculino com o Feminino em “'O Grande Gatsby” de F. Scott Fitzgerald. São Paulo. 2001. Dissertação.

FERREIRA, Paulo Rogers. “A Criança Camponesa: Da ambiguidade ao permissível”. In: Cadernos CERU, série 2, v 21, $\mathrm{n}^{\circ} 1,2010$.

FILHO, Daniel Aarão Reis. As Revoluções Russas e o Socialismo Soviético. São Paulo.Editora UNESP, 2003.

FONSECA, Odomiro. Niilismo: Estrada para a emancipação. O destino Literário das Personagens Femininas Russas na Época das Grandes Reformas (1855-1866), 2017. Tese.

FOUCAULT, Michel. História da Sexualidade I: A Vontade de Saber. RJ. Edições Graal. 2001.

FRANK, Joseph. Dostoiévski: as sementes da revolta 1821-1849. Edusp, 2008.

. Dostoiévski: os efeitos da libertação 1860-1865. Edusp, 2002.

. Dostoiévski: os anos de provação 1850 a 1859. Edusp, 2008.

. Dostoiévski: os anos milagrosos 1865 a 1871. Edusp, 2013.

FREUD, Sigmund. Além do Princípio de Prazer - Psicologia de Grupo e Outros Trabalhos. Obras Completas, v. XVIII. RJ. Imago Editora, 1976.

. Fragmentos de Análise - Três Ensaios sobre a Teoria da Sexualidade e Outros 
Trabalhos. Obras Completas, v. VII. RJ. Imago Editora, 1989.

Obras Psicológicas Completas, v.XXI. 1974.

GROSSMAN, Leonid. Dostoiévski Artista. Rio de Janeiro. Civilização Brasileira, 1967.

HAUSER, Arnold. História social da arte e da literatura. São Paulo. Martins Fontes.1998.

JIMÉNEZ, José Antônio Hita. Nueva visión de la obra de Dostoiévsky. 2003.

JOSEF, Bella. "A mulher e o processo criador (a máscara e o enigma)”. In: Feminino Singular: a participação da mulher na literatura brasileira contemporânea. Edições GRD. São Paulo. Rio Claro, 1989.

KIRPÓTIN, V. I. "Dostoiévski”. In: Caderno de Literatura e Cultura Russa, n. 2. Ateliê Editorial. São Paulo, 2008.

KRUGER, Patrícia de Almeida. Penetrando o Éden: Anticristo, de Lars von Trier, à luz de Brecht, Strindberg e outros elementos inquietantes. São Paulo. Tese. 2016.

LAMEGO, Valéria. "Retrato de Senhora: A imagem da mulher brasileira na Pintura e Literatura do Século XIX”. In: IV Seminário Nacional: Mulher e Literatura. Abralic. Rio de Janeiro, 1992. LIMA, Rodrigo Ferreira de. Um Estudo da Personagem Feminina nos Contos de Tchékhov. São Paulo. 2012. Dissertação.

MARQUES, Priscila. Polifonia e Emoções: Um estudo sobre a construção da subjetividade em Crime e Castigo de Dostoiévski. São Paulo. 2010. Dissertação. . “A Condição Humana em Crime e Castigo". In: Caderno de Literatura e

Cultura Russa, n. 2. Ateliê Editorial. São Paulo, 2008.

MARTINS, Wilson. Prefácio “Dostoiévski como Romancista”. In: Nietótchka. José Olympio. Rio de Janeiro, 1952.

MAURO, Cláudia F. C. A Personagem Feminina na Narrativa de Alberto Moravia. São Paulo. 2001. Tese.

MIKHAILÓVSKI, Nicolai. “Um Talento Cruel”. In: Antologia do Pensamento Crítico Russo (1802-1901). Editora 34. São Paulo, 2013.

MILIOUKOV, Pavel Nikolaevich. Histoire de la Russie. Paris,1935.

MULVEY, Laura. "Prazer Visual e Cinema Narrativo". In: A Experiência do Cinema. Organizado por Ismail Xavier. Edições Graal. RJ, 1983.

NUNES, Natália. "Novelas da Juventude" e "Prólogo Geral". In: Obras Completas, VI. Rio de Janeiro. Ed. Nova Aguilar, 1995.

O' DWYER, Heitor. Os ensinamentos da loucura. A clínica de Dostoiévski: Memórias do Subsolo, Crime e Castigo, O Duplo. Editora Perspectiva. São Paulo, 2014.

OEHLER, Dolf. "Introdução" O Velho Mundo Desce Aos Infernos. Companhia das Letras. São Paulo, 1988. 
PAREYSON, Luigi. Dostoiévski Filosofia, Romance e Experiência Religiosa. São Paulo. Edusp, 2012.

PESSANHA, Rodolfo Gomes. Dostoiévski: ambiguidade e ficção. São Paulo, 1981.

PERRONE-MOISÉS, Leyla. “A multidão, o subsolo e a mansarda”. In: Fernando Pessoa, aquém do eu, além do outro. São Paulo. Martins Fontes, 2001.

PINTO, Manuel da Costa. "O criador de paisagens interiores". In: Cadernos entre Livros (Panorama da Literatura Russa) n ${ }^{\circ}$ 2, Duetto Editorial.

SANTOS, Nivaldo dos. "Posfácio de Noites Brancas". In: Noites Brancas. São Paulo. Editora 34, 2005.

SCHNAIDERMAN, Boris. Turbilhão e Semente. 1983. . Dostoiévski Prosa Poesia. São Paulo. Editora Perspectiva, 1982. . "Posfácio de Niétotchka Niezvânova". In: Niétotchka Niezvânova. São

Paulo. Editora 34, 2009.

. "Dostoiévski: a ficção como pensamento". In: ArtePensamento. São Paulo. Companhia das Letras, 1994.

SCHWARZ, Roberto. Um mestre na periferia do capitalismo. São Paulo. Livraria Duas Cidades, 1991.

SEGRILLO, Ângelo de Oliveira. Os Russos. São Paulo. Editora Contexto, 2012. . Rússia: Europa ou Ásia? Curitiba. Editora Prismas, 2016.

SHUR, Leonid A. Relações Literárias e Culturais entre Rússia e Brasil nos Séculos XVIII e XIX. São Paulo. Editora Perspectiva, 1986.

STEPÂNIAN, Karen. “Os Irmãos Karamázov: A Hosana de Dostoiévski”. In: Caderno de Literatura e Cultura Russa, n. 2. Ateliê Editorial. São Paulo, 2008.

TODOROV, Tzvetan. "Notas de um Subterrâneo”. In: Os Gêneros do Discurso. Martins Fontes, 1980.

TOLMATCHOV, Vassíli. "Histórico, Simbólico e Arquetípico: Dostoiévski versus Ibsen”. In: Caderno de Literatura e Cultura Russa, n. 2. Ateliê Editorial. São Paulo, 2008.

VÁSSINA, Elena. “A Poética do Drama na Prosa de Dostoiévski”. In: Caderno de Literatura e Cultura Russa, n. 2. Ateliê Editorial. São Paulo, 2008.

VASSOLER, Flávio Ricardo. Dostoiévski e a Dialética: Fetichismo da Forma, Utopia como Conteúdo. Tese. 2015. 